UNIVERSIDADE DE SÃO PAULO

FACULDADE DE MEDICINA DE RIBEIRÃO PRETO

PROGRAMA DE PÓS GRADUAÇÃO EM ONCOLOGIA CLÍNICA, CÉLULAS

TRONCO E TERAPIA CELULAR

RAFAEL DOS SANTOS

BEZERRA

APLICAÇÃO DE MÉTODOS DE BIOINFORMÁTICA PARA

IDENTIFICAÇÃO DE INFECÇÕES VIRAIS COM IMPACTO

EM HEMOTERAPIA

Ribeirão Preto - São Paulo 


\author{
UNIVERSIDADE DE SÃO PAULO \\ FACULDADE DE MEDICINA DE RIBEIRÃO PRETO \\ PROGRAMA DE PÓS GRADUAÇÃO EM ONCOLOGIA CLÍNICA, CÉLULAS \\ TRONCO E TERAPIA CELULAR
}

\author{
RAFAEL DOS SANTOS \\ BEZERRA
}

\title{
APLICAÇÃO DE MÉTODOS DE BIOINFORMÁTICA PARA IDENTIFICAÇÃO DE INFECÇÕES VIRAIS COM IMPACTO EM HEMOTERAPIA
}

Dissertação apresentada à Universidade de SãoPaulo (USP), Faculdade de Medicina de Ribeirão Preto, Ribeirão Preto, como parte das exigências para obtenção do título de Mestre emOncologia Clínica, Células-Tronco e Terapia Celular (Área de Conhecimento: Células Tronco e Terapia Celular)

Orientador(a): $\mathrm{Dr}^{\mathrm{o}}$ Svetoslav Nanev Slavov

Bolsista: Fundação de Amparo à Pesquisa do Estado de São Paulo - Brasil (FAPESP) Processo 2019/08528-0

Ribeirão Preto - São Paulo 
Autorizo a reprodução e divulgação total ou parcial deste trabalho, por qualquer meio convencional ou eletrônico, para fins de estudo e pesquisa, desde que citada a fonte.

Bezerra, Rafael dos Santos

Aplicação de métodos de bioinformática para identificação

de infecções virais com impacto em hemoterapia, 2021.

100 p. : il. ; $30 \mathrm{~cm}$

Dissertação de Mestrado, apresentada à Faculdade de Medicina de Ribeirão Preto/USP. Área de concentração: Células Tronco e Terapia Celular.

Orientador: Slavov, Svetoslav Nanev.

1. Bioinformática. 2. Viroma. 3. Metagenômica. 4. Hemoterapia. 5. Segurança tranfusional. 
RAFAEL DOS SANTOS

BEZERRA

\section{APLICAÇÃO DE MÉTODOS DE BIOINFORMÁTICA PARA IDENTIFICAÇÃO DE INFECÇÕES VIRAIS COM IMPACTO EM HEMOTERAPIA}

Dissertação apresentada à Universidade de SãoPaulo (USP), Faculdade de Medicina de Ribeirão Preto, Ribeirão Preto, como parte das exigências para obtenção do título de Mestre emOncologia Clínica, Células-Tronco e Terapia Celular (Área de Conhecimento: Células Tronco e Terapia Celular)

Orientador(a): Dr ${ }^{\mathrm{o}}$ Svetoslav Nanev Slavov

Aprovado em:

\section{BANCA EXAMINADORA}

Dr. Svetoslav Nanev Slavov

Dr. Antonio Charlys da Costa

Dr. José Eduardo Levi 
"O presente trabalho foi realizado com apoio da Fundação de Amparo à Pesquisa do Estado de São Paulo - Brasil (FAPESP) - Processo 2019/08528-0”.

"O presente trabalho foi realizado com apoio da Coordenação de Aperfeiçoamento de Pessoal de Nível Superior - Brasil (CAPES) - Código de Financiamento 001". 


\section{AGRADECIMENTOS}

Neste longo caminho de percalços e aprendizado que foi meu mestrado tenho que agradecer enormemente ao apoio dada pela minha família, agradeço a minha mãe Maria Aparecida dos Santos por todo apoia e incentivo, agradeço aos meus avós Maria Mara Paião e Francisco Paião, minhas irmãs Mariana do Santos Reis e Daniela dos Santos Ruiz e minha namorada Camila Yamashita, todos responsáveis por me fazerem chegar até aqui e concluir essa etapa tão importante em minha vida. Agradeço aos companheiros de laboratório que contribuíram para meu enormemente ao meu crescimento científico, João Paulo Ximenez, Carlos Biagi, Ricardo Nociti, Marcelo Gomes e Raphael Morraye e a todos meus amigos de graduação e de fora do meio científico. Agradeço ao meu orientador Dr. Svetoslav Nanev Slavov por ter sempre somado em todos os aspetos possíveis e ter desenvolvido minhas habilidades como pesquisador. Agradeço o Hemocentro de Ribeirão Preto e a Faculdade de Medicina de Ribeirão Preto em especial na figura do Prof. Dr. Dimas Covas por todos o aporte dado para execução de minha pesquisa e desenvolvimento pessoal. Agradeço ao Leonardo Scalon de Oliveira pelos dados cedidos para pesquisa, Edson Lara de Morreto pelas amostras de doença pós doação, ao Laboratório de biologia molecular em especial a Dra. Simone Kashima pelo uso da infraestrutura e aporte intelectual. Agradeço ao Instituto de Pesquisa do Câncer de Guarapuava - PR, em especial ao Prof. Dr. Wilson de Araújo e Dra. Kamila Peronni pela estrutura para realizar as atividades de sequenciamento de nova geração. Ao AC de Camargo em especial para Bruna Durães de Figueiredo Barro pela execução do sequenciamento de nova geração. Ao Instituto de Hematologia e Hemoterapia do Amapá em especial á Hellen Tayaná Bitencourt pelas amostras de pacientes infectados por doenças parenterais. Ao Hospital Astrogildo de Azevedo - RS em especial a Dra. Ana Zimmermann pelas amostras de pacientes infectados por doenças parenterais. Ao Hospital Israelita Albert Einstein pela doação de amostras em especial á Ana Carolina Bonet Bub, Sanny Marcele Costa Lira e Mauro Kutner. Ao Ministério da Saúde na figura de Vagner Fonseca pela ajuda nas análises bioinformáticas. Ao Instituto Pasteur - França em especial ao Dr. Mathias VanDerBogart e a Dra. Valerie Caro pela implementação inicial das análises bioinformáticas. Por fim ao 
Instituto Nacional de Transfusão de Sangue - França em especial a Dra. Virginie Sauvage e a Dra. Syria Laperche pela implementaão do sequenciamento de nova geração em nosso laboratório. 
BEZERRA, Rafael dos Santos. Aplicação de métodos de bioinformática para identificação de infecções virais com impacto em hemoterapia. 2021. 98 f. Dissertação de Mestrado Faculdade de Medicina de Ribeirão Preto, Universidade de São Paulo, Ribeirão Preto, 2021.

\section{RESUMO}

Com a chegada de novas tecnologias de sequenciamento, como as de segunda e terceira geração, o tempo e custo das análises reduziram drasticamente enquanto a obtenção de dados aumentou significativamente. Desta maneira, ampliou-se a utilização dessas novas metodologias possibilitando diversas aplicações. Dentre essas aplicações podemos destacar a metagenômica. A metagenômica consiste na obtenção do material genético detodos os organismos presentes em uma única amostra, seja ela ambiental ou clínica. O viroma é uma área da metagenômica em que o foco são os vírus encontrados nestas amostras. Dentre as possíveis aplicações da análise do viroma está a identificação de vírus emergentes e re-emergentes com impacto na área de hemoterapia. Para isso aplicamos técnicas de identificação do viroma em bolsas de sangue com Doença Pós-Doação (DPD) relatada pelo doador (geralmente sintomas relacionados a infecção) febre, exantema, conjuntivite, dores retro orbitais, artralgia, mialgia, diarreia, vômitos, enjôo) e amostras de doações de sangue obtidas de doadores positivos para infecções rotineiramente triadas nos bancos de sangue da região norte (Macapá, Amapá) e sul do país (Santa Maria, Rio Grande do Sul). Para isso foi implementada uma pipeline bioinformática de alto rendimento para identificação de vírus emergentes e re- emergentes. A implementação foi realizada em BASH script, DOCKER (containers) e alguns PERL scripts desenvolvidos inhouse. Dentre os principais passos executados podemos citar o controle de qualidade das sequências com o software FastQC, limpeza das sequências de baixa qualidade e caudas poli-x com Trimmomatic e AfterQC, montagem dos genomas com o software SPAdes e finalmente classificação taxonômicas das sequências com Kraken2 e Diamond. As análises filodinâmicas dos vírus encontrados e com genoma recuperado foram feitas através dos softwares IQ-TREE e do pacote BEAST. Dentre nossos resultados das amostras com DPD de Ribeirão Preto podemos destacar o primeiro 
relato do vírus da Influenza A (H2N3) em amostras de plasma de doadores de sangue. Assim como também identificamos o vírus da Dengue e Parvovírus B19 (todos sem testagem obrigatória). Interessantemente em amostras provenientes da região norte do país encontramos o pouco conhecido Gemykibivírus humano-2, um vírus relacionado a quadros clínicos graves e coinfecções com HIV. Outro achado interessante nestas amostras foi o Merkell cell poliomavírus com genoma completo recuperado (o que podeindicar um estado viremico). No Brasil, até então não foram desenvolvidos estudos abrangentes sobre infecções emergentes com impacto na transfusão de sangue e a sua ameaça real para os processos hemoterápicos é subestimada e pouco conhecida. Porém há alguns desafios neste âmbito a serem superados, dentre eles podemos citar as análises bioinformáticas dos dados gerados, que demanda muitas vezes altos recursos computacionais e mão de obra especializada. Portanto, este estudo visa investigar o impacto das viroses emergentes e não suspeitas na área da hemoterapia utilizando sequenciamento de última geração e a implementação de um pipeline bioinformática eficiente para análise do viroma.

Palavras chaves: Metagenômica, Viroma, SNG, pipeline bioinformática, hemoterapia, vírus emergentes, vírus reemergentes, doença pós-doação, DPD 
BEZERRA, Rafael dos Santos. Application of bioinformatics methods to identify viral infections with impact on hemotherapy. 2021. 98 f. Master's Dissertation - Ribeirao Preto Medical School, University of São Paulo, Ribeirao Preto, 2021.

\section{ABSTRACT}

With the introduction in the laboratory practice of new sequencing technologies, like second and third generation techniques, the time and cost of the sequencing has drastically reduced while the generated data has increased significantly. In this way, the field of application of these new techniques has expanded incliding analysis of the microbial communities of clinical and environmental samples known as metagenomics. Virome isan important area of metagenomics where the focus is concentrated on the viruses foundin these samples. Among the possible applications of virome analysis is the identification of emerging and re-emerging viruses which can impact the area of hemotherapy. To investigate these agents, we applied virome techniques in blood units obtained from donors who related with Post-Donation Disease Reports (PDDR) (including symptoms like fever, rash, conjunctivitis, retro-orbital pain, arthralgia, myalgia, diarrhea, vomiting, and nausea among others). We also applied viral metagenomics to blood donations obtained from high-risk blood donors from Northern and Southern Brazil. To do this, ahigh-performance bioinformatics pipeline was implemented to identify emerging and re- emerging viruses. The implementation was carried out in BASH script, DOCKER (containers) and in-house developed PERL scripts. The main stages of the pipeline include quality control of the sequences with the FastQC software, cleaning of low-quality sequences and poly-x tails by Trimmomatic and AfterQC, genome assembly by SPAdes software and finally sequence taxonomy using Kraken2 and Diamond. The phylodynamic analyzes of the most important viruses found were performed using the IQ-TREE software and the BEAST package. Among our results from PDDR samples we can highlight the first report in the literature of the Influenza A virus $(\mathrm{H} 2 \mathrm{~N} 3)$ in plasma samples from blood donors. We also identified the dengue virus and Parvovirus B19 (both not included in the route testing of the blood collection services). Interestingly, in samples from North Brazil, we identified in high-risk blood donors the scarcely studied studiedHuman Gemykibivirus-2, which has already been related to severe clinical conditions and HIV co-infections. Another interesting finding in these samples was the Merkell cell polyomavirus with high sequence numbers (which may indicate a viremic state). In Brazil, comprehensive studies on infections which can impact transfusion safety have not been performed and the real impact of the emerging viruses on the hemotherapy processes is underestimated and little known. However, some challenges in this area must 
be overcame, and among them we can mention the bioinformatics analysis of the generated data, which often requires high computational resources and specialized labor. Therefore, our study examines in extensive manner the impact of emerging viruses in the area of hemotherapy using the newest sequencing generation and implementing an efficient bioinformatics pipeline for virome analysis.

Keywords: Metagenomics, Viroma, NGS, bioinformatics pipeline, hemotherapy, emerging viruses, reemerging viruses, postdonation disease reports, PDDR 


\section{LISTA DE FIGURAS}

Figura 1. Descrição das diferentes gerações de sequenciadores utilizados no mercado de genômica tradicional. Podemos dividir em sequenciadores de primeira geração como o Sanger que tem capacidade de gerar até mil pares de bases, os de segunda geração como o 454, Ion Torrent e Illumina que podem gerar de 50-500 pares de bases, sendo assim considerados geradores de sequencias curtas. Em suma temos os sequenciadores de terceira geração como o Oxford Nanopore e PacBio conhecidos por geração de sequencias contínuas de até 1000 pares de base, portanto são conhecidos como sequenciadores de terceira geração .

Figura 2. Sequenciador de peptídeos automatizado de Edman. Este foi um dos primeiros sequenciadores de peptídeos automatizado desenvolvido por William J. Dreyer. Adapatado de Gauthier, J et al., 2018

Figura 3. Gráfico de controle de qualidade gerado pelo software FastQC. No eixo Y podemos verificar a pontuação de qualidade dos dados, no eixo $\mathrm{X}$ se encontra o tamanho médio das sequencias analisadas. A linha azul corresponde a qualidade média por pares de base em determinado comprimento da sequência

Figura 4. Utilização de k-mers na classificação taxonômica das sequencias processados e na montagem do genoma por sobreposição dos fragmentos. Neste exemplo temos uma sequência de 17 nucleotídeos que para ser processada foi quebrada em fragmentos menores de 7 nucleotídeos ou seja $\mathrm{k}=7$ (7-mers).

Figura 5. Avaliação do sinal filogenético pelo software TREE-PUZZLE. A) Nível de saturação. O nível de saturação está diretamente ligado ao tamanho das sequencias inclusas no dataset, ou seja, quanto menor a sequência maior a saturação e menor será o sinal filogenético encontrado. B) Mapeamento de máxima verossimilhança. A soma dos 3 valores nas extremidades do triangulo tem que ser superior a $60 \%$ para se ter um sinal confiável. O valor encontrado ao centro é relativo à porcentagem de árvores não resolvidas e os valores laterais são relativos as árvores resolvidas. A probabilidade de resolução está diretamente ligada ao nível de saturação do dataset. Adaptado de Schmidt, H.A et al., (2002).....

Figura 6. Modelos de relógio molecular estrito e relaxado. Além de padrões de modelagem populacional o BEAST leva em consideração a variação da taxa evolutiva em relação tempo/espaço, desta maneiro no caso dos vírus que sofrem uma alta taxa de mutação em curtos períodos o modelo de relógio molecular mais indicado seria o relaxado. Adaptado de Suchard, MA et al., 2018

Figura 7. Pipeline utilizada inicialmente para o processamento dos dados de metagenômica. Os dados gerados inicialmente passam por um controle de qualidade, limpeza das sequencias de baixa qualidade e descontaminação de DNA do hospedeiro. Posteriormente essas sequencias são classificadas e montadas em sequencias maiores (contigs ou genoma completo). Por fim passam para as análises filodinâmicas para entender o comportamento epidemiológico dos vírus encontrados

Figura 8. Pipeline nova utilizada para o processamento dos dados de metagenômica. Os dados gerados inicialmente passam por um controle de qualidade, limpeza em duas etapas das sequencias de baixa qualidade e um controle de qualidade final. Posteriormente essas sequencias são classificadas e montadas em sequencias maiores (contigs ou genoma completo). Por fim passam para as análises filodinâmicas para entender o comportamento epidemiológico dos vírus encontrados

Figura 9. Análise filogenética do Dengue vírus 2 (DENV2). Apenas genomas completos foram utilizados para análise filogenética. O modelo de substituição de nucleotídeos utilizado foi o TIM2+F+G4 para a reconstrução da árvore, escolhido pelo modelo estatístico BIC (Critério de Informação Bayesiano), utilizando 10.000 réplicas de bootstrap ultrarrápidas para suporte estatístico dos ramos. Apenas valores acima de $75 \%$ foram demonstrados nos ramos da árvore. 
A árvore filogenética foi construída usando o software IQtree v.16.12, aplicando-se a abordagem de máxima verossimilhança...

Figura 10. Árvore de credibilidade máxima do clado demonstrando as relações filogenéticas dos 96 genomas do Dengue vírus 2. Análise filogeográfica foi conduzida com o pacote BEAST versão 1.10.4, apenas probabilidades posteriores acima de 0.99 estão representadas nos ramos por círculos em vermelho

Figura 11. Análise filogenética do Dengue vírus 2 (DENV2). Apenas genomas do envelope foram utilizados para análise filogenética. $\mathrm{O}$ modelo de substituição de nucleotídeos utilizado foi o $\mathrm{TN}+\mathrm{F}+\mathrm{I}+\mathrm{G} 4$ para a reconstrução da árvore, escolhido pelo modelo estatístico BIC (Critério de Informação Bayesiano), utilizando 10.000 réplicas de bootstrap ultrarrápidas para suporte estatístico dos ramos. Apenas valores acima de $75 \%$ foram demonstrados nos ramos da árvore, valores mais próximos ou iguais a 100 se aplicam a cor vermelha, valores mais próximos ou iguais 75 se aplicam a cor azul. A árvore filogenética foi construída usando o software IQtree v.16.12, aplicando-se a abordagem de máxima verossimilhança .....

Figura 12. Árvore filogenética de máxima verossimilhança da hemaglutinina (A) e neuraminidase (B) do vírus influenza A (H3N2) detectado em doação de sangue. A cor verde indica a cepa H3N2 obtida do doador de sangue de Ribeirão Preto; diamantes em cada nó indicam suporte estatístico ao longo dos ramos definidos com bootstrapping ultra-rápido $>90 \%$ (de 10.000 réplicas). O cluster onde está localizada a cepa obtida de Ribeirão Preto é mostrado em detalhes na parte inferior.

Figura 13. Análise filogenética do Parvovírus humano B19. Apenas genomas completos foram utilizados para análise filogenética. O modelo de substituição de nucleotídeos utilizado foi o $\mathrm{TN}+\mathrm{F}+\mathrm{R} 2$ para a reconstrução da árvore, escolhido pelo modelo estatístico BIC (Critério de Informação Bayesiano), utilizando 10.000 réplicas de bootstrap ultrarrápidas para suporte estatístico dos ramos. Apenas valores acima de $75 \%$ foram demonstrados nos ramos da árvore. A árvore filogenética foi construída usando o software IQtree v.16.12, aplicando-se a abordagem de máxima verossimilhança...

Figura 14. Identificação do Gemykibivirus-2 humano em amostras de doadores de sangue da Amazônia com infecções parentéricas. A. Localização geográfica da cidade de Macapá, no estado do Amapá, na Amazônia brasileira. B. Eletroforese em gel das três amostras positivas obtidas de doadores de sangue da Amazônia (AP3, AP8 e AP14). Outras abreviações: M, escada molecular; $\mathrm{B}$, amostra em branco e $\mathrm{C}+$, controle positivo. $\mathrm{C}$. Análise filogenética do gemykibivirus-2 humano (HuGkV-2). O modelo de substituição nucleotídica utilizado foi o $\mathrm{HKY}+\mathrm{F}+\mathrm{R} 5$ para reconstrução da árvore e foi escolhido de acordo com o modelo estatístico BIC (Critério de Informação Bayesiano), utilizando 10.000 réplicas de ultrafast bootstrap para significância estatística. Apenas valores acima de 75\% são demonstrados nos ramos da árvore.

.65

Figura 15. Árvore filogeográfica de diferentes isolados do Merkel cell poliomavírus. Ao total utilizamos 115 cepas para descrever a trajetória temporal/geográfica do vírus até nossa cepa. A foi gerada em escala temporal usando o programa BEAST v.1.10.2, com o modelo de substituição HKY $+4 \mathrm{G}$ mais modelo de coalescência bayesiana skygrid. Em destaque temos o clado onde se encontra o nosso isolado. O suporte estatístico é demonstrado nos ramos da árvore.

Figura 16. Mapa de calor baseado em divergência populacional. Podemos verificar que o nosso isolado destacado pela seta vermelha segue o padrão das maiorias das cepas encontradas na américa do sul ou seja tendem a ter a mesma origem geográfica possivelmente europeia e as cepas de possível origem africana em minoria se destacam no mapa com maior densidade

Figura 17. Gráfico de barras ilustrando a abundância relativa e absoluta de vírus encontrados nos pools testados de amostras de plasma. No eixo dos X é expresso o número de pools testados: A) Abundância relativa de vírus encontrados nos pools analisados; B) Abundância absoluta em relação ao número de leituras virais encontradas nos pools testados. A alta abundância do Vírus iridescente de invertebrados 6 pode ser observada no pool número 07 , ao qual pode ser atribuída uma transmissão passiva dos mosquitos vetores circulantes durante o surto de arbovírus testado. 


\section{LISTA DE TABELAS}

Tabela 1. Amostras clínicas de doença pós-doação obtidas de doadores relatando DPD do Hemocentro de Ribeirão Preto/São Paulo, do ano epidemiológico de 2019

Tabela 2. Amostras clínicas de doença pós-doação pertencentes a cidade de Ribeirão Preto/São Paulo, do ano epidemiológico de 2016

Tabela 3. Amostras clínicas de doença pós-doação pertencentes a cidade de São Paulo/São Paulo, do ano epidemiológico de 2016

Tabela 4. Amostras clínicas de doadores de alto risco pertencentes a cidade de Macapá/Amapá, do ano epidemiológico de 2019/2020

Tabela 5. Amostras clínicas de doadores de alto risco pertencentes a cidade de Santa Maria/Rio

Grande do Sul, do ano epidemiológico de 2019/2020

Tabela 6. Representação dos pools analisados. Na tabela podemos verificar os vírus encontrados em cada pool assim como a quantidade de sequências recuperadas e contigs máximos formados.

Tabela 7. Representação dos pools analisados. Na tabela podemos verificar os vírus encontrados em cada pool assim como a quantidade de sequências recuperadas e contigs máximos formados. 


\section{SUMÁRIO}

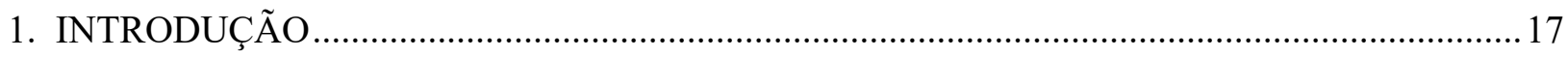

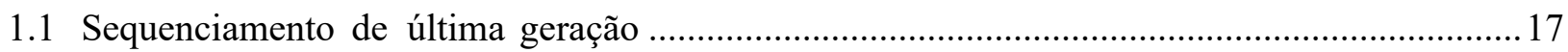

1.2 Aspectos históricos da metagenômica............................................................................ 19

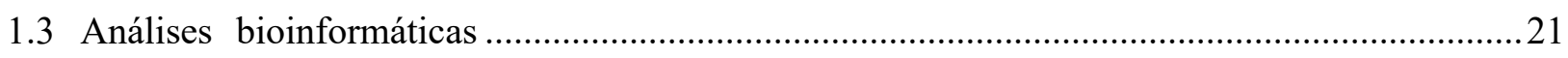

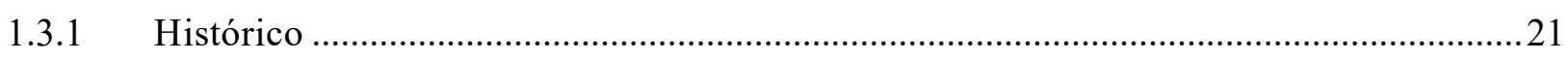

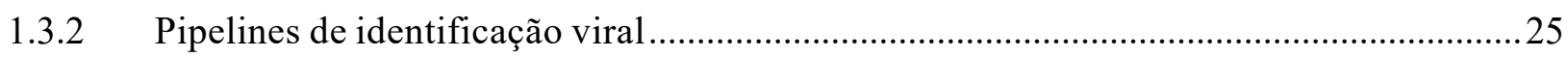

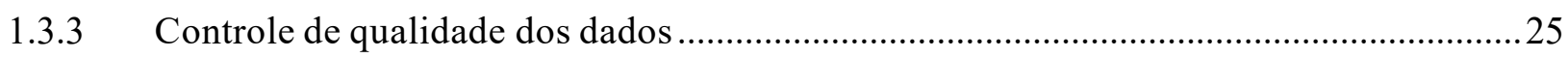

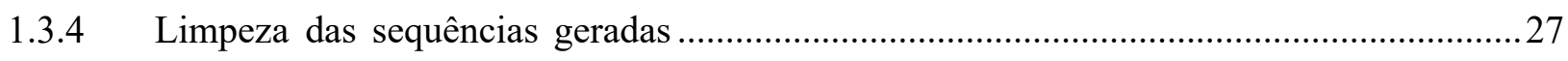

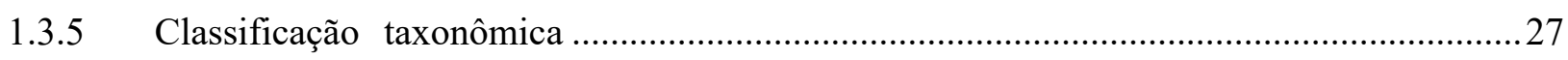

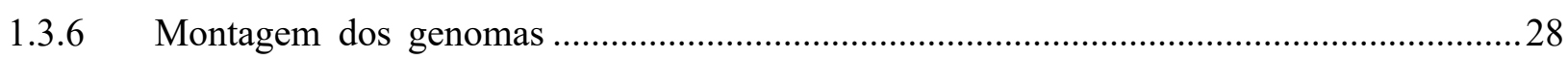

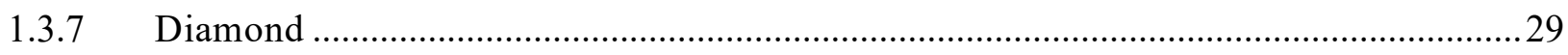

1.4 Principais problemas encontrados nas análises bioinformáticas ........................................29

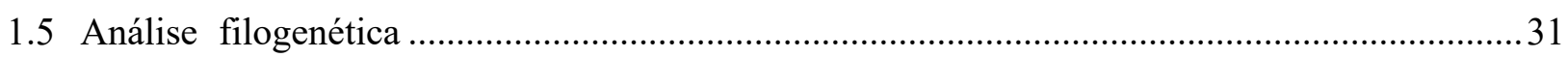

1.6 Utilização da metagenômica na identificação de agentes patogênicos e seuimpacto na área

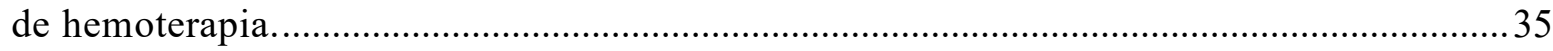

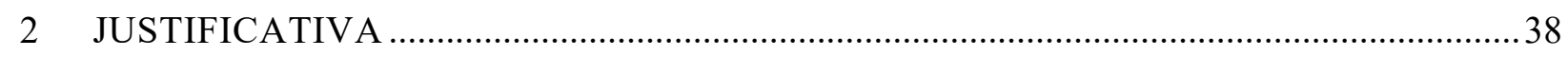

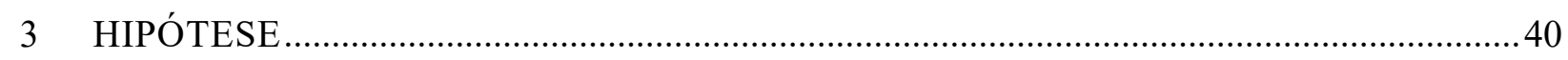

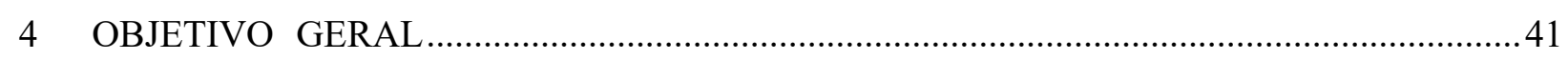

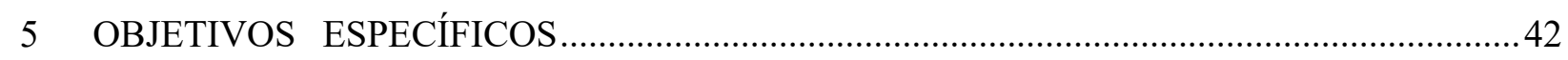

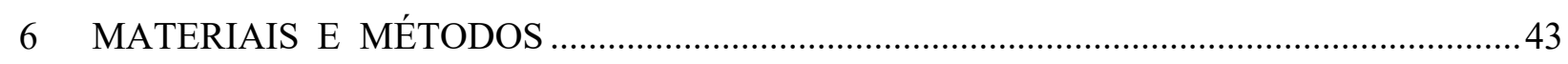

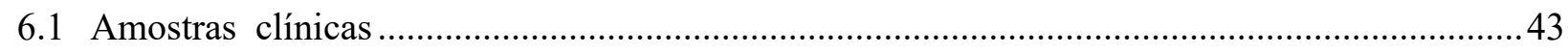

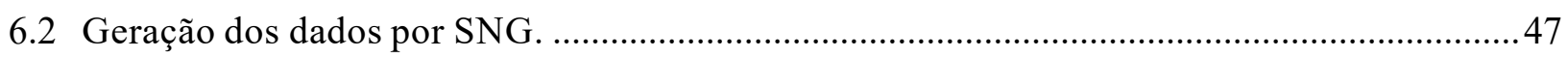

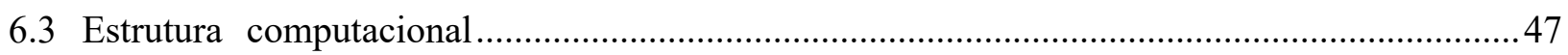

6.4 Pipeline utilizada inicialmente (introdução pela equipe do Instituto Pasteur)....................... 48

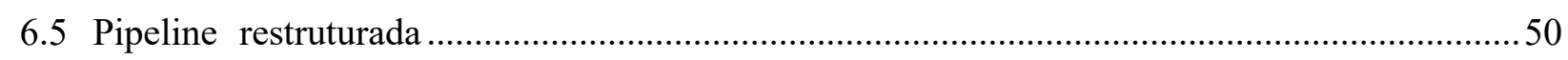

6.6 Análise filogenética, filogeográfica e relógio molecular.........................................................51

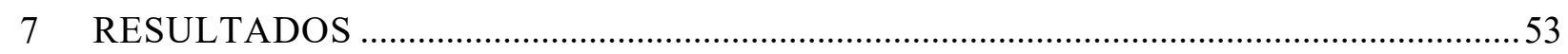

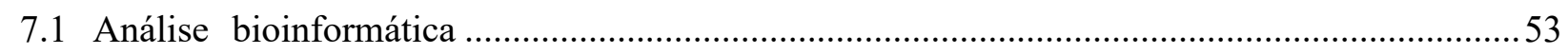

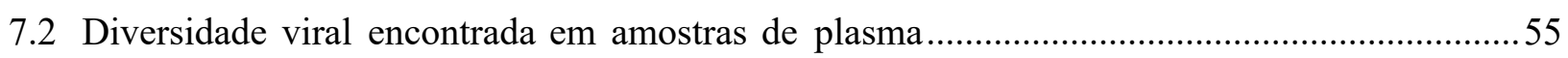

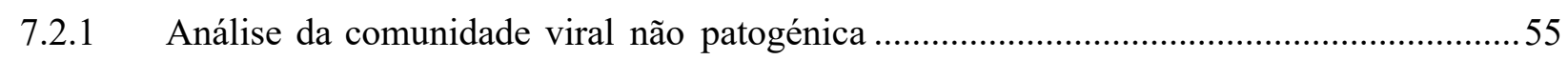

7.2.2 Análise bioinformática de Amostras clínicas de doença pós-doação obtidasde doadores relatando DPD do Hemocentro de Ribeirão Preto/São Paulo,do ano epidemiológico de $2019 / 2020$ 
7.2.3 Análise metagenômica de bolsas de sangue provenientes de doadores infetados com HIV, HBV, HCV, HTLV, doença de Chagas e sífilis da regiãoAmazônica

7.2.4 Estudos sobre pools de Ribeirão Preto obtidos durante surto de ZIKV/DENV em 2019

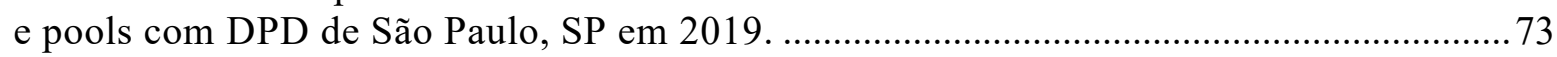

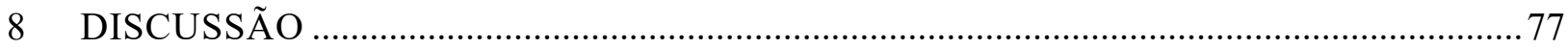

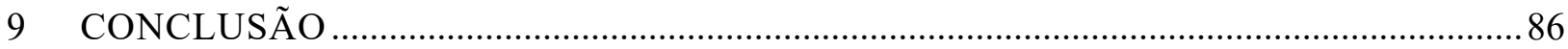

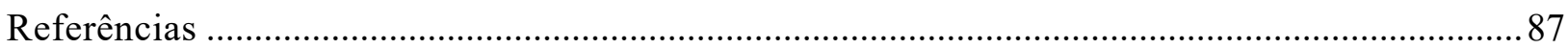




\section{INTRODUÇÃO}

\subsection{Sequenciamento de última geração}

Em 1977, Fred Sanger e Alan R. Coulson, revolucionaram o mundo apresentando ao público uma metodologia para se obter informações sobre as moléculas de DNA. O método denominado sequenciamento de Sanger se manteve por décadas, inclusive foi utilizado para o sequenciamento do genoma humano em um projeto revolucionário para época (HEIDI, 2008).

Porém com o rápido avanço da tecnologia, ele foi substituído pelos aparelhos de sequenciamento de nova geração ( $\mathrm{SNG})$, que tem uma capacidade de processamento de dados muito mais elevada em relação ao seu antecessor, permitindo uma análise global e robusta (WOLD e MYERS, 2007). Com isso o tempo de sequenciamento e a mão de obra necessária caiu drasticamente, como exemplo podemos citar o próprio genoma humano que demorou anos e envolveu milhares de pessoas. Hoje com o SNG pode ser feito por uma pessoa em horas. Um dos grandes diferenciais que podemos citar é a alta capacidade de geração de dados sequenciais a um custo relativamente baixo (ZHONG, GERSTEIN e SNYDER, 2009).

As tecnologias de SNG disponíveis no mercado compreendem sequenciadores de segunda e terceira geração, sendo os de segunda geração mais amplamente utilizados incluindo MiSeq/NextSeq 550/1000/2000 e o mais recente NovaSeq 6000 da Illumina e o Ion Proton da Ion Torrent (Life Technologies) (Illumina). Mesmo essas plataformas trabalhando de forma distinta apresentando tecnologias de detecção diferenciadas, o fluxo de trabalho de sequenciamento é baseado na preparação de suas bibliotecas genômicas para produção de clusters que são sucessivamente clonados e sequenciadas em uma maneira massiva (LINLIN et al., 2012).

Há algumas diferenças no processo de sequenciamento das duas tecnologias. O Ion Proton tem como conceito geral a realização do sequenciamento por detecção de sínteses eletroquímica, (LEAMON e ROTHBERG, 2007), onde há um processo o desprendimento de íon hidrogênio $(\mathrm{H}+)$ (MERRIMAN, ION TORRENT R\&D TEAMe ROTHBERG, 2012; BAUSELlS et al., 1999). Por outro lado, a técnica Illumina, adota um sistema de sequenciamento por fluorescência e síntese. A biblioteca é gerada por adaptadores fixos que são postos em uma flowcell, seguida de 
amplificação em pontes para formar bibliotecas que contêm fragmentos de DNA clonal (MARDIS 2008; LIN et al., 2012). Porém com o passar dos anos podemos verificar uma melhora considerável e uma precisão cada vez mais alta dos equipamentos de sequenciamento. Dentre os diferentes modelos existentes de SNG disponíveis no mercado destaca-se o Illumina NextSeq 550. Este aparelho bastante utilizado no mercado mundial devido ao baixo custo, alta cobertura, gerando sequencias curtas com até 300 pb, (EID et al., 2009; LI et al., 2014). Em comparação com o Ion Torrent que é capaz de gerar leituras mais longas que o Illumina, Ion Torrent apresenta entrada de dados reduzida, assim gerando uma maior taxa de erros (REUTER, DAMEK e SNYDER, 2015).

Os sequenciadores de terceira geração como o PacBio e Nanopore produzem leituras muito mais longas. No entanto, mesmo com signficativas melhorias estas plataformas ainda possuem alta taxa de erros intrínsecos $(\sim 10 \%)$ e para obter dados relevantes apresentam custo mais alto comparados com a plataforma Illumina. (REUTER, DAMEK e SNYDER, 2015). Entretanto o que chama atenção nas técnicas de SNG independente da tecnologia envolvida são as possibilidades de atuação dessas plataformas, uma dessas possibilidades é a metagenômica que se encontra em crescente utilização e vem se demonstrando um eficiente método para diagnóstico e entendimento entre interações ambiente/microrganismos. Abaixo destacam-se as principais plataformas de sequenciamento de diferentes gerações disponíveis no mercado (Figura 1). 

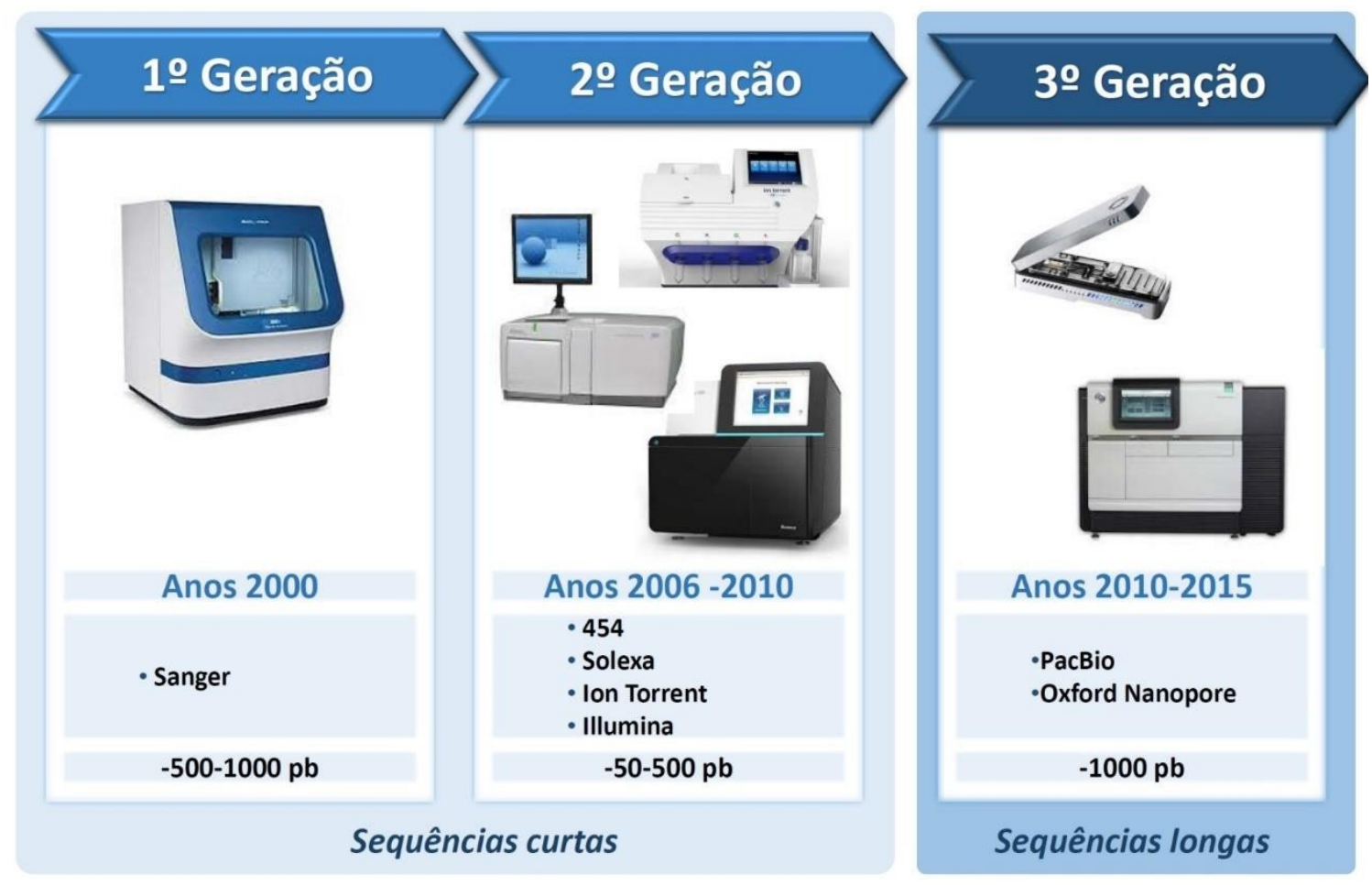

Figura 1. Descrição das diferentes gerações de sequenciadores utilizados no mercado de genômica tradicional. Podemos dividir em sequenciadores de primeira geração como o Sanger que tem capacidade de gerar até mil pares de bases, os de segunda geração como o 454, Ion Torrent e Illumina que podem gerar de 50-500 pares de bases, sendo assim considerados geradores de sequências curtas. Em suma temos os sequenciadores de terceira geração como o Oxford Nanopore e PacBio conhecidos por geração de sequências contínuas de até 1000 pares de base, portanto são conhecidos como sequenciadores de terceira geração.

\subsection{Aspectos históricos da metagenômica}

O termo metagenômica foi utilizado pela primeira vez pela pesquisadora norte americana Jo Emily Handelsman em 1998, em um estudo sobre amostras ambientais, para descobrir a diversidade microbiológica presente no solo. No mesmo estudo surgiu a ideia de que com um único sequenciamento pode ser obtido o conjunto de genomas de vários organismos presentes na mesma amostra (HANDELSMAN et al., 1988). No entanto, a metagenômica viral teve seu início apenas em 2002 com a descoberta 
de dois vírus não cultiváveis em comunidades virais marinhas, pertencentes a família Podoviridae e Siphoviridae (BREITBART et al., 2002).

Os resultados iniciais da metagenômica provocaram um impacto profundo na comunidade científica uma vez que ficou claro que este método pode ser aplicado para amostras clínicas. Em 2003 as amostras do meio ambiente deram espaço para a caracterização de amostras humanas, como por exemplo, fezes, biópsia cutânea, saliva dentre outros, assim caracterizando comunidades virais em humanos. Em 2003, Breitbart, M, e colaboradores apresentaram a primeira análise de metagenôma em fezes humanas, usando o método de sequenciamento shotgun parcial. Em 2006, Gill e colaboradores analisaram acerca de 78 milhões de pares de base, obtidos de uma única sequência de duas amostras fecais de dois adultos saudáveis. Outro aspecto muito importante da metagenômica viral, foi a descoberta de novos vírus humanos como por exemplo da família Polyomaviridae. Um desses vírus emergentes teve grande implicação clínica pois foi relacionado com o aparecimento do carcinoma maligno de Merkel, portanto, foi denominado poliomavírus Merkel (SHUDA et al., 2008, FENG et al, 2008). Mais recentemente, outros dois representantes adicionais do gênero poliomavírus humano (HPyV), denominados HPyV6 e HPyV7, foram encontrados na superfície da pele de indivíduos visivelmente saudáveis (SCHOWALTER et al., 2010). Em 2009, Willner, D, e colaboradores foram responsáveis pelo primeiro estudo metagenômico de comunidades virais nas vias aéreas de indivíduos doentes e saudáveis que detectaram uma gama de herpesvírus (HHV), incluindo o vírus Epstein-Barr (Herpesvírus humano-4, HHV-4), Herpesvírus humano do tipo 6B e 8P.

A metagenômica viral além de ser uma abordagem potente para identificação de vírus em amostras ambientais também se torna uma poderosa ferramenta na clínica. (ROSE et al., 2016). Com a utilização da metagenômica em amostras clínicas podemos 
descrever o viroma do paciente, desde vírus comensais á agentes infecciosos causadores de graves quadros clínicos. Com isso podemos verificar as interações patógenos/hospedeiro de uma forma ampla. Como no caso de pacientes que recebem bolsas de sangue, que por eventualidade podem estar contaminadas com algum agente nocivo à saúde do paciente.Este paciente que muitas vezes está imunologicamente debilitado, ou seja, uma infecção sem agravantes em um paciente assintomático pode gerar sérios riscos ao transfundido (SAUVAGE e ELOIT, 2016). Porém nesse contexto ainda é necessário múltiplas melhoras, onde podemos citar as plataformas de sequenciamento e principalmente a análise bioinformática dos dados gerados.

\subsection{Análises bioinformáticas}

\subsubsection{Histórico}

Com o advento das tecnologias de SNG se tornou cada vez mais evidente a necessidade de estruturas computacionais cada vez mais robustas e mão de obra qualificada para executar o processamento dos dados. Entretanto as atuais metodologias desenvolvidas e empregadas em bioinformática tem uma origem muito mais distante cerca de 50 anos atrás (GAUTHIER et al., 2019).

Ao contrário de que se pensa tudo isso não começou com o DNA mais sim com proteínas. Em meados dos anos 50 a área estrutural de proteínas se encontrava em pleno avanço com a utilização de técnicas como a cristalografia que permitia determinar a estrutura da proteína (JASKOLSKI, ZBIGNIEW e WLODAWER, 2014), além do mais a primeira sequência de proteína, a insulina, foi publicada (FREDERICK e THOMPSON, 1953). Dentre os avanços científicos que se destacavam na época podemos citar o método de degradação de Edman, que permitia o sequenciamento de proteínas, um aminoácido por vez a 
partir da parte N-terminal (EDMAN, 1949). Mais de 15 famílias de proteínas foram sequenciadas por este método (Figura 2), porém a degradação de Edman apresentava-se problemática quando se tratava de proteínas de maior comprimento. Esta técnica só conseguia sequenciar de 50 a 60 aminoácidos por vez e desta maneira grandes proteínas tinhamque ser quebradas em centenas de fragmentos (GAUTHIER et al., 2019). Este problema pôde ser resolvido com a primeira ferramenta de bioinformática, um montador de proteínas denominado COMPROTEIN. O programa foi desenvolvido por Margaret Dayhoff e Robert S. Ledley na plataforma IBM 7090. Este software foidesenvolvido em linguagem de programação FORTRAN e é considerado um dos primeiros modelos de montadores “ab initio” (DAYHOFF e LEDLEY, 1962).

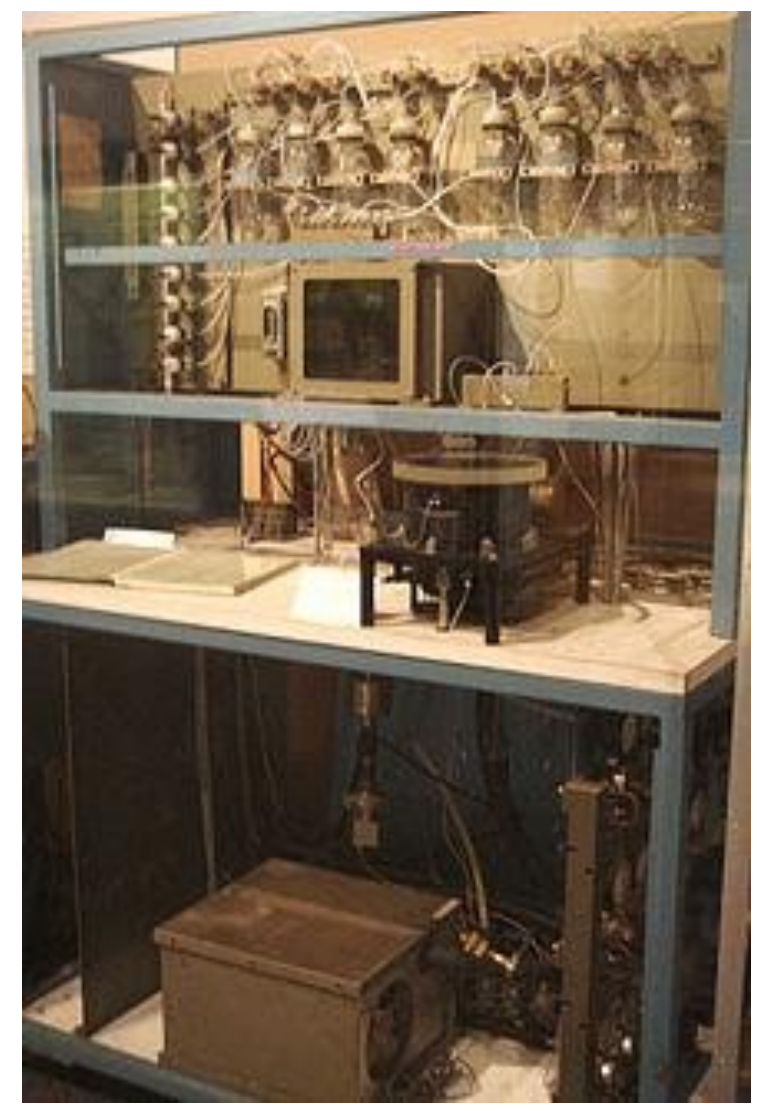

Figura 2. Sequenciador de peptídeos automatizado de Edman. Este foi um dos primeiros sequenciadores de peptídeos automatizado desenvolvido por William J. Dreyer. Adapatado de Gauthier, J et al., 2018. 
Com a evolução da obtenção dos dados gerados outras perguntas biológicas foram geradas como por exemplo a relação filogenética entre as sequencias de proteínas sequenciadas. Este trabalho muitas vezes em fragmentos pequenos e idênticos podia ser feito de forma manual assim atestando sua similaridade. Por outro lado, em sequências maiores e com disparidade esta análise se tornava sujeita a múltiplos erros. Em 1970 Needleman e Wunsch desenvolveram o primeiro algoritmo para alinhamento de proteínas (NEEDLEMAN e WUNSCH, 1970). Entretanto apenas em 1980 foi lançado o primeiro algoritmo de múltiplo alinhamento de sequências, uma das mais populares ferramentas de alinhamento o CLUSTAL foi desenvolvido apenas em 1988, todavia até os dias de hoje é amplamente utilizado (HIGGINS e SHARP, 1988).

Porém este cenário estava prestes a mudar, em 1958 Francis Crick postulou o dogma central da biologia em que descrevia que sequencias de RNA transcritas peloDNA determinavam a sequência de aminoácidos em uma proteína (CRICK, 1968). Assim começou a busca para o sequenciamento do DNA e um dos primeiros métodos implementados para sequenciamento de DNA foi o de Maxam-Gilbert (MAXAM e GILBERT, 1977). Por ser um método complexo e pelo uso de compostos altamente tóxicos (hidrazina, sulfatos, piperídina, hidróxido de sódio e potássio) e radioativos (isótopo de fósforo radioativo, $\mathrm{P}^{32}$ ) foi substituído pelo método aplicado por Frederick Sanger que é utilizado até hoje (GAUTHIER et al., 2019). Com as sequencias de DNA geradas foi constatado que a sua utilização tinha algumas vantagens sobre as proteínas em análises filogenéticas, por exemplo mutações no DNA que pediam ou não alterar os aminoácidos gerados. Desta maneira surgiram os primeiros programas especializados em análise do DNA 
como o GCG software (DEVEREUX e SMITHIES, 1984), um pacote desenvolvido para analisar DNA, RNA e proteínas e o DNASTAR que tinha como entrada de dados as sequencias geradas pelo sequenciamento de Sanger (GAUTHIER et al., 2019). Em 1995 o primeiro genoma completo de um organismo foi sequenciado, o da bactéria Haemophilus influenzae (FLEISCHMANN et al., 1995), porém, o marco inicial que nos levou a genômica como a conhecemos hoje foi o sequenciamento do genoma humano. O processo começou em 1991 (LANDER et al., 2001) e reuniu esforços colaborativos de várias equipes e anos de trabalho. Este sequenciamento foi feito por método Sanger (gerando fragmentos de no máximo $1000 \mathrm{pb}$ ) e resultou em surgimento de vários montadores de genoma e dentre eles podemos destacar o PHRAP (GORDON e GREEN, 1998), Celera assembler (MYERS et al., 2000), TIGR assembler (SUTTONet al., 1995), dentre outros.

Porém com o advento do SNG que começou com a tecnologia de sequenciamento trazida pelo sequenciador 454 (MARGULIES et al., 2005) da empresa Roche, tarefas como o sequenciamento do genoma humano cada vez se tornaram menos onerosas e podiam ser feitas por equipes menores. Com o tempo o custo e tempo do sequenciamento se tornaram cada vez menores. Hoje temos centenas de softwares desenvolvidos para lidar com os problemas específicos da genômica assim como diversas linguagens de programação que nos auxiliam a resolver problemas biológicos. Outro grande avanço é representado pelos bancos de dados biológicos que nos permitem ter acesso a um enorme acervo de dados já sequenciados. Dentre estes bancos podemos destacar o NCBI (www.ncbi.nlm.nih.gov), EMBL (www.embl.org), PDB (www.rcsb.org) dentre outros. 


\subsubsection{Pipelines de identificação viral}

Pipeline tem como definição uma sequência de passos a serem executadas para se alcançar o melhor resultado possível no final do processo (TATUSOVA et al., 2016). Em análises genômicas buscamos dessa mesma maneira uma sequência de passos para melhor extrair informações dos dados sequenciados.

A implementação de uma pipeline para análise metagenômica é composta por passos usuais como verificação de qualidade dos dados e limpeza, assim como partes especificas como classificação massiva das sequências geradas. Primeiramente as sequencias passam por um controle de qualidade e limpeza de sequências duplicadas e ambíguas. Em seguida é realizada uma segunda limpeza a fim de eliminar caudas poli-x (A, G, C, T), para posterior classificação taxonômica dos microrganismos presentes na amostra e montagem do genoma "ab initio".

\subsubsection{Controle de qualidade dos dados}

A primeira fase da análise para implementação de um pipeline eficiente para análise metagenômica é baseada no controle de qualidade das sequências provenientes do sequenciamento. O formato de entrada primariamente vindo para análise é o Fastq e, portanto, em primeiro lugar a sequencias passam pela ferramenta FastQC (ANDREWS,2010) versão 1.1.0. O FastQC visa fornecer um relatório de controle de qualidade que detecte problemas que se originam no sequenciador ou no material da biblioteca inicial (COCK et al., 2009). Desta forma o programa gera um valor Q para representar este parâmetro de qualidade. $\mathrm{O}$ valor de qualidade $\mathrm{Q}$ obtido representa um mapeamento inteiro da probabilidade de que a base identificada esteja incorreta (valor p). A pipeline Solexa(o software dos aparelhos Illumina) usa um mapeamento codificando as probabilidades $p /(1-p)$ : 
Qsolexa. prior para v. $1.3=-10 \log 10^{\frac{P}{1-}} P$

O FastQC visa fornecer uma maneira simples para verificações de controle de qualidade. Este programa fornece um conjunto modular de análises que pode ser utilizado para dar uma rápida impressão de dados e se existe algum problema que comprometer a análise total de dados (COCK et al., 2009; ANDREWS, 2010). Abaixo destacamos os principais parâmetros a serem analisados no controle de qualidade (Figura 3):

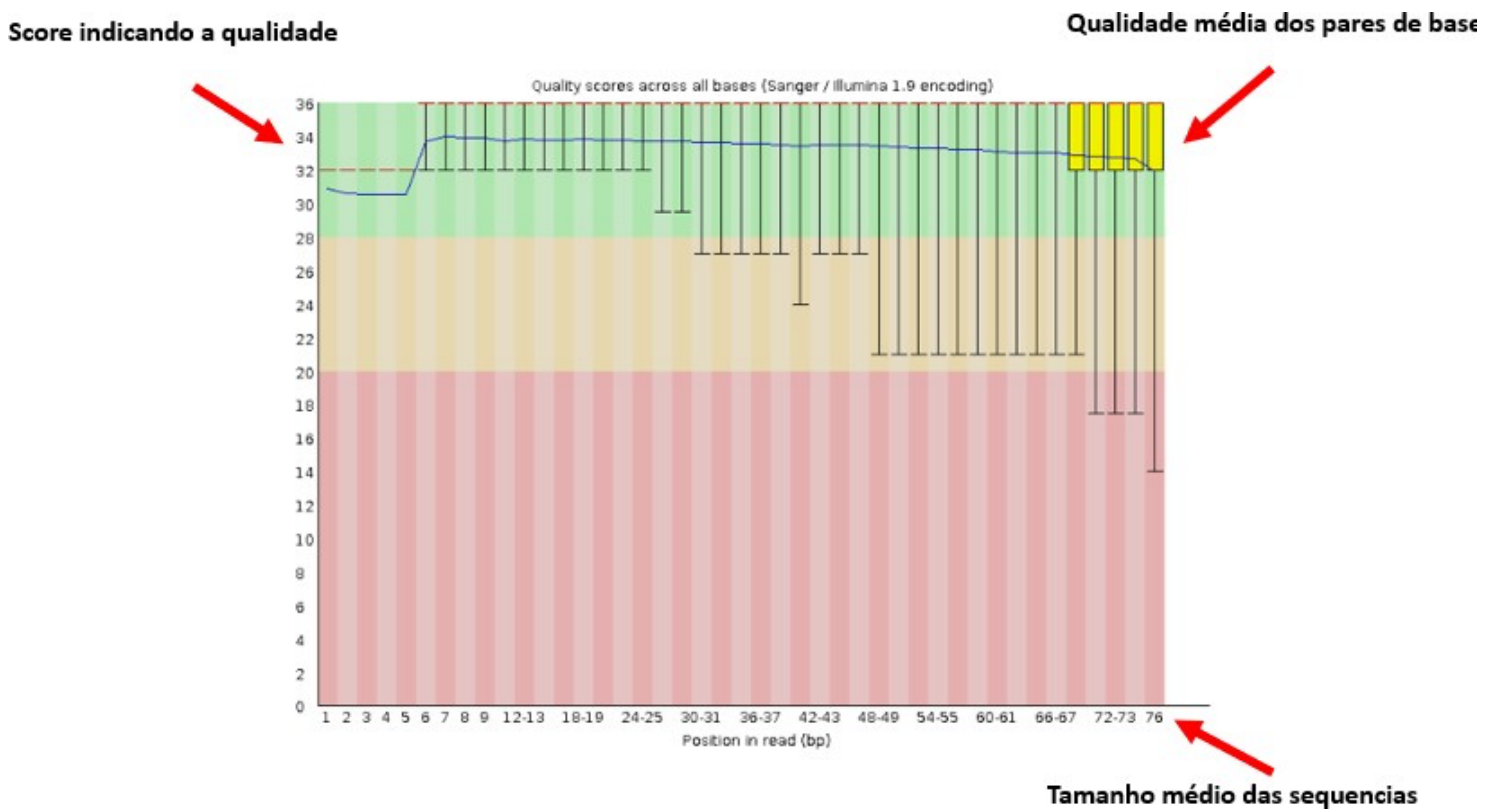

Figura 3. Gráfico de controle de qualidade gerado pelo software FastQC. No eixo Y podemos verificar a pontuação de qualidade dos dados, no eixo $\mathrm{X}$ se encontra o tamanhomédio das sequências analisadas. A linha azul corresponde a qualidade média por paresde base em determinado comprimento da sequência. 


\subsubsection{Limpeza das sequências geradas}

Para este passo utilizamos dois softwares diferentes e com finalidades unicas, para melhorar a qualidade dos dados para as fases subsequentes. Assim o processo é iniciado pelo Trimmomatic (BOLGER, 2014) versão 0.3.9, onde são retiradas sequencias com qualidade abaixo de 32 pontos. Depois essas sequências de alta qualidade passam pelo software AfterQC (CHEN et al., 2017) versão 0.9.6 que tem como função a retiradadas bases ambíguas (como bases marcadas com N, ou seja bases que o sequenciador nãoidentificou com $99,9 \%$ de certeza) e de caudas poli-x (repetições no final da sequência deA, C, G, T) que podem interferir no processo de classificação e montagem das sequencias.

\subsubsection{Classificação taxonômica}

Para este passo é utilizado o programa Kraken2 (WOOD e SALZBERG, 2014), que é uma ferramenta de classificação taxonômica cuja velocidade é superior comparada com o BLAST convencional. A maior velocidade é resultado ao uso da consulta de um banco de dados que contem $\boldsymbol{k}$-mers (todas as possíveis subsequências de uma leitura obtida através das sequências), em vez de alinhamento simples. A base operacional do Kraken contém um banco de dados que é composto de $k$-mers de todos os organismos. Este banco, construído usando uma biblioteca de genomas especificada pelo usuário, permite uma rápida pesquisa da classificação mais específica das relações filogenéticas associadas a um dado k-mer. Sequências que não possuem $k$-mers no banco de dados, não são classificadas pelo Kraken e posteriormente essas sequências devem ser analisadas pelo BLAST (ALTSCHUL et al., 1990). 


\subsubsection{Montagem dos genomas}

Esta etapa é executada pelo programa SPAdes (BANKEVICH et al., 2012) versão 3.13.0. O SPAdes assim como o Kraken2 usa uma abordagem de $k$-mers para construir sequencias maiores. Este método consiste em quebra das sequências em fragmentos menores específico e sua sobreposição. O programa SPAdes estima as 'distâncias' de matriz em vez de usar 'tamanhos de inserção'. Ao utilizar a abordagem deajuste de k-bimer, as distâncias são estimadas com exatidão. Um k-bimer é consistindo de k-mers ' $\alpha$ ' e ' $\beta$ ' juntamente com a distância estimada entre eles em um genoma $(\alpha \mid \beta, d)$ (BANKEVICH et al., 2012). Abaixo podemos ver um esquema geral do funcionamento dos k-mers tanto na montagem do genoma quanto no processo de classificação taxonômica (Figura 4).

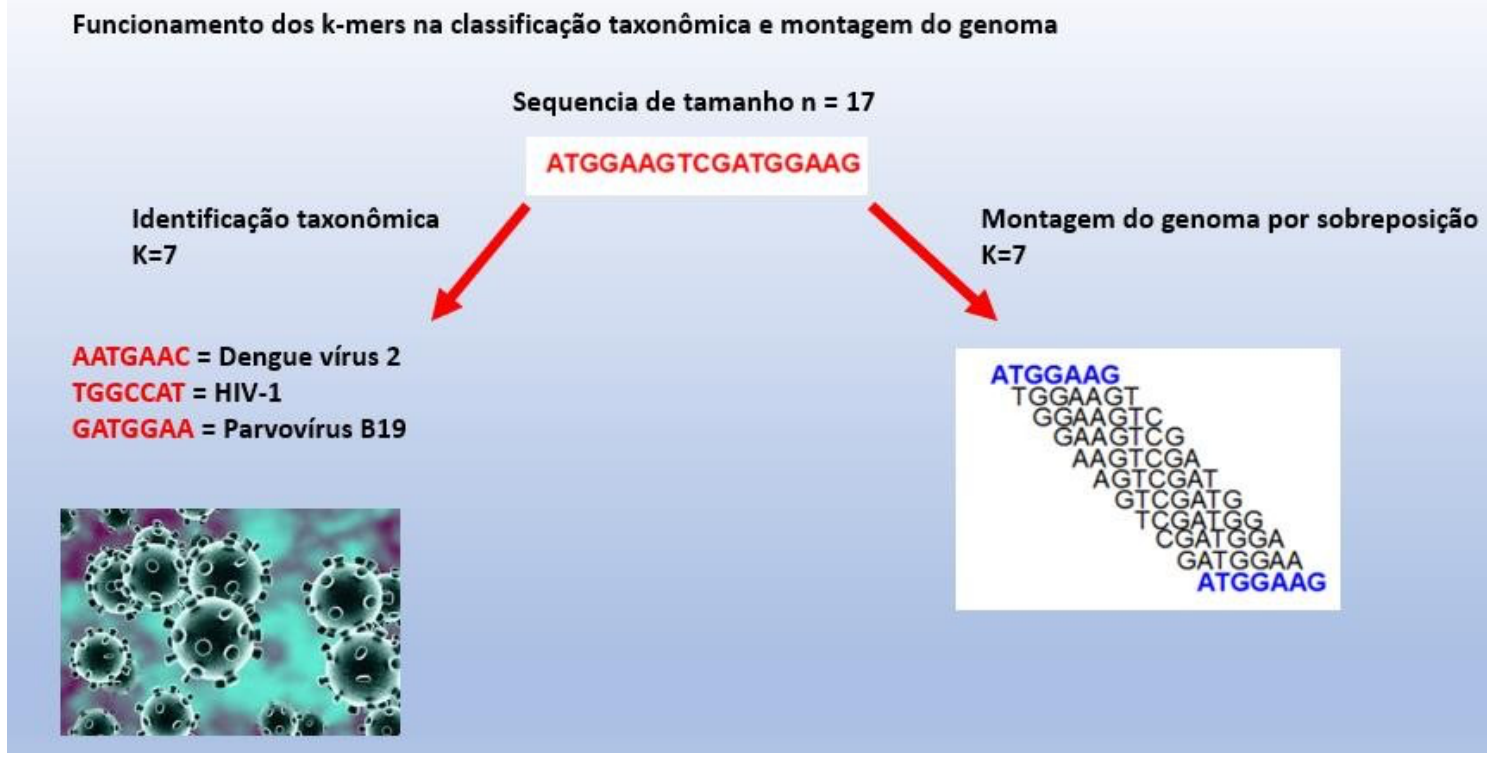

Figura 4. Utilização de k-mers na classificação taxonómica das sequências processados e na montagem do genoma por sobreposição dos fragmentos. Neste exemplo temos umasequência de 17 nucleótidos que para ser processada foi quebrada em fragmentos menores de 7 nucleótidos, ou seja, $\mathrm{k}=7$ (7-mers). 


\subsubsection{Diamond}

A última etapa da pipeline se baseia na classificação das sequências que o Kraken2 não conseguiu classificar com a utilização do software Diamond. O Diamond utiliza uma estratégia baseada na tradução das bases nucleotídicas para proteínas. Desta forma ele minimiza o esforço computacional e contrapõe essas proteínas contra um banco de dados específico. Isso gera uma agilidade imensa nos processos de classificação em comparação ao BLAST tradicional.

\subsection{Principais problemas encontrados nas análises bioinformáticas}

A análise bioinformática dos dados gerados por estas plataformas segue como um dos grandes desafios desta área. Dentre eles podemos citar a recuperação das sequênciasvirais geradas. Isso pode ocorrer por diferentes fatores, como a baixa carga das infecções virais, retrovírus endógenos, contaminações por sequencias virais ambientais presentes nos reagentes de SNG e extração que dificultam a sua identificação. Para isso podemos usar duas diferentes abordagens: (i) a montagem (assembly) com um genoma de referência, que se torna computacionalmente menos exaustiva. Porém esta técnica é aplicável para caracterização de genomas conhecidos. Para genomas de vírus emergentes que não são caracterizados o ideal é a utilização da montagem "ab initio", ou seja, sem um molde a ser seguido. O processo de montagem se torna essencial para se obter sequências maiores. Isso permite caracterizar diversas áreas do genoma estudado de uma maneira mais robusta, como genes mutados, regiões ligadas a virulência, dentre outras características (MEDVEDEV e BRUDNO, 2008; NIELSEN et al., 2014). Porém temosalguns erros gerados na montagem "ab initio", como sobreposições de sequências duplicadas e erros do sequenciamento. Isso pode gerar uma sequência consenso com múltiplos erros a serem corrigidos. Para 
evitarmos tais erros na montagem podemos seguir alguns procedimentos como a remoção de duplicatas, correção de pares de bases,e executar corretamente processos anteriores como a limpeza das sequências de baixa qualidade e eliminação de bases ambíguas. Todos esses procedimentos são extrema importância para a obtenção de sequências corretas e são denominadas como trimming (do inglês podar) (ALKAN, SAJJADIAN e EICHLER, 2011). Também podemos seguiroutra linha e classificar as nossas sequências antes de fazer a montagem (ii). Para isso existem classificadores taxonômicos potentes que levam menos tempo para executar este processo comparados com os classificadores tradicionais como o BLAST. Dentre eles podemos citar o Kraken2 (WOOD e SALZBERG, 2014), que é baseado em repetições de fragmentos curtos denominados k-mers, que muitas vezes por serem pequenos e compartilharem regiões em comum com outros vírus levam a uma classificação equivocada. Para evitar esses erros, uma confirmação das classificações geradas se demonstra eficiente. Desta forma seus resultados podem ser confirmados com BLASTn ou BLASTx subsequente para validação do método (MANDE, MOHAMMED e GHOSH, 2012). Isso nos mostra outro problema representado pelos bancos de dados públicos disponíveis que são usados como referências. Muitas vezes esses bancos de dados contêm informações faltantes ou errôneas que podem prejudicar a identificação de organismo estudado ou mesmo a própria identificação (GHISALBERTI, MASSEROLI e TETTAMANTI, 2010). Visando corrigir esse problema é indicado a utilização de bancos de dados específicos para determinados vírus como o VIPR (www.viprbrc.org), onde podemos encontrar dados virais constantemente atualizados. Desta maneira conseguimos realizar uma análise mais robusta e rigorosa em relação a outros bancos de dados. 


\subsection{Análise filogenética}

As análises filogenéticas podem ser divididas em duas partes i) filogenia e ii) filodinâmica. Desta maneira estruturamos duas diferentes pipelines a serem seguidas nessas metodologias que diferem em métodos estatísticos. Inicialmente as sequencias recuperadas da pipeline de metagenômica viral, passam por um alinhamento com outrassequencias de vírus da mesma espécie para iniciar a comparação evolutiva. Este dataset inicial é construído através de sequências já depositadas em bancos de dados como o NCBI (www.ncbi.nlm.nih.gov), EMBL (www.embl.org) e o VIPR (www.viprbrc.org). As sequências do dataset formado são alinhadas principalmente utilizando o software MAFFT (KATOH et al., 2002) versão 7.450. O MAFFT apresenta dois métodos heurísticos diferentes, o método de alinhamento progressivo (FFT - NS - 2) e o método de refinamento iterativo (FFT - NS - i), os dois métodos são baseados na construção de uma matriz de distância guiada por uma comparação global das sequências.

Há outros softwares de alinhamento, porém o MAFFT apresenta desempenho superior e tem um gasto computacional drasticamente reduzido em comparação com o CLUSTALW (LI, 2003) com precisão comparável, além de ser 100 vezes mais rápido que o T-COFFEE (NOTREDAME, DESMOND e HERINGA, 2000) quando o número de sequências de entrada excede 60 , sem sacrificar a precisão. Após o alinhamento as sequências são editadas manualmente e servem de entrada para construção da árvore filogenética, porém antes de iniciar a reconstrução filogenética é necessário avaliar se assubstituições nucleotídicas contidas nas sequências geram um sinal de divergência genética significante o suficiente para compará-las evolutivamente. 
De acordo com Hills \& Huelsenback (1992) as sequencias de DNA ou de outro tipo de dado molecular, quando comparadas entre os organismos podem conter sinal filogenético ou podem estar totalmente randomizadas na sua história filogenética. Para a avaliação do sinal filogenético existem vários algoritmos como por exemplo teste de permutação (Permutation probability test) usado pelo software PAUP, ou o teste G1 que é uma variação do teste PTP. No entanto atualmente para avaliação do sinal filogenético é utilizada o software TREE-PUZZLE (SCHMIDT et al., 2002) versão 5.3. O sinal filogenético pode ser avaliado através de gráficos. Dentre os parâmetros que podemos avaliar está o nível de saturação das sequências do dataset (figura 5A) que é dependentedo tamanho das sequências ou seja quanto menor a sua sequência, maior a saturação e desta forma menor a informação genética que pode ser retirada deste conjunto de dados. Outro parâmetro importante é o mapeamento de máxima verossimilhança que a partir daseleção de 4 sequencias aleatórias gera 3 possíveis árvores e a probabilidade destas árvores estarem corretas. Estes valores estão localizados nas extremidades do gráfico (figura 5B) e a soma dos 3 valores tem que ser superior a $60 \%$ para se ter um sinal confiável. O valor encontrado ao centro é relativo à percentagem de árvores não resolvidas e os valores laterais são relativos as árvores resolvidas. A probabilidade de resolução está diretamente ligada ao nível de saturação do dataset (Figura 5B). 
A

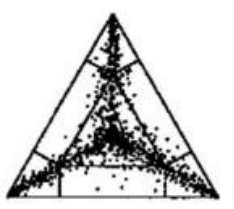

$50 \mathrm{pb}$

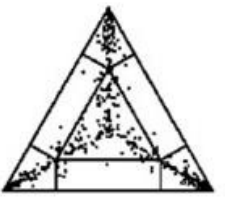

$100 \mathrm{pb}$

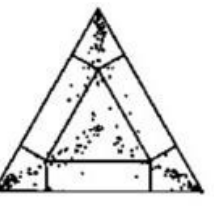

$200 \mathrm{pb}$

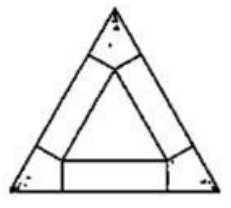

$500 \mathrm{pb}$
B
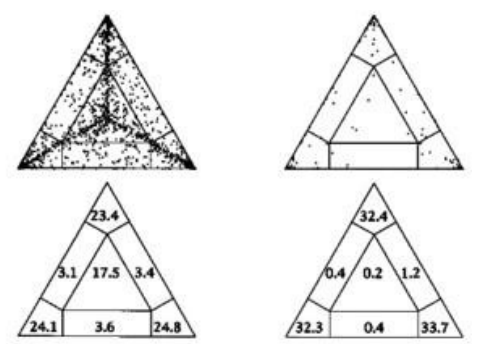

Figura 5. Avaliação do sinal filogenético pelo software TREE-PUZZLE. A) Nível de saturação. O nível de saturação está diretamente ligado ao tamanho das sequências inclusas no dataset, ou seja, quanto menor a sequência maior a saturação e menor será osinal filogenético encontrado. B) Mapeamento de máxima verossimilhança. A soma dos 3 valores nas extremidades do triangulo tem que ser superior a $60 \%$ para se ter um sinalconfiável. $\mathrm{O}$ valor encontrado ao centro é relativo à porcentagem de árvores não resolvidas e os valores laterais são relativos as árvores resolvidas. A probabilidade de resolução está diretamente ligada ao nível de saturação do dataset. Adaptado de Schmidt,

H.A et al., (2002).

Após a avaliação do sinal filogenético é realizada a reconstituição taxonômica utilizando o software IQ-TREE (NGUYEN et al., 2014) versão 1.6.8, que emprega uma abordagem de Máxima Verossimilhança (Maximum Likelihood). Outros programas de reconstituição taxonômica incluem o RAxML e o FastTree (LIU, LINDER e WARNOW, 2011) que utilizam a mesma metodologia. O método da Máxima Verossimilhança é dos mais utilizado em reconstruções filogenéticas dentro da abordagem estatística. Este método foi desenvolvido pelo Felsenstein (1981) que considera todos os sítios indistintamente. É um método considerado paramétrico, pois envolve parâmetros (vetormédia e matriz de covariância) e é supervisionado, pois estima estes parâmetros através de amostras de treinamento (QUEIROZ, RODRIGUES e GÓMEZ, 2004). Outra vantagem a ser citada do programa IQ-TREE é o fato dele escolher o melhor modelo desubstituição nucleotidica cabível aos dados obtidos aplicando o critério de inferência bayesiano (BIC). 
A outra abordagem é representada pelas análises filodinâmicas que englobam asanálises de relógio molecular (molecular clock) e filogeográfica. Inicialmente os dados são avaliados para a presença de sinal temporal. Este sinal é avaliado com a utilização do programa TempEst (RAMBAUT et al., 2016) versão 1.5.3. O sinal temporal funciona demaneira parecida como o filogenético, porém além de levar em conta as substituições nucleotídicas também analisa o tempo relacionado a essas mutações.

Para reconstrução das árvores temporais é utilizado o software BEAST (DRUMMOND, 2007) versão 1.10.4. O BEAST é um programa que utiliza inferência bayesiana usando o método de Monte Carlo acoplados a cadeias de Markov (Monte Carlo Markov Chain, MCMC). Desta forma ele pode inferir árvores temporais usando modelos de relógio molecular estritos ou relaxados (Figura 6). Além disso este algoritmo pode ser usado para testar hipóteses evolutivas sem condicionar a topologia de uma única árvore.Assim o programa usa a MCMC para inferir a média de espaço da árvore, para que cadaárvore seja ponderada proporcionalmente à sua probabilidade posterior (DRUMMOND,2007). Para a visualização das árvores filogenéticas são utilizados diferentes softwares incluindo o FigTree (RAMBAUT, 2012) versão 1.4. 


\section{Relógio Restrito VS Relaxado}

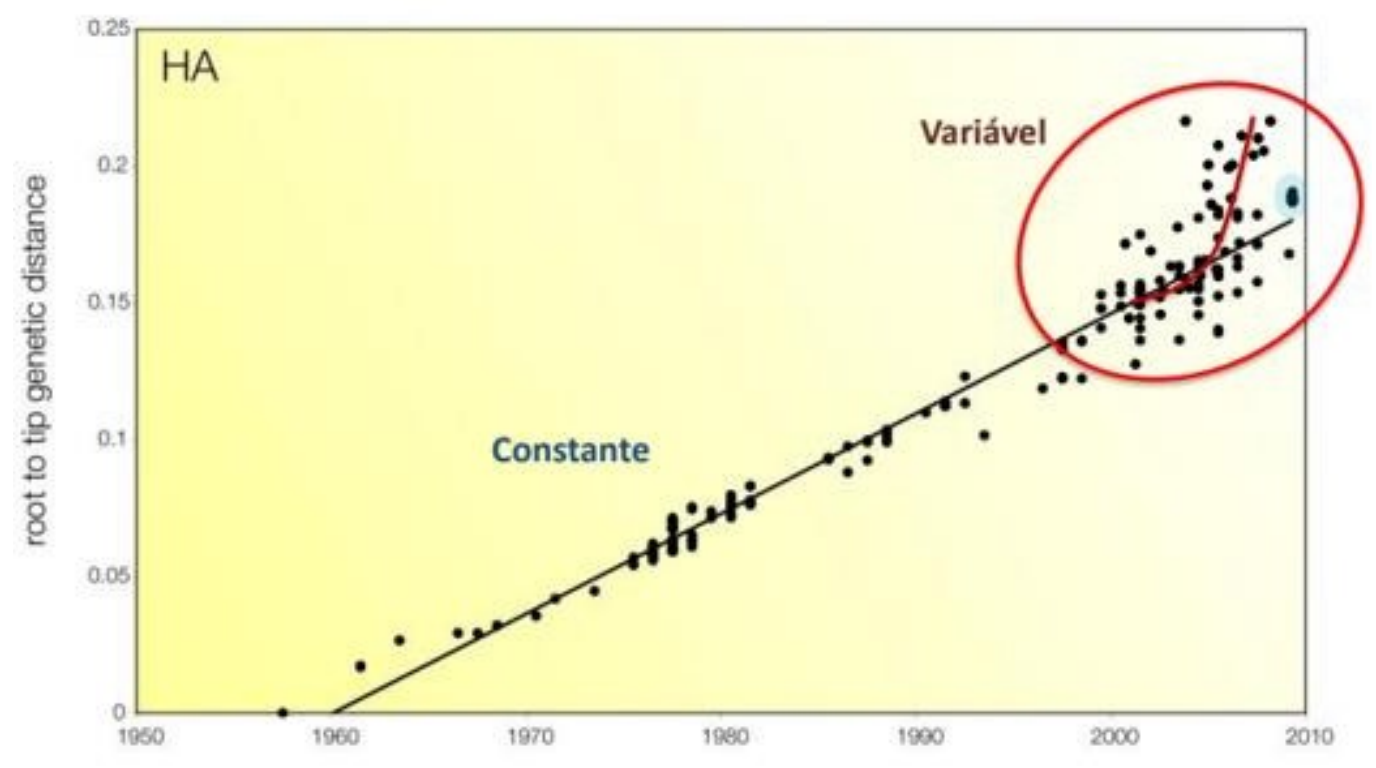

Figura 6. Modelos de relógio molecular estrito e relaxado. Além de padrões de modelagem populacional o BEAST leva em consideração a variação da taxa evolutiva em relação tempo/espaço, desta maneiro no caso dos vírus que sofrem uma alta taxa de mutação em curtos períodos o modelo de relógio molecular mais indicado seria o relaxado. Adaptado de Suchard, MA et al., 2018.

\subsection{Utilização da metagenômica na identificação de agentes patogênicos e seuimpacto na área de hemoterapia.}

O sangue doado e os seus derivados são utilizados diariamente em diversas práticas médicas desde a sua forma integral, como em frações especificas. Mesmo com o rígido controle de qualidade das bolsas de sangue, incluindo a triagem obrigatória de HIV, HBV, HCV, HTLV, sífilis e doença de Chagas (tripanossomíase americana), pode existir um grande número de agentes infecciosos não suspeitos que podem afetar a segurança transfusional (APPLEMAN et al., 1993, STRAMER et al., 2009, PHAN et al., 2015). É impossível a implementação na rotina diagnóstica testes para todas as doenças infecciosas que possam afetar a segurança transfusional, porém a metagenômica viral pode revelar agentes virais emergentes que podem impactar a hemoterapia e melhorar as diretrizes relacionadas a segurança do sangue transfundido. Neste aspecto, 
pesquisas metagenômicas em pessoas assintomáticas identificaram mais de 94 espécies virais, das quais destacavam-se os representantes das famílias dos herpesvírus e anellovírus, bem como papilomavírus (incluindo o oncogênico HPV16) e um novo astrovírus humano dotipo MLB2 (ŠROLLER et al., 2016; MOUSTAFA et al., 2017; WALDVOGEL-ABRAMOWSKI et al., 2019). Por outro lado, estudos metagenômicos em bolsas de sangue na China identificaram sequencias relacionadas à Coxiella burnetii, (XU et al., 2018) que é uma bacteria zoonótica causando doença grave em humanos. Esses dados demonstram a grande quantidade de patógenos que pode ser transmitida via transfusão de sangue e possivelmente impactar receptores de hemoderivados.

Neste contexto para aumento da segurança transfusional além dos exames de cunho obrigatório, há entrevista de pré-seleção onde alguns hábitos da vida do doador são investigados a fim de se evitar futuros problemas na aplicação do sangue obtido. Porém nessa entrevista, o doador qualificado pode ser assintomático, inclusive na fase de viremia e os sintomas de doenças infecciosas podem aparecer algum tempo após a doação. Neste caso o paciente é avisado a ligar para a unidade de coleta e informar que apresentou algum tipo de sintoma como febre, exantema, conjuntivite, dores retro orbitais, artralgia, mialgia, diarreia, vômitos, enjoo, dentre outros que podem indicar algum tipo de infecção (WILKINSON et al., 2011; VUK et al., 2019). Estes casos são classificados como Doença Pós-Doação (DPD). No entanto, devido ao grande número de patógenos que podem causar esses sintomas não é viável aplicar teste direto para todos os agentes patogénicos possíveis que podem ameaçar a segurança transfusional. Portanto, a maneira mais adequada de investigar se o DPD fornecido está relacionado a uma infecção viral é aplicar o SNG a essas doações. A confirmação da causa do DPD pode revelar sua importância para a segurança da transfusão para 
impedir a transmissão de doenças virais. Ainda, a informação desses agentes pode ser crítica para elaboração de protocolos e políticas públicas de prevenção de transmissão de doenças infecciosas cuja triagem não é obrigatória nos centros de hemoterapia, principalmente dengue (SABINO et al., 2012). Além disso, o Brasil é um país tropical onde circulam diversos agentes virais que podem demonstrar transmissão transfusional o que torna imprescindível a aplicaçãodos métodos metagenômicos e SNG para sua identificação em doadores de sangue reportando DPD.

Desta forma o foco deste estudo é a análise bioinformática de amostras provenientes de bolsas de sangue com DPD e amostras obtidas de doadores de sangue infectados pelos principais agentes infecciosos triados nos bancos de sangue (HIV, HBV, HCV, HTLV, sífilis, doença de Chagas). Assim, demonstrando a importância da investigação de bolsas de sangue e dos agentes virais circulantes na população de doadores o que poderá auxiliar em medidas públicas de saúde e controle epidemiológico. 


\section{JUSTIFICATIVA}

No Brasil, não existem estudos que avaliam o viroma e o impacto de vírus emergentes, re-emergentes e não suspeitos na área de hemoterapia. Desta maneira uma investigação aprofundada nesta área é de suma importância para entendermos e traçarmos um panorama do perfil transfusional no país. Os riscos transfusionais com agentes virais exóticos já existem comprovadamente, como dengue vírus (MOHAMMED et al., 2008; LINNEN et al., 2008; SABINO et al., 2012), vírus da encefalite japonesa (CHENG et al.,2018), West Nile (PEALER et al., 2003), dentre outros que podem causar sintomatologia grave em pacientes transfundidos. Neste contexto, um modelo que se encaixa no estudode possíveis agentes virais de etiologia desconhecida que podem apresentar transmissão transfusional são as amostras de DPD. Ao paciente ligar ao centro de coleta e informar que apresentou algum sintoma após doação (principalmente febre) essas bolsas são, na maioria dos casos, descartadas sem sequer saber se há um possível agente viral patogênico presente. Desta maneira, saber quais vírus podem ser agentes causadores de DPD pode ajudar a entender os vírus passíveis de futuros testes de triagem de rotina de doadores desangue, novas infecções circulantes na população de doadores bem como a implementação de políticas públicas que podem amenizar ou prevenir sua transmissão transfusional.

Desta forma, a metagenômica é uma solução de alto desempenho para identificação desses agentes virais desconhecidos. Porém com a geração de dados por SNG vem outro desafio, processar grandes montantes de dados de forma eficaz e passível do mínimo possível de erros. Assim o desenvolvimento de uma pipeline focada em metagenômica viral se torna essencial para obter resultados de alta confiabilidade, assimcomo o gerenciamento dos recursos computacionais disponíveis. É de suma importânciaa escolha dos softwares adequados para cada etapa, sendo que a maioria 
dos softwares disponíveis são para organismos modelo (Homo sapiens, Mus musculus) o que dificultaa extração dos dados provenientes de vírus. Portanto, o objetivo desse estudo é avaliação da presença de vírus emergentes, re-emergentes ou não suspeitos em dois grupos de amostras, i.e., bolsas de sangue com DPD (febre, exantema, conjuntivite, dores retro orbitais, artralgia, mialgia, diarreia, vômitos, enjôo) que foram indeferidas para transfusão bem como doações de sangue obtidas de doadores de alto risco da região norte e sul do país. 


\section{HIPÓTESE}

A hipótese principal deste trabalho é que mesmo com os exames mandatários como HIV-1/2, HBV, HCV e HTLV-1 e 2, ainda há diversas ameaças de cunho viral que podem acometer diretamente a saúde transfussional e não são identificadas pelos métodos atuais empregados pelas instituições de saúde no Brasil. 


\section{OBJETIVO GERAL}

O objetivo principal deste estudo é aplicar métodos bioinformáticos para avaliar a presença de vírus emergentes, re-emergentes e não suspeitos em bolsas de sangue com informação de DPD bem como em bolsas sangue obtidos de doadores com comportamento de risco em diferentes localizações do país. 


\section{OBJETIVOS ESPECÍFICOS}

1. Desenvolvimento e implementação de uma pipeline específica para análise de dados de SNG e metagenômica viral;

2. Aplicação de pipeline bioinformática para análise do viroma de amostras DPD e bolsas de sangue obtidas de doadores infectados pelos principais agentes infecciosos testados nos bancos de sangue i.e HIV-1/2, HTLV-1/2, HCV, HBV, doença de Chagas e sífilis;

3. Análise filogenética, filodinâmica e relógio molecular dos vírus identificados;

4. Discussão sobre o possível impacto dos vírus identificados na área de transfusão desangue e aplicações da metagenômica na hemoterapia. 


\section{MATERIAIS E MÉTODOS}

\subsection{Amostras clínicas}

As amostras clínicas deste estudo foram divididas em dois grupos i) amostras de doadores de sangue relatando DPD, ii) amostras de doadores de alto risco, infectados com HIV, HBV, HCV, sífilis e/ou doença de Chagas. As amostras de DPD foram obtidas noHemocentro de Ribeirão Preto - São Paulo, nos anos epidemiológicos de 2016, onde obtivemos amostras provenientes de um surto apresentando co-circulação dos vírus das febres Dengue e Zika e amostras de 2019/2020 com relato de DPD. Além do mais, coletamos amostras com DPD do ano epidemiológico de 2019 foram coletadas no Hospital Israelita Albert Einstein, São Paulo - São Paulo. O segundo grupo de amostras clínicas foi representado de doações de sangue obtidas de doadores de sangue infectados pelas principais agentes triados nos bancos de sangue HIV-1/2, HCV, HBV, HTLV-1/2, sífilis e doença de Chagas de duas regiões do país i.e. Norte (Centro de Hematologia e Hemoterapia de Macapá - Amapá) e Sul (Serviço de Hemoterapia de Santa Maria, Santa Maria - Rio Grande do Sul).

As amostras foram agrupadas em pools e sequenciadas, para melhor entendimento da composição dos pools e dos grupos formados dividimos em tabelas cada um dos diferentes experimentos acima citados. A tabela 1 apresentas as amostras do ano epidemiológico de 2019/2020, onde sequenciamos 10 pools com 76 amostras com DPD. Os principais sintomas relatados pelos doadores foram febre, exantema, conjuntivite, dores retro orbitais, artralgia, mialgia, diarreia, vômitos, enjôo. Todas as amostras com DPD foram obtidas do Hemocentro de Ribeirão Preto. 
Tabela 1. Amostras clínicas de doença pós-doação obtidas de doadores relatando DPD do Hemocentro de Ribeirão Preto/São Paulo, do ano epidemiológico de 2019.

\begin{tabular}{ll}
\hline $\begin{array}{l}\text { Doença Pós Doação 2019/2020 Ribeirão } \\
\text { Preto/SP }\end{array}$ & Amostras \\
\hline Pool 10-2019 & 11 \\
Pool 11-2019 & 5 \\
Pool 12-2019 & 9 \\
Pool 21-2019 & 6 \\
Pool 22-2019 & 8 \\
Pool 05-2020 & 6 \\
Pool 06-2020 & 5 \\
Pool 20-2020 & 9 \\
Pool 21-2020 & 9 \\
Pool 22-2020 & 8 \\
\hline Total & $\mathbf{7 6}$
\end{tabular}

Por fim um terceiro grupo (Tabela 2) de amostras, dividido em 4 pools, totalizando 46 amostras com DPD foi estabelecido incluído amostras de doadores de sangue com sintomas como diarreia, coriza, cefaleia, febre dentre outros durante um surto de Dengue e Zika na região de Ribeirão Preto, que ocorreu em 2016. Todas as amostras triadas eram negativas para RNA de DENV, ZIKV e Chikungunya, e foram previamente testadas para estes agentes virais através de PCR em tempo real. A necessidade de investigar essas amostras se deu pelo fato de encontrar possíveis coinfecções em surtos de flavivírus assim como outros agentes etiológicos que podem estar circulando a presença de sintomatologia característica de infecção arboviral porém as amostras foram negativas para as reações moleculares supracitadas.

Tabela 2. Amostras clínicas de doença pós-doação pertencentes a cidade de Ribeirão Preto/São Paulo, do ano epidemiológico de 2016.

\begin{tabular}{ll}
\hline Doença Pós Doação 2016 Ribeirão Preto/SP & Amostras \\
\hline Pool 07 & 12 \\
Pool 08 & 12 \\
Pool 09 & 12 \\
Pool 10 & 10 \\
\hline Total & $\mathbf{4 6}$ \\
\hline
\end{tabular}


Por fim 28 amostras com DPD divididas em 04 pools (Tabela 3) provenientes do Hospital Israelita Albert Einstein de São Paulo-capital foram coletadas. Dentre os sintomas relatados entre as amostras podemos citar febre, diarreia, cefaleia, coriza, tosse, vomito, dores de garganta e dores no corpo. Assim como as amostras de Ribeirão Preto, elas também são provenientes de DPD, e estas amostras foram triadas a fim de comparar se as diferentes localizações geográficas predispõem diversidade dos possíveis agentes virais que podem ameaçar a segurança transfusional dentro do estado de São Paulo.

Tabela 3. Amostras clínicas de doença pós-doação pertencentes a cidade de São Paulo/São Paulo, do ano epidemiológico de 2019.

\begin{tabular}{ll}
\hline Doença Pós Doação 2020 São Paulo/SP & Amostras \\
\hline Pool 01 & 7 \\
Pool 02 & 7 \\
Pool 03 & 7 \\
Pool 04 & 7 \\
\hline Total & $\mathbf{2 8}$
\end{tabular}

O segundo grupo de amostras clínicas provenientes de doadores de alto risco infectados com HIV, HBV, HCV, sífilis e doença de Chagas foi dividido em dois diferentes estudos: (i) amostras provenientes de doadores de alto risco de Macapá Amapá e (ii) amostras de doações provenientes de doadores de alto risco infectados comas infecções comuns triadas nos bancos de sangue de Santa Maria - Rio Grande do Sul.As amostras de Macapá (Tabela 4) geraram 12 pools com um total de 69 amostras a serem sequenciadas. Todas as amostras foram coletadas no ano epidemiológico de 2019/2020. 
Tabela 4. Amostras clínicas de doadores de alto risco pertencentes a cidade de Macapá/Amapá, do ano epidemiológico de 2019/2020.

\begin{tabular}{ll}
\hline Doadores alto risco Macapá/AP & Amostras \\
\hline Pool 23 & 5 \\
Pool 24 & 5 \\
Pool 25 & 5 \\
Pool 26 & 5 \\
Pool 36 & 6 \\
Pool 37 & 5 \\
Pool 38 & 5 \\
Pool 15 & 6 \\
Pool 16 & 6 \\
Pool 17 & 6 \\
Pool 18* & 2 \\
Pool 19* & 2 \\
\hline Total & 58 \\
*Pools com amostras de Macapá e & \\
Santa Maria (pool 18 contém 2 & \\
amostras de Macapá-AP e 6 de & \\
Santa Maria-RS e pool 19 contém & \\
2 de Macapá-AP e 5 de Santa \\
Maria-RS)
\end{tabular}

O segundo subgrupo das amostras de doadores de alto risco foi coletado no Serviço de Hemoterapia de Santa Maria, Rio Grande do Sul. As amostras foram divididas em 11 pools com um total de 72 pacientes (Tabela 5). O ano epidemiológico de coleta foientre 2019/2020. 
Tabela 5. Amostras clínicas de doadores de alto risco pertencentes a cidade de Santa Maria/Rio Grande do Sul, do ano epidemiológico de 2019/2020.

\begin{tabular}{ll}
\hline Doadores alto risco Santa Maria/RS & Amostras \\
\hline Pool 09 & 14 \\
Pool 28 & 6 \\
Pool 29 & 6 \\
Pool 30 & 6 \\
Pool 31 & 6 \\
Pool 32 & 6 \\
Pool 33 & 5 \\
Pool 34 & 6 \\
Pool 35 & 6 \\
Pool 18* & 6 \\
Pool 19* & 5 \\
\hline Total & $\mathbf{7 2}$
\end{tabular}

* Pools com amostras de Macapá e Santa Maria (pool 18 contém 2 amostras de Macapá-AP e 6 de Santa Maria-RS e pool 19 contém 2 de Macapá-AP e 5 de Santa Maria-RS)

\subsection{Geração dos dados por SNG.}

Os dados para as análises foram gerados por SNG, utilizando equipamento Illumina, modelo NextSeq 550 e NovaSeq 6000 gerando uma alta taxa de dados a serem analisados. A preparaçõ das bibliotecas e SNG foi realizada utilizando protocolo padrão da Illumina (www.illumina.com). As sequências brutas obtidas após o sequenciamento foram disponibilizadas no formato fastq para análise.

\subsection{Estrutura computacional}

Para implementação das análises bioinformáticas contamos como uma estrutura computacional robusta, o Equipamento MultiUsuário (EMU), localizado no laboratório de Genética Molecular e Bioinformática (LGMB), sendo um sistema de lotes portáteis (Portable batch System- PBS), que nos permite o escalonamento dos processos e ela submetidos, distribuindo os processos entre diversos recursos computacionais existentes. 
A EMU conta com 11 computadores, todos com o sistema operacional Linux, utilizandoa distribuição CentOS Linux versão 7.6.1810 em todos os nós do cluster, onde 10 dos 11 computadores possuem processadores AMD Opteron 6174, com um total de 20 cores e 64GB de memória RAM em cada nó, o único nó que conta com hardware diferente apresenta processadores Intel Xeon E7540, com um total de 20 cores e 120GB de memória RAM totalizando 220 cores e 760 GB de RAM. Para o armazenamento a EMUconta com três storages (unidades armazenadoras) sendo dois deles de $20 \mathrm{~TB}$ e um de $32 \mathrm{~TB}$, totalizando $72 \mathrm{~T}$ B de armazenamento.

\subsection{Pipeline utilizada inicialmente (introdução pela equipe do Instituto Pasteur)}

A pipeline inicialmente utilizada contava com os seguintes passos de processamento dos dados brutos provenientes por SNG (Illumina): i) controle de qualidade das sequências geradas, ii) limpeza de sequencias com baixa qualidade, iii) classificação taxonômica das sequencias, iv) Montagem "de novo" das sequencias e por final v) classificação porsimilaridade de nucleotídeos. Os dados para as análises foram gerados por SNG, utilizando equipamento Illumina, modelo NextSeq 550 e NovaSeq 6000 gerando uma alta taxa de dados aserem analisados. Depois do sequenciamento o primeiro passo a ser realizado é a demultiplexação (demultiplexing). Esse passo foi executado com o software bcl2fastq (https://support.illumina.com/sequencing/sequencing_software/bcl2-fastqconversionsoftware.html) versão 2.20 , onde os arquivos são dispostos compactados emsuas respectivas pastas para futura análise. Após essa etapa foi feito controle de qualidadeinicial pelo software FastQC (ANDREWS, 2010) versão 1.1.0. Para a limpeza dassequências é utilizado o software PrinSeq (SCHMIEDER e EDWARDS, 2011a) versão0.20.4, onde foi estabelecido um limite de 26 (relativamente baixo) pontos paraeliminação de sequências. Ainda na etapa de 
limpeza utilizamos o software DeconSeq(SCHMIEDER e EDWARDS, 2011b) versão 0.4.3 para retirada do DNA do hospedeiro utilizando como referência o genoma humano GRCh37. Para o passo de classificação taxonômica foi utilizado o software Kraken2 (WOOD e SALZBERG, 2014) versão 2.0.8, que é uma ferramenta de classificação taxonômica com alta velocidade que é resultado do uso de um banco de dados que contem k-mers (pequenas sequências de comprimentok), em vez de alinhamento global das sequências. Posteriormente executamos a etapa de montagem “de novo" das sequências classificadas como virais. Nesta etapa utilizamos software SPAdes (BANKEVICH et al., 2012) versão. A última etapa da pipeline consiste na utilização do BLAST (ALTSCHUL et al., 1990) para anotação final dos genomas encontrados e que não foram classificados pelo Kraken2. Para mais detalhes verificar Figura7.

\section{Pipeline Antiga}

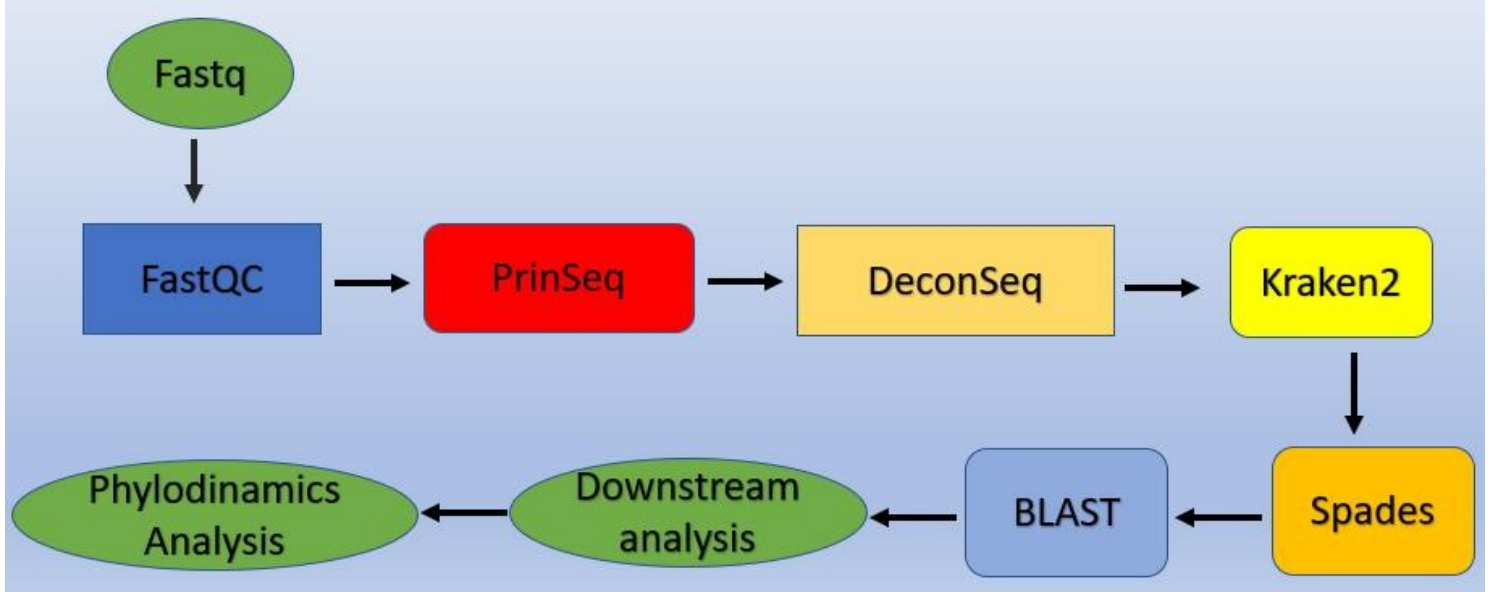

Figura 7. Pipeline utilizada inicialmente para o processamento dos dados de metagenômica. Os dados gerados inicialmente passam por um controle de qualidade, limpeza das sequências de baixa qualidade e descontaminação de DNA do hospedeiro. Posteriormente essas sequências são classificadas e montadas em sequências maiores (contigs ou genoma completo). Por fim passam para as análises filodinâmicas para entender o comportamento epidemiológico dos vírus encontrados. 


\subsection{Pipeline restruturada}

Por meio de uma restruturação em alguns passos a fim de otimizar o processo, modificamos algumas etapas da pipeline anteriormente utilizada. Os dados brutos do sequenciamento foram submetidos ao controle de qualidade utilizando o software FastQC (Andrews, S., 2010) versão 0.11.8. Após avaliar a qualidade das sequências foi realizada uma seleção destas com a melhor qualidade. Realizamos o corte de duas maneiras distintas (i) pelo uso do Trimmomatic (BOLGER, 2014) versão 0.3.9 para remover sequências de baixa qualidade, duplicatas e bases ambíguas e (ii) uso do Cutadapt (MARTIN, 2011) versão 2.4 para remoção de adaptadores Illumina. Para a análise subsequente, usamos apenas sequências com uma qualidade acima de 30 pontos. Além disso, realizamos uma segunda etapa de corte de sequências inadequadas usando o software AfterQC (CHEN et al., 2017) versão 0.9.7 para remover caudas de poli-X e bases ambíguas. Para inferir a classificação taxonómica das sequências, foi utilizado o programa Kraken 2 (WOOD e SALZBERG, 2014). A montagem "de novo" foi realizada usando o SPAdes (BANKEVICH et al., 2012) versão 3.13.0. Finalmente, a fim de identificar a similaridade de nucleotídeos e aminoácidos, realizamos um BLASTn e BLASTx com o uso do Diamond (BUCHFINK, 2015). O Diamond utiliza uma estratégia baseada na tradução das bases nucleotidicas para proteínas. Desta forma ele minimiza o esforço computacional e contrapõe essas proteínas contra um banco de dados específico. No caso utilizamos o banco completo de proteínas disponível no NCBI (https://www.ncbi.nlm.nih.gov/). Por fim utilizamos uma opção de virtualização de máquina com o Docker (MERKEL, 2014). Desta forma mantendo a estabilidade do script e dos programas bases utilizados. Para mais detalhes verificar Figura 8. 


\section{Pipeline Nova}

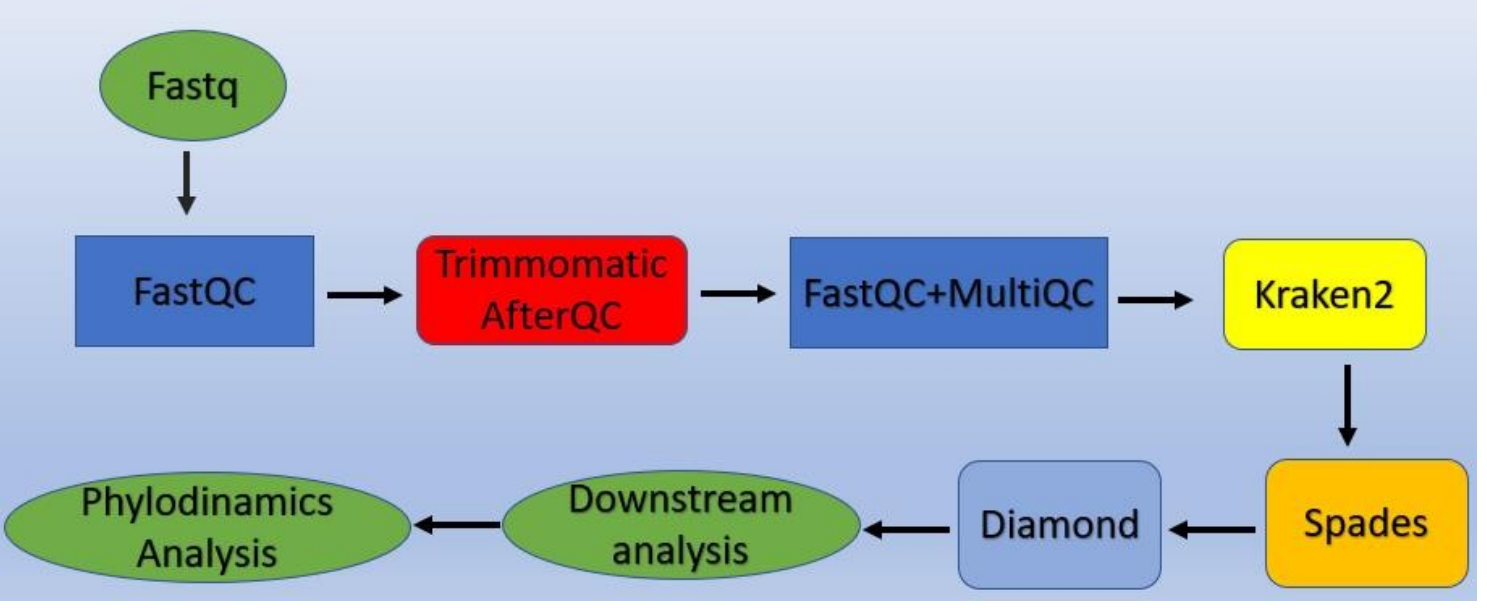

Figura 8. Pipeline nova utilizada para o processamento dos dados de metagenômica. Osdados gerados inicialmente passam por um controle de qualidade, limpeza em duas etapas das sequências de baixa qualidade e um controle de qualidade final. Posteriormente essas sequências são classificadas e montadas em sequências maiores (contigs ou genoma completo). Por fim passam para as análises filodinâmicas para entender o comportamento epidemiológico dos vírus encontrados.

\subsection{Análise filogenética, filogeográfica e relógio molecular}

Para condução das análises filogenética utilizamos sequencias de referências oriundas de bancos de dados públicos como o VIPR (https://www.viprbrc.org/) e o NCBI (https://www.ncbi.nlm.nih.gov/). Para realizarmos o múltiplo alinhamento dessas sequências, utilizamos o software MAFFT (KATOH et al., 2002) versão 7.450. Para verificarmos o sinal filogenético utilizamos o software TREE-PUZZLE (SCHMIDT et al., 2002) versão 5.3. Em outra abordagem verificamos o sinal temporal deste conjunto de sequências também, para isso utilizamos o software TempEst (RAMBAUT et al., 2016) versão 1.5.3. Em seguida para construção da arvore filogenética utilizamos diferentes métodos. Para arvores menos complexas, que tendem a inferir apenas a distância genética dos organismos, utilizamos o IQ-TREE (NGUYEN et al., 2014) versão

1.6.8 que utiliza uma abordagem baseada em Máxima Verossimilhança (Maximum Likelihood). Porém em questões mais complexas como filogeográfia, fizemos as 
análises utilizando o BEAST (DRUMMOND, 2007) versão 1.10.4, um software baseado em inferência Bayesiana, apresentando um algoritmo mais complexo. Por fim, para verificarmos a arvore gerado e para processo de edição utilizamos o FigTree (RAMBAUT, 2012) versão 1.4. 


\section{RESULTADOS}

\subsection{Análise bioinformática}

Inicialmente um treinamento foi recebido pelo Dr. Mathias Vandenbogaert, pesquisador da secção de bioinformática do Instituto Pasteur, Paris, França. Desta forma ocorreu a implementação do primeiro modelo de análises voltado a metagenômica viral. Porém ao ser verificado a funcionalidade da pipeline em algumas amostras se verificou uma alta taxa de falsa positividade assim como um processo de limpeza muitas vezes ineficiente deixando passar sequencias com altos níveis de repetição e bases ambíguas. Ao mesmo tempo o processo de remoção do DNA poderia afetar retrovírus endógenos ou vírus com composição génica parecida ao genoma humano. Desta forma poder-se-iam perder informações valiosas para o processo. As sequências ainda tinham uma baixa elevação de qualidade de 24 para 26 pontos no máximo. Mesmo com a paralezição de alguns processos, eles ainda eram computacionalmente exaustivos onde o processo de limpeza demorava cerca de 12 horas para ser executado. Somente o BLAST com o bancode dados completo que podia levar até 3 dias de trabalho paralelizado utilizando vários nós do cluster e apenas com o banco viral cerca de 12 horas.

A fim de corrigir essas possíveis falhas fizemos um modelo com algumas mudanças, sendo totalmente automatizado em linguagem computacional BASH script. A primeira etapa de controle de qualidade foi mantida com a utilização do software FastQC, porém na fase de limpeza os dois softwares da primeira pipeline (PrinSeq e DeconSeq) foram substituídos. Assim, o PrinSeq foi substituído pelo Trimmomatic versão 0.39 , o padrão de qualidade foi elevado para 32 para não perder possíveis sequências virais e em conjunto com este passo utilizamos o Cutadapt versão 2.4 para retirada dos adaptadores indesejáveis. Um passo a mais que não era feito na versão 
antiga, foi adicionado. Trata-se do software AfterQC versão 0.9.6 que substituiu o DeconSeq e tem como função a retirada das bases ambíguas e de caudas poli-X. Com este novo processo otimizamos o tempo de 12 horas para 6 horas para a análise de amostras de 55GB.

Como consequência conseguimos sequencias mais limpas e com menor taxa de repetição ou bases ambíguas assim como a retirada das caudas poli-X. Estes procedimentos ajudam na montagem "ab initio" melhorando os futuros resultados de nossa pipeline. A qualidade final depois da limpeza se encontra na faixa de 30 a 32 que ésignificativamente superior comparada com a qualidade da pipeline inicial.

A fase de classificação taxonómica com o Kraken2 foi mantida por ser considerado um bom método apesar de algumas falhas que são compensadas diante da agilidade do processo, porém apresenta um menor número de classificação falso positiva. O processo de montagem prosseguiu com o uso do software SPAdes. No entanto, agora é executada uma correção de bases antes do processo de montagem oferecendo uma maior confiabilidade do processo e o deixa sujeito a menos erros. Por enquanto, essa fase não é totalmente automatizada mas a intenção é integrá-la de forma total em script em BASH.

O BLASTn ainda continua a fazer parte do processo, entretanto apenas com o banco viral. Complementando a analise, é utilizada uma abordagem baseada em BLASTx com o software Diamond. O uso do Diamond é relacionado com o uso de banco completo que pode classificar um arquivo completo de 5 á 6 horas e a similaridade é baseada em proteínas. Para este parte do processo utilizamos uma nova abordagem conhecida com Docker.

O Docker é uma alternativa de virtualização do KERNEL (componente central do sistema operacional) de uma máquina seja ela Windows ou Linux. O KERNEL é 
compartilhado com a máquina virtualizada, portanto um desenvolvedor pode agregar a seu projeto, script ou software a possibilidade de utilizar as bibliotecas e outras dependências que fazem este sistema funcionar corretamente com menos perda de desempenho. Outro ponto importante é que isso evita atualizações automáticas que muitas vezes em certos softwares vem com alguns problemas a serem corrigidos até sua consolidação. O Docker pode ser compartilhado com outras pessoas sendo que pode serutilizado em qualquer máquina sem instalação prévia de nenhuma das dependências ou bibliotecas. Desta forma utilizamos o Diamond na forma de Docker para termos uma menor perca e gasto computacional.

\subsection{Diversidade viral encontrada em amostras de plasma}

\subsubsection{Análise da comunidade viral não patogénica}

Dentre os vírus não patogénicos (comensais) encontrados em todos os pools podemos destacar a presença dos vírus da família Anelloviridae. As espécies de anellovírus são altamente prevalentes e geneticamente muito diversas. Estes causam infeções virais crônicas em humanos que ainda não foram associadas a doenças. Pelo menos 200 espécies diferentes estão presentes em humanos e animais. Dentre algumas delas podemos destacar em nossos achados o TTMV 2, TTMV 5, TTMV 6, TTMV 7, TTMV 10, TTMV 11, TTMV 12, TTMV 13, TTMV 14, TTMV 15, TTV 11, TTV 12, TTV 15, TTV 16, TTV 17, TTV 20, TTV 22, TTV 25 e TTV 28.

Outro vírus comensal encontrado em nossas análises foi o GB vírus C (GBVC), anteriormente conhecido como vírus da hepatite G (HGV) e atualmente identificado como pegivírus humano do tipo 1 ( $\mathrm{HPgV}-1)$. HPgV-1 é um vírus da família Flaviviridae conhecido porinfectar seres humanos, mas não é conhecido por causar doença clínica. Os 11 pools analisados de Santa Maria-RS contia apenas vírus 
comensais (anellovírus e HPgV-1) e, portanto, nenhuma caracterização mais profunda foi executada tendo em vista esses resultados.

\subsubsection{Análise bioinformática de Amostras clínicas de doença pós-doação obtidasde doadores relatando DPD do Hemocentro de Ribeirão Preto/São Paulo,do ano epidemiológico de 2019/2020}

Inicialmente nós aplicamos a pipeline bioinformática em 10 pools derivados (76 amostras) de amostras com DPD provindas do município de Ribeirão Preto no estado de São Paulo de ano epidemiológico 2019/2020. A fim de deixarmos mais evidente e a título de apresentação denominamos nossos pools de P10, P11, P12, P21, P22, P05, P06, P20, P21 e P22 (conforme a ordem da sua elaboração e inclusão dos mesmos nos procedimentos de sequenciamento) de acordo com as tabelas apresentadas na seção "Materiais e Métodos". Abaixo segue umatabela com uma visão geral dos vírus com importância clínica identificados em cada um dos pools citados, a quantidade de reads e tamanho de contigs quando possível (Tabela 6).

Tabela 6. Representação dos pools analisados. Na tabela podemos verificar os vírus encontrados em cada pool assim como a quantidade de sequências recuperadas e contigsmáximos formados.

\begin{tabular}{llll}
\hline Pool & Vírus & Reads & Contigs \\
\hline P10 & DENV-2* & 23 & 239 \\
P11 & DENV-2 & 158 & 696 \\
P12 & DENV-2 & 2.084 .960 & 10.664 \\
P21 & Influenza A & 57 & 758 \\
P22 & Parvovírus B19 & 1.198 .765 & 4.256 \\
P05 & DENV-2 & 337 & 1.172 \\
P06 & DENV-2 & 654 & 2.365 \\
P20 & - & - & - \\
P21 & - & - & - \\
P22 & Citomegalovírus & 19 & - \\
& * Dengue vírus do tipo 2 & & \\
\multicolumn{2}{r}{ O primeiro pool analisado intitulado P10 apresentou 23 sequências de $D E N V$ - }
\end{tabular}

2, formando uma sequência máxima de 239 nucleótidos. No pool P11 o sequenciamento gerou 158 sequências, o contig máximo tinha 696 nucleótidos. O nosso maior número dereads foi obtido de pool P12 onde recuperamos 2.084.960 
sequências de $D E N V$-2. Após aplicação de métodos bioinformáticos específicos focados na recuperação do genoma, fomos capazes de extrair o genoma completo desta cepa com número de acesso no GenBank devidamente registrado sobre o número MN239505.

Com este achado começamos uma análise apurada do genoma isolado, primeiramente verificamos o genótipo da cepa, sendo que a mesma pertencia ao genótipo asiático/americano. Este fato era esperado sendo que a maioria das cepas atuais em circulaçãono Estado de São Paulo (principalmente as cidades de Ribeirão Preto, Araraquara e São José do Rio Preto) em sua maioria pertence a este genótipo. Para mais detalhes podemos consultar a Figura 9, onde destacamos a amostra de onde recuperamos o genoma completo.

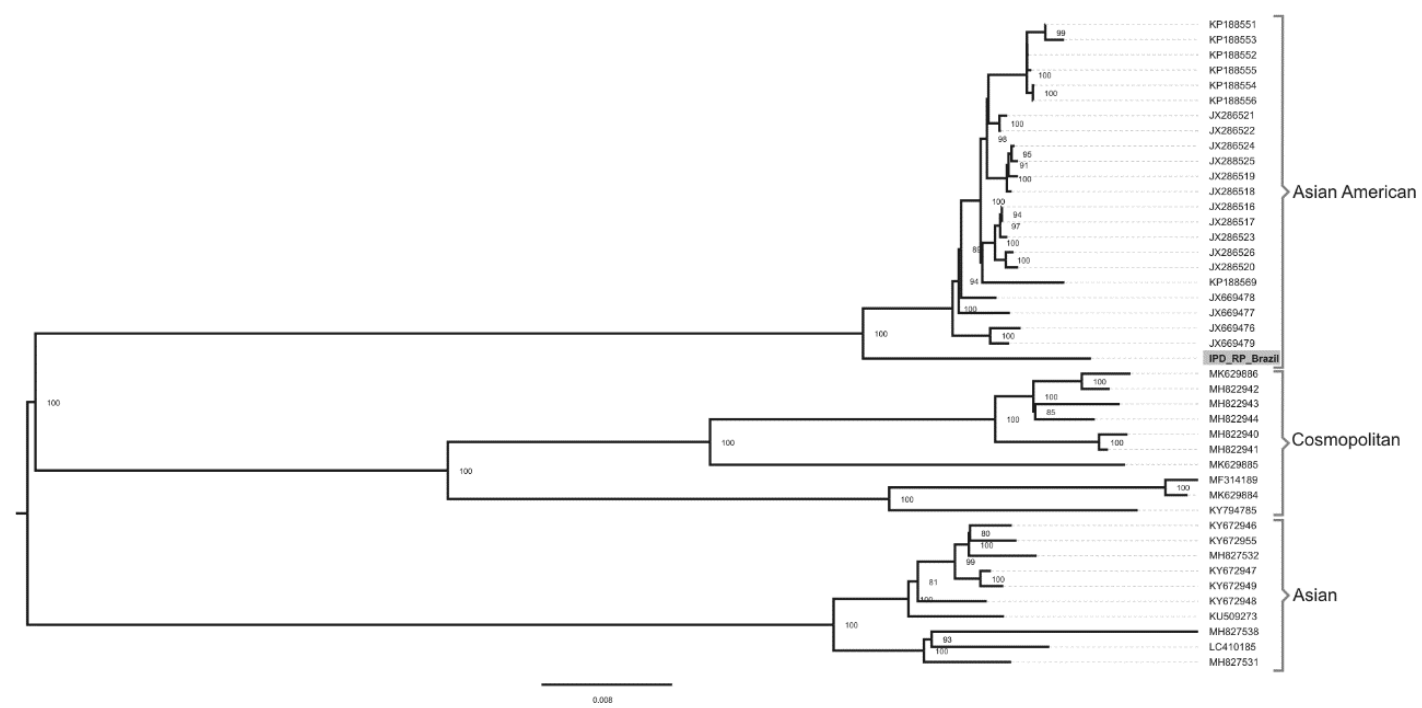

Figura 9. Análise filogenética do Dengue vírus 2 (DENV2). Apenas genomas completos foram utilizados para análise filogenética. $\mathrm{O}$ modelo de substituição de nucleotídeos utilizado foi o TIM2 $+\mathrm{F}+\mathrm{G} 4$ para a reconstrução da árvore, escolhido pelo modelo estatístico BIC (Critério de Informação Bayesiano), utilizando 10.000 réplicas de bootstrap ultrarrápidas para suporte estatístico dos ramos. Apenas valores acima de $75 \%$ foram demonstrados nos ramos da árvore. A árvore filogenética foi construída usando osoftware IQtree v.16.12, aplicando-se a abordagem de máxima verossimilhança. 
Desta maneira para complementar nossas análises e tendo em vista a informaçãoque pode ser retirada de um genoma completo, prosseguimos para a análise filogeográfica do isolado. Ao verificarmos a análise executada no pacote BEAST, podemos verificar que se tratava se uma cepa diferente dos genomas completos já publicados em bancos dedados como o ViPR e GenBank. Verificamos também a possível data de introdução desta cepa no contexto epidemiológico, que provavelmente é datada de 1999. Porém a posição basal do ramo (fora do clado) sugere uma possível falta de informação que pode ser corrigida com a análise de sequências parciais do envelope. Isso deve-se ao fato que nos bancos de dados nós temos uma grande quantidade de sequências do envelope que possam preencher esse gap comparando com genomas completos.

A nossa amostra se agrupa em um clado com cepas provindas do Brasil, assim indicando similaridade genética entre as cepas circulantes já isolados no país. Porém este genoma oriundo do nordeste brasileiro tem como cepa basal um isolado da República Dominicana, indicando que a possível introdução e disseminação destas cepas é das ilhas do Caribe. Este fato notavelmente indica a necessidade de mais informações e vigilância genômica dos surtos de DENV ocorridos no país. 


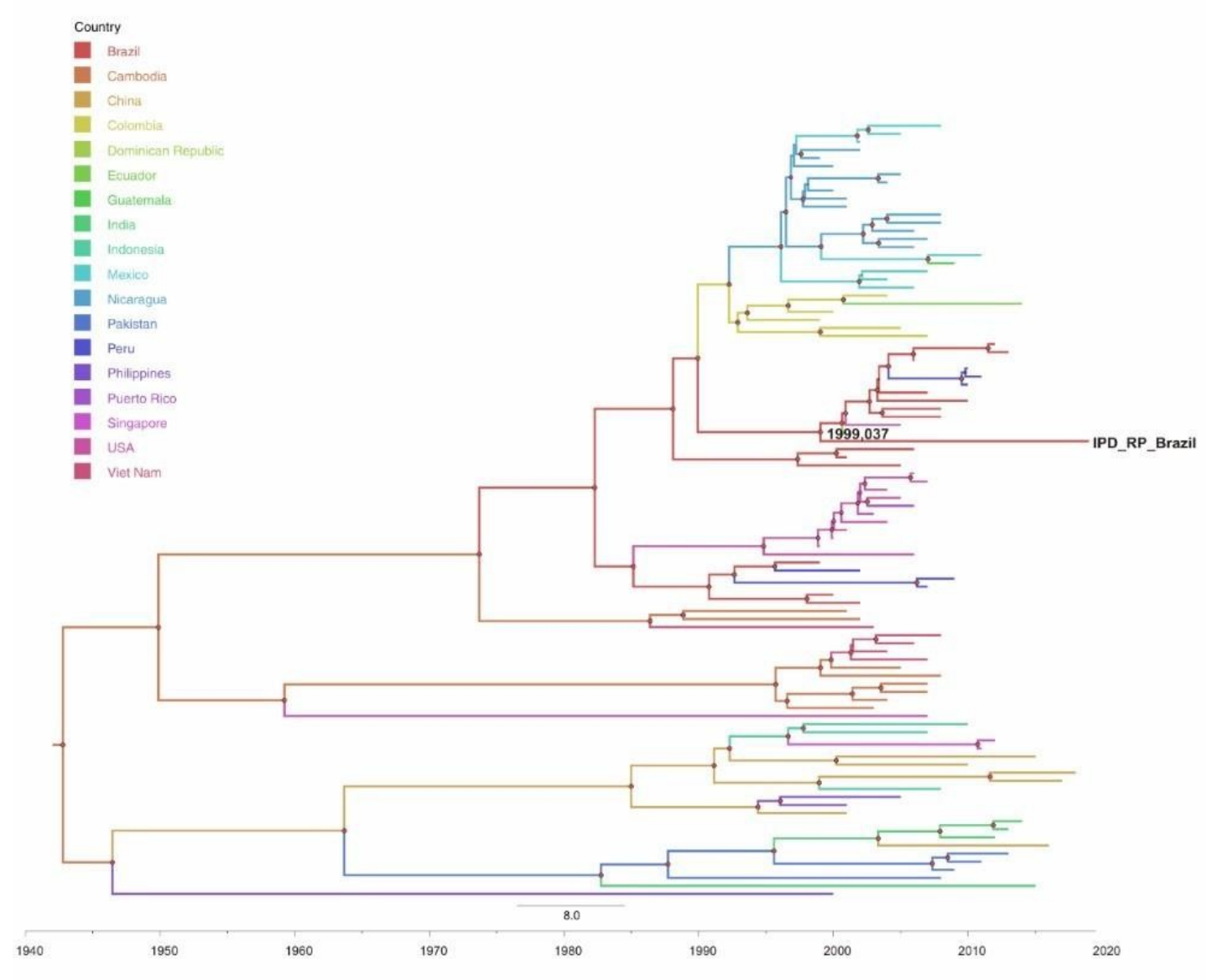

Figura 10. Árvore de credibilidade máxima do clado demonstrando as relações filogenéticas dos 96 genomas do Dengue vírus 2. Análise filogeográfica foi conduzida com o pacote BEAST versão 1.10.4, apenas probabilidades posteriores acima de 0.99 estão representadas nos ramos por círculos em vermelho.

A fim de corrigir essa distância genética contida nos ramos perante outras cepas (observar o distanciamento do ramo da Figura 10), utilizamos uma abordagem com apenas a parte do envelope das sequências (1.479 bp de região hipervariável do envelope da DENV-2) pela razão que temos mais sequências do envelope depositadas em bancos de dados biológicos do que genomas completos. Desta maneira fomos aptos para preencher as informações faltantes e assim termos uma reconstrução filogenética mais concisa. Como podemos observar na Figura 11, a nossa amostra se encontra em destaque. As camadas mais basais são providas da região do Caribe e 
América do Sul. No entanto, as amostras que estão no mesmo clado com a nossa amostra são do Caribe, assim comprovando reintrodução persistente nas Américas.

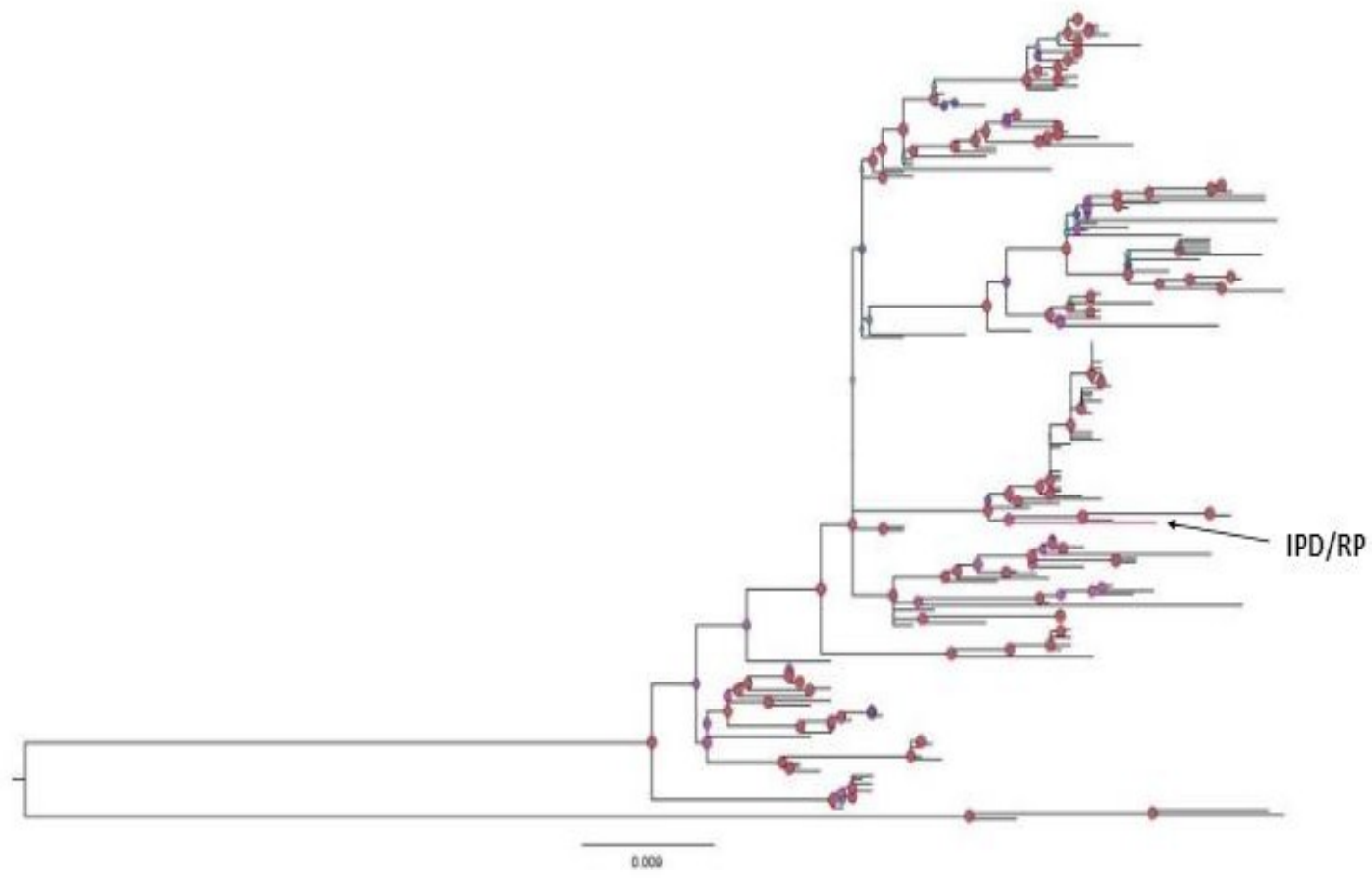

Figura 11. Análise filogenética do vírus da Dengue vírus 2 (DENV2). Apenas genomas do envelope foram utilizados para análise filogenética. O modelo de substituição de nucleotídeos utilizado foi o $\mathrm{TN}+\mathrm{F}+\mathrm{I}+\mathrm{G} 4$ para a reconstrução da árvore, escolhido pelo modelo estatístico BIC (Critério de Informação Bayesiano), utilizando 10.000 réplicas de bootstrap ultrarrápidas para suporte estatístico dos ramos. Apenas valores acima de $75 \%$ foram demonstrados nos ramos da árvore, valores mais próximos ou iguais a 100 se aplicam a cor vermelha, valores mais próximos ou iguais 75 se aplicam a cor azul. A árvore filogenética foi construída usando o software IQtree v.16.12, aplicando-se a abordagem de máxima verossimilhança.

Dando continuidade a análise das amostras de DPD em pool (P21) recuperamos e identificamos 57 sequências do vírus da Influenza A. O vírus da influenza A, ao contrário de outros, é formado por um genoma fragmentado em 8 diferentes partes identificadas como PB1, PB2, PA, HA, NP, NA, M e NS. Esta fragmentação torna a recuperação do genoma extremamente complexa. 
A fim de conseguirmos obter diferentes partes do genoma do vírus da Influenza Autilizamos uma abordagem de busca focada nas diferentes partes do genoma. Assim ao utilizarmos os fragmentos do genoma de referência e conseguimos recuperar partes distintas do mesmo. Dentre os achados podemos citar $758 \mathrm{pb}$ da região $\mathrm{PB} 2,252$ pb da região $\mathrm{M} 1 / \mathrm{M} 2,257$ da região $\mathrm{NP}, 707$ pb da região $\mathrm{PA}$ e por final 349 da região PA2.

Isso confirma um sequenciamento adequado do genoma do vírus da influenza A e a identificação in-silico de maneira muito robusta reforça este achado. Sendo que inicialmente na primeira abordagem fomos apenas capazes de identificar o fragmento PB2, ou seja, uma das regiões de maior conservação do vírus. Este achado reforça a importância de diferentes metodologias na análise bioinformática e como elas podem fazer a diferença na identificação de vírus com genomas de organização diferente. Desta maneira para uma investigação mais robusta executamos a confirmação direta do vírus da influenza A na amostra separada e a filogenia da região PB2. Além de confirmar a presença de RNA viral na amostra individual através de amplificação dos genes de HA e NA (HOFFMANN et al., 2001), nos realizamos a análise filogenética dos mesmos. As sequências consensos da hemaglutinina (477 pb) e neuraminidase (647 pb) foram alinhadas com o software MAFFT 7.0 usando um dataset obtido no GISAID (https: //www.gisaid.org), com cepas do Brasil que circularam durante os anos epidemiológicos 2011-2019. A análise filogenética foi feita com o software IQTREE 2.0 usando hemaglutinina (264 seqüências) e neuraminidase (419 sequências) aplicando os modelos de substituição $\mathrm{K} 3 \mathrm{Pu}+\mathrm{F}+\mathrm{G} 4$ e TVMe $+\mathrm{G} 4$. Os resultados demonstraram que a cepa se agrupou com isolados em circulação durante a temporada epidêmica de 2019 (Figura 12). A sequência de hemaglutinina (HA) foi depositada no GenBank sob o número de acesso MT126243 e a sequência de 
neuraminidase sob o número de acesso MT126244. As árvores filogenéticas da HA e NA são apresentadas na Figura 12. 

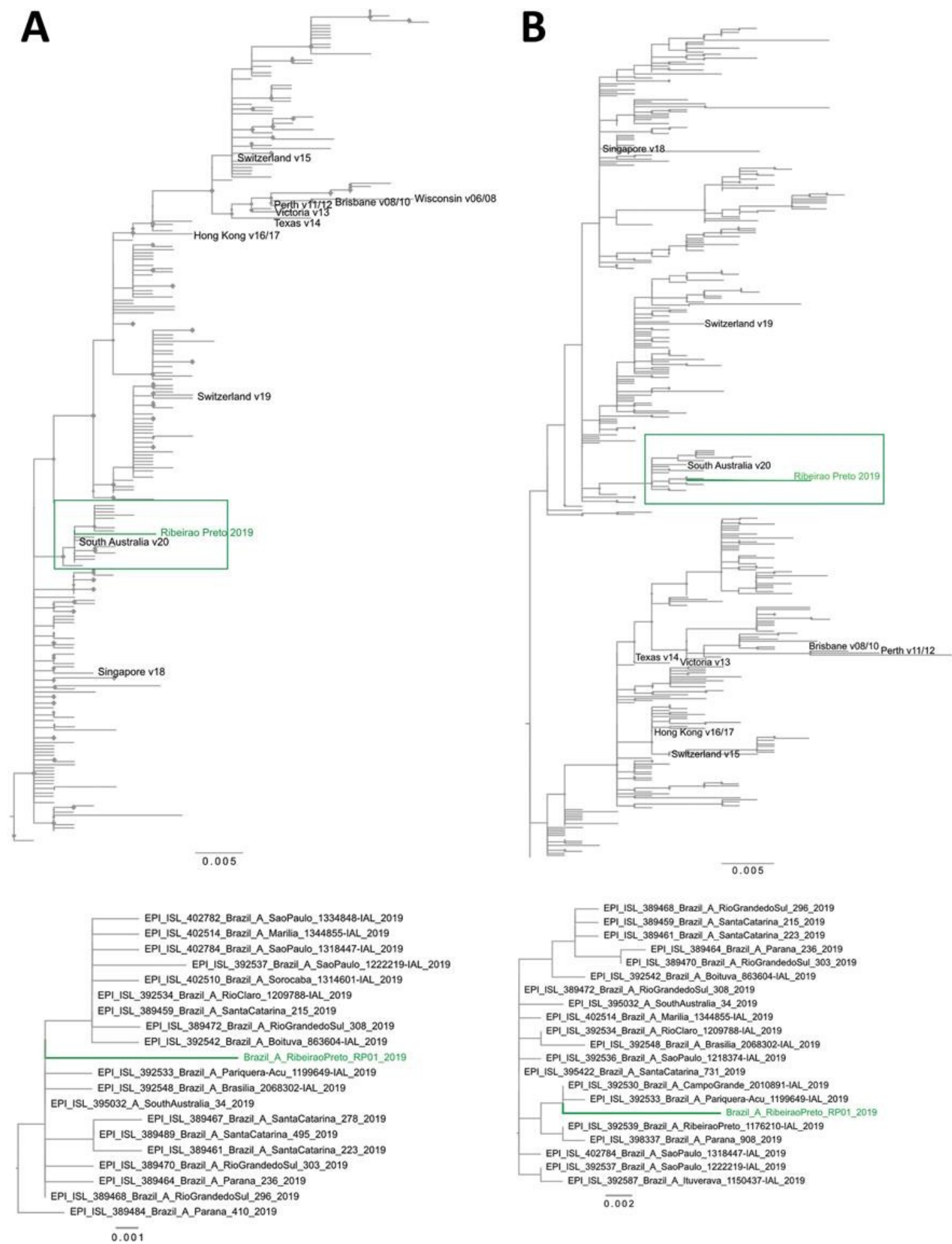

Figura 12. Árvore filogenética de máxima verossimilhança da hemaglutinina (A) e neuraminidase $(B)$ do vírus influenza A (H3N2) detectado em doação de sangue. A cor verde indica a cepa H3N2 obtida do doador de sangue de Ribeirão Preto; diamantes em cada nó indicam suporte estatístico ao longo dos ramos definidos com bootstrapping ultra- rápido $>90 \%$ (de 10.000 réplicas). O cluster onde está localizada a cepa obtida de Ribeirão Preto é mostrado em detalhes na parte inferior. 
No pool P22 também oriundo do Hemocentro de Ribeirão Preto encontramos uma alta quantidadede sequências do B19V. Ao todo encontramos 1.198.765 de sequências e com a posterior montagem conseguimos recuperar uma grande parte do genoma do vírus. Em média o genoma completo do B19V tem 5.596 nucleótidos, desta maneira recuperamos 4.256 nucleótidos em uma única sequência.

Para confirmarmos o genótipo do nosso isolado optamos pela reconstrução filogenética do mesmo. A nossa análise demonstrou que a cepa infectante foi classificada genótipo 1 , subgenótipo $1^{\text {a }}$ que o genotipo mais prevalente no Brasil. A cepa identificada se agrupou entre cepas isoladas no Brasil em um estudo de 2013 e com uma cepa circulante nos EUA no mesmo ano (para mais informações verificar Figura 13).

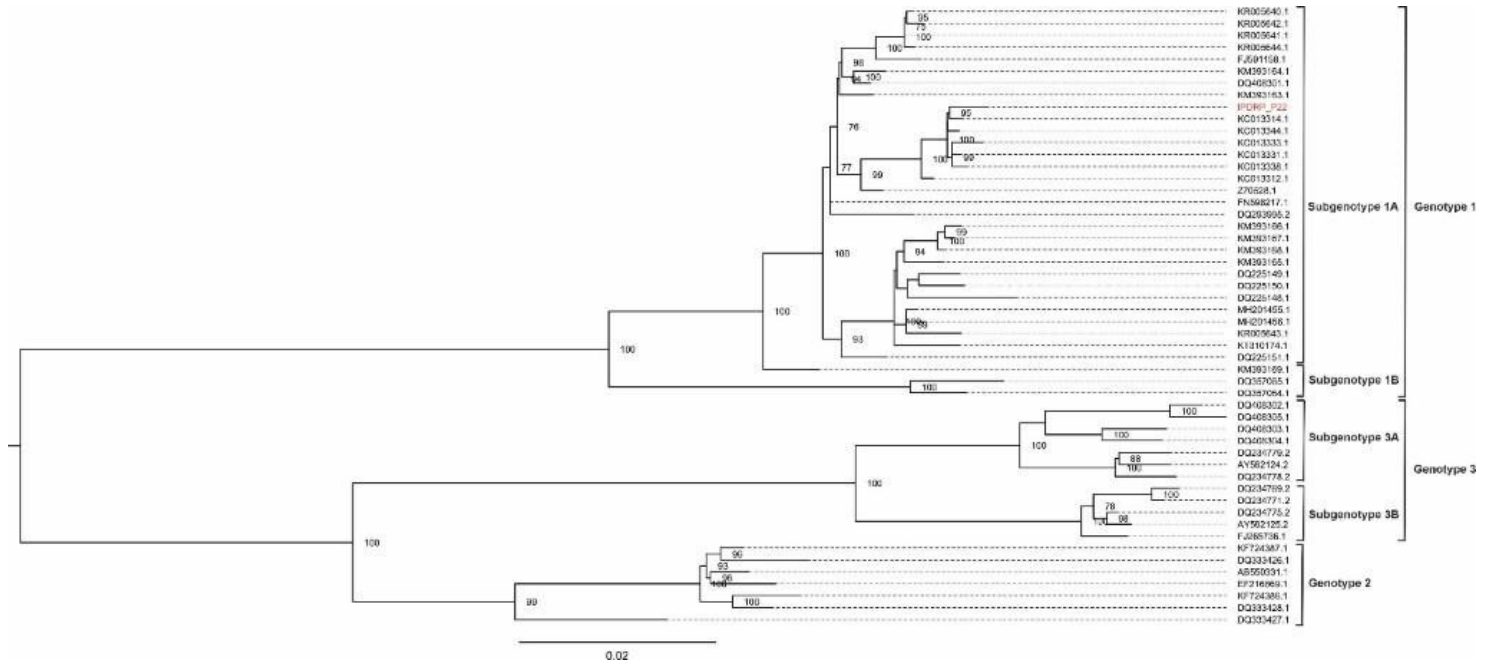

Figura 13. Análise filogenética do Parvovírus humano B19. Apenas genomas completos foram utilizados para análise filogenética. $O$ modelo de substituição de nucleotídeos utilizado foi o $\mathrm{TN}+\mathrm{F}+\mathrm{R} 2$ para a reconstrução da árvore, escolhido pelo modelo estatístico BIC (Critério de Informação Bayesiano), utilizando 10.000 réplicas de bootstrap ultrarrápidas para suporte estatístico dos ramos. Apenas valores acima de $75 \%$ foram demonstrados nos ramos da árvore. A árvore filogenética foi construída usando o software IQtree v.16.12, aplicando-se a abordagem de máxima verossimilhança. 
Dos pools que foram encontrados vírus clinicamente importantes podemos destacar 05 e 06 do ano epidemiológico de 2020. No pool 05 encontramos 337 sequências pertencentes ao DENV-2 e conseguimos recuperar uma sequência parcial do genoma de 1.172 pares de base. No pool 06 fomos aptos para recuperar 654 sequências também pertencentesao DENV-2 e conseguimos montar uma sequência parcial de 2.365 pares de base. Por fim analisamos os pools 20, 21 e 22 provenientes do ano epidemiológico de 2020. Os pools 20 e 21 não apontaram a presença de nenhum vírus potencialmente causador de DPD, sendo encontrado apenas vírus órfãos como o GBV-C e diferentes espécies de anellovírus. Entretanto o pool 23 apresentou 19 reads pertencentes ao Citomegalovírus pelo qual que pode ser uma possível causa de DPD.

\subsubsection{Análise metagenômica de bolsas de sangue provenientes de doadores infetados com HIV, HBV, HCV, HTLV, doença de Chagas e sífilis da regiãoAmazônica}

Neste trabalho analisamos 12 pools (58 doações) compostos de amostras de doadores de sangue infectados com agentes rotineiramente triados pelos bancos de sangue da região amazônica do Brasil. Da mesma maneira que fizemos anteriormente dividimos nossas análises em pools identificados de P23 a P26, P36-P38, e P15-P19 (da mesma forma igual os pools de Ribeirão Preto a ordem desses pools apresenta o tempo de manipulação bem como o equipamento utilizado). Abaixo podemos verificar como mais detalhes na Tabela 7 a distribuição dos vírus por cada pool. 
Tabela 7. Representação dos pools obtidos da região Amazônica brasielira de doadores infectados com HIV, HBV, HCV, HTLV, Trypanosoma cruzi, e sífilis. analisados. Na tabela podemos verificar os vírus encontrados em cada pool assim como a quantidade de sequências recuperadas e contigs máximos formados.

\begin{tabular}{llll}
\hline Pool & Vírus & Reads & Contigs \\
\hline P38 & HIV-1 & 449 & 307 \\
P15 & HBV & 687 & 707 \\
P16 & - & - & - \\
P17 & HuGvK2 & 88 & - \\
P18 & HIV-1 & 39 & - \\
P19 & HIV-1 & 63 & - \\
& & & \\
& GcV & 772 & 1.056 \\
& Adenovírus 7 & - & 372 \\
& Ciclovírus NG14 & - & 303 \\
P24 & HCV & 4.044 & 1.023 \\
& HBV & 442 & 556 \\
P25 & HIV-1 & 5.742 & 702 \\
P26 & HuGvK2 & 61 & - \\
& GcV & 47 & - \\
& HIV-1 & 47 & - \\
P36 & HBV & 3.928 & 1.050 \\
& Merkel & cell & 5.970 \\
& polyomavirus & & 5.464 \\
& HIV-1 & 81 & - \\
P37 & HIV-1 & 549 & 407
\end{tabular}

Em pool identificado como P23 encontramos vírus emergente de grande interesse e com patogénese muito pouco estudada. Primeiramente observamos 772 sequências pertencentes ao Gemykibivírus huamno 2 (HuGvK2) e de maneira igual o Gemycircularvírus humano (GcV) com 772 sequências também (família Genomoviridae). Após passarmos pelo processo de montagem do genoma conseguimos recuperar uma sequência de 750 nucleótidos do HuGvK2 e de 1056 nucleótidos do GcV. Também identificamos uma sequência com 372 nucleótidos pertencente a Adenovírus tipo 7, assim com 303 nucleótidos pertencentes ao Ciclovírus NG14. Posteriormente continuamos a análise com os pools P24 e P25 onde identificamos no P24 4.044 sequências do vírus da Hepatite C e 442 do vírus da 
Hepatite B. Já no pool 25 identificamos 5.742 sequências pertencentes ao HIV-1. Os últimos agentes virais já eram esperados devido ao fato que as doações foram obtidas de doadores de alto risco positivas para as infecções supracitadas. Isso pode ser observado na Tabela 7 onde quase todos os pools contém sequencias virais conhecidas.

Da mesma maneira ao investigarmos o pool P26 conseguimos recuperar também sequencias do HuGvK2, porém nesta vez em menor quantidade, com um total de 61 sequências. Havia também 47 sequências pertencentes ao HIV-1 que já tinham sido anteriormente confirmadas por reações sorológicas. .

A fim de obtermos maiores informações sobre o HuGvK2, utilizamos a reconstrução filogenética para confirmarmos a veracidade de nosso achado. A nossa amostra em destaque se alocou junto com o clado do tipo 2, o que já era esperado, porém apresentou um ramo evolutivo curto indicando alta similaridade. Esta reconstrução nos confirma que a cepa pertence aos tipos que circulam na população humana (para detalhes consultar Figura 14). As análises filogenéticas do HuGkV-2 foram realizadas usando um dataset de genomas completos obtidos de NCBI (https://www.ncbi.nlm.nih.gov/). Para elucidar as diferenças entre os vírus que compõem a família Genomoviridae, os dados foram compostos por diferentes amostras obtidos de animais, meio ambiente e seres humanos. Também incluímos os vírus gemicirculares (filogenéticamente próximos ao HuGkV-2) para avaliar a divergência genética em comparação com o HuGkV-2 que foi identificado. O alinhamento foi realizado pelo software MAFFT v.7.429 e o sinal filogenético foi avaliado pelo programa Tree Puzzle v.5.2. Para reconstruir a história filogenética dos vírus identificado, usamos o software IQtree v.16.12, aplicando o método de máxima verossimilhança. 
A

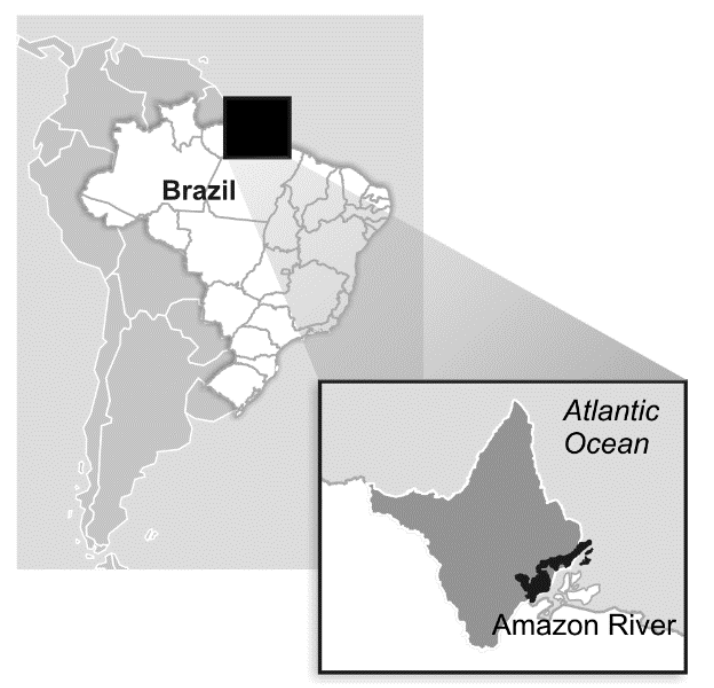

B

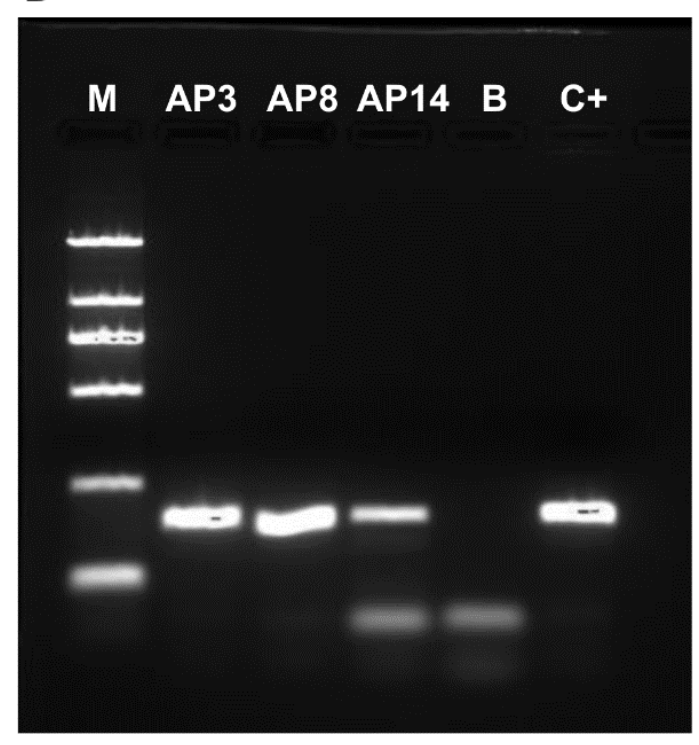

C

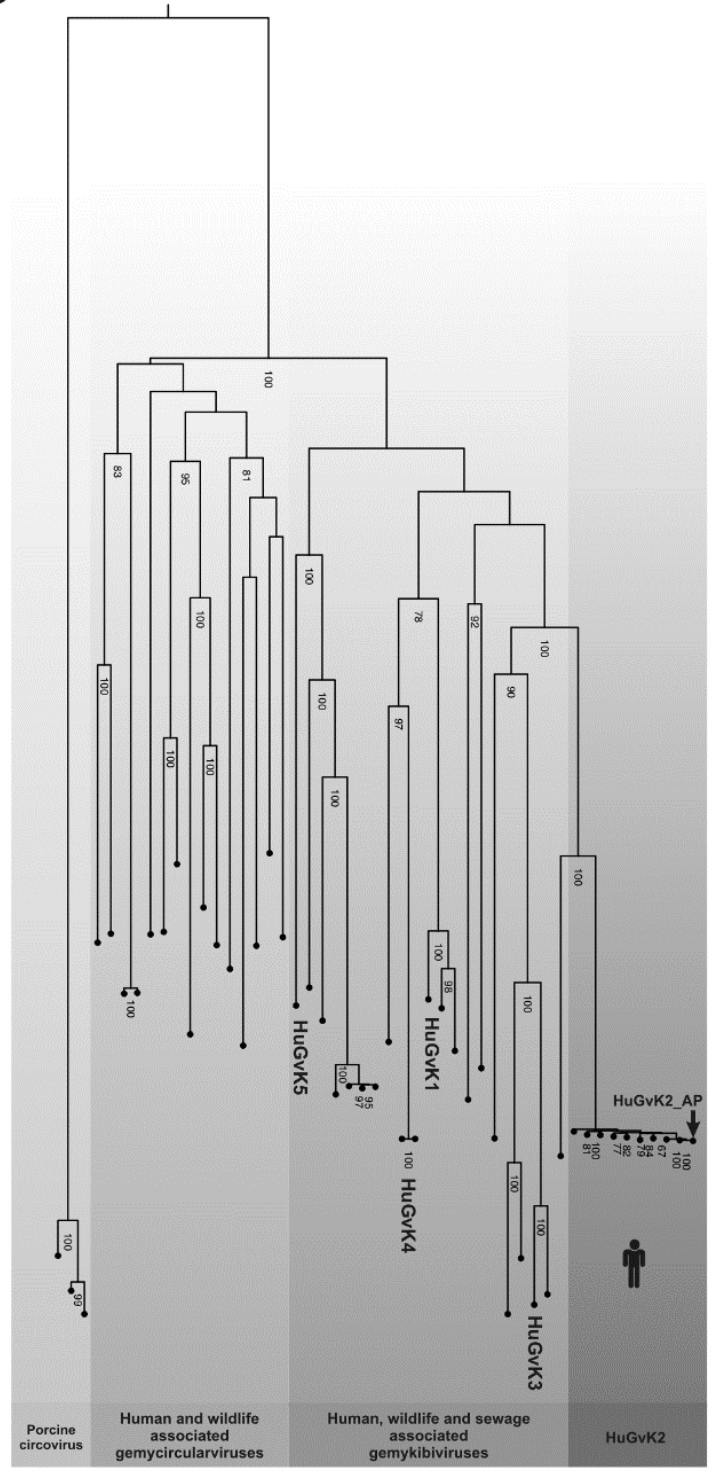

Figura 14. Identificação do Gemykibivirus-2 humano em amostras de doadores de sangue da Amazônia com infecções parentéricas. A. Localização geográfica da cidade de Macapá, no estado do Amapá, na Amazônia brasileira. B. Eletroforese em gel das três amostras positivas obtidas de doadores de sangue da Amazônia (AP3, AP8 e AP14). Outras abreviações: $M$, escada molecular; B, amostra em branco e $C+$, controle positivo. C. Análise filogenética do gemykibivirus-2 humano (HuGkV-2). O modelo de substituição nucleotídica utilizado foi o $\mathrm{HKY}+\mathrm{F}+\mathrm{R} 5$ para reconstrução da árvore e foi escolhido de acordo com o modelo estatístico BIC (Critério de Informação Bayesiano), utilizando 10.000 réplicas de ultrafast bootstrap para significância estatística. Apenas valores acima de $75 \%$ são demonstrados nos ramos da árvore. 
Nos pools P36, P37 e P38 conseguimos identificar 549 sequencias pertencentes ao HIV-1 (pool 37) e 3.928 sequencias de HBV (pool 36). Porém a deteção destes vírus já era esperada devido ao fato que foram testadas bolsas de sangue positivas para os mesmos. Surpreendentemente no pool 36 além do HBV também conseguimos recuperar o genoma completo (5.464 pb) do Merkel cell poliomavírus (MCPyV) com alta cobertura de $\sim 233 X$. Interessantemente este vírus já descrito com cargas mais altas em pacientes HIV positivos foi encontrado com possível carga alta em um pool onde apenas continha pacientes positivos para HBV. Este achado demonstra que MCPyV pode ter comportamento de vírus oportunista bem como ter impacto na medicina transfusional. Por fim no Pool 38 também identificamos 449 sequencias pertencentes ao HIV-1 que também já tinha sido confirmado por reações sorológicas.

A fim de melhor caracterizar o genoma do MCPyV encontrado no pool $36 \mathrm{e}$ identificar sua história evolutiva executamos algumas análises filodinâmicas e populacionais da cepa isolada. A análise filogenética do MCPyV identificado foi realizada usando conjuntos de dados de 115 genomas obtidos do NCBI (https://www.ncbi.nlm.nih.gov/), (21 dos EUA, 1 da Suécia, 1 da Suécia, 1 da Lituânia, 3 da França , 20 da Argentina, 9 do Brasil, 17 da Espanha, 23 do Uruguai, 3 da Guiana Francesa, 1 da Colômbia, 1 da Nova Caledônia, 5 da Costa do Marfim, 5 do Congo e 5 do Japão), truncados na região VP1 do genoma.

O modelo de substituição nucleotidíca surgeirdo pelo Modeltest foi o HKY + 4G de acordo com oBIC (Critério de Informação Bayesiano). A árvore inicial gerada foi usada como partida para a análise filogenética em escala temporal usando o BEAST v.1.10.2. Utilizamos o modelo de substituição HKY $+4 \mathrm{G}$ e um de modelo de coalescência bayesiana conhecidocomo skygrid. Nós computamos as Cadeias de Markov Monte Carlo (CMMC) em corridas duplicadas de 50 milhões de estados 
cada. A convergência das cadeias CMMC foram verificadas usando o programa Tracer v.1.7.1. Para visualização da árvore e sua edição, usamos o FigTree v. 1.4.

Desta maneira realizamos análises filodinâmicas onde podemos observar uma árvore reconstruída em função das substituições nucleotídicas, tempo e origem geográfica. Interessantemente podemos ver que os clados em sua maioria se agrupam por sua origem geográfica, e isso foi esperado devido ao fato que se trata de um vírus de DNA com baixa taxa de diversidade genética. Porém em destaque na Figura 15, interessantemente a nossa amostra demonstrou uma posição basal em comparação ao isolado colombiano também obtido da Amazônia o que indica que provavelmente o vírus teve origem brasileira antes de se disseminar para Colômbia. 


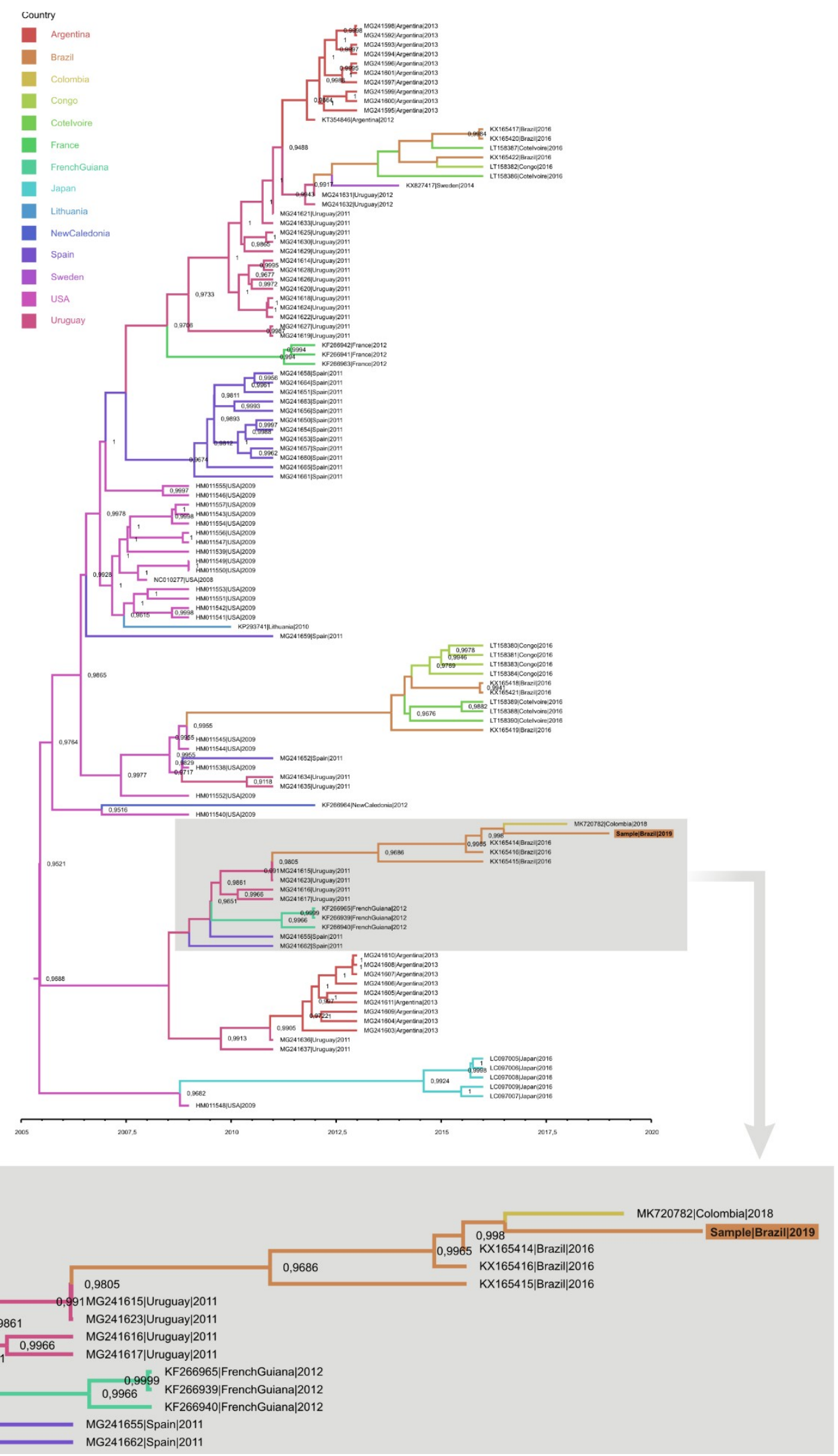


Figura 15. Árvore filogeográfica de diferentes isolados do Merkel cell poliomavírus. Ao total utilizamos 115 cepas para descrever a trajetória temporal/geográfica do vírus até nossa cepa. A foi gerada em escala temporal usando o programa BEAST v.1.10.2, com omodelo de substituição HKY + 4G mais modelo de coalescência bayesiana skygrid. Emdestaque temos o clado onde se encontra o nosso isolado. O suporte estatístico é demonstrado nos ramos da árvore.

A linguagem de programação $\mathrm{R}$ foi utilizada para conduzir as análises da matriz de distância populacional entre as linhagens americanas, a fim de inferir diferenças sobre essa população específica. Após verificarmos e gerarmos os gráficos populacionais de nossa amostra conseguimos verificar que se tratava de um uma cepa com origem comum a maioria dos isolados da América do Sul. Como podemos verificar no gráfico de densidade a nossa cepa se encontra em destaque com a seta vermelha (Figura 16). A nossa cepa segue o padrão que a maioria dos isolados de origem europeia, porém o gráfico demonstra algumas cepas com maior divergência populacional o que pode ser explicadopor diferentes origens como a africana.

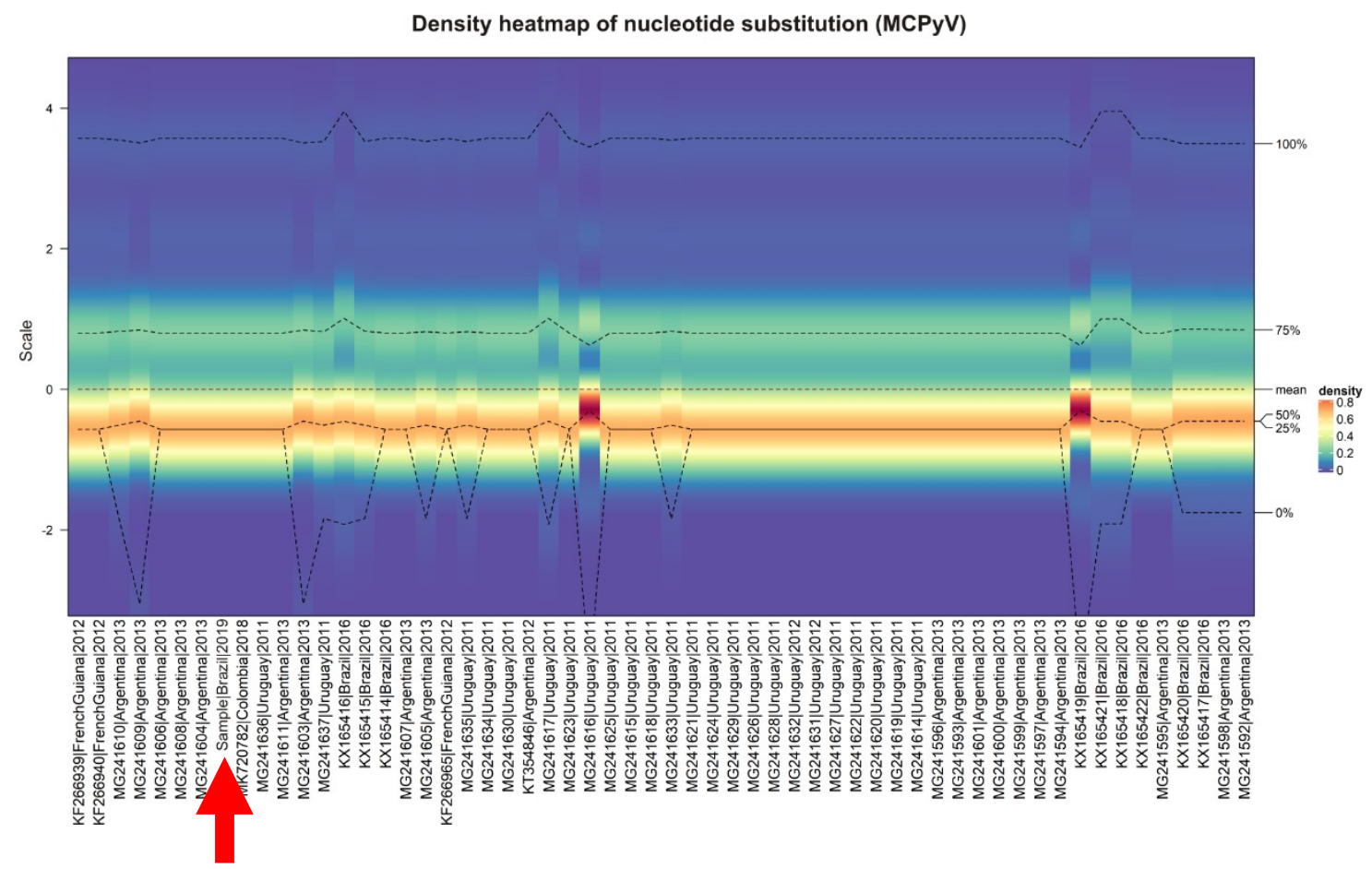


Figura 16. Mapa de calor baseado em divergência populacional. Podemos verificar que o nosso isolado destacado pela seta vermelha segue o padrão das maiorias das cepas encontradas na américa do sul ou seja tendem a ter a mesma origem geográfica possivelmente europeia e as cepas de possível origem africana em minoria se destacam no mapa com maior densidade.

Por fim analisamos os pools 15 a 19. O pool 15 apresentou assim como já esperado 687 reads pertencentes ao HBV, assim como o pool 15, 18 e 19 que apresentaram HIV-1 com 39 e 63 reads respetivamente. O pool 17 apresentou 88 reads pertencente ao HuGvK2, porém diferentes das outras amostras onde conseguimos recuperar fragmentos maiores do genoma e portanto neste caso não foi possível assim impedindo uma caracterização mais profunda. No pool 16 não foi possível identificar nenhum vírus de interesse a ser caracterizado, porém podemos verificar altos números de reads pertencentes ao $\mathrm{HPgV}-1$ e uma ampla gama de anellovírus.

\subsubsection{Estudos sobre pools de Ribeirão Preto obtidos durante surto de ZIKV/DENV em 2019 e pools com DPD de São Paulo, SP em 2019.}

Por fim analisamos pools pertencentes a DPD de Ribeirão Preto do ano de 2016 (Pools 7-10) e do Hospital Israelista Albert Einstein, São Paulo de 2019 (Pools 1-4). Comumente, nestas amostras conseguimos identificar em o HPgV-1 bem como diversos tipos da família Anelloviridae, dentre alguns deles podemos destacar em nossos achados o TTMV 1, TTMV 4, 5, 7, 8, 11 - 15, TTV 11, 12, 15, 16, 22, 25 e 28. As amostras de DPD provenientes de São Paulo-SP apresentaram apenas vírus comensais e múltiplos fagos e por isso analisas mais profunda não foram executadas.

Vale destacar que todas as amostras do ano epidemiológico de 2016 foram obtidas durante um surto extenso de DENV / Zika vírus (ZIKV) na cidade de Ribeirão Preto-SP e amostras que previamente testaram positivo para RNA de DENV e ZIKV foram retiradas da análise metagenômica para não haver interferência no resultado final de identificação de possíveis agentes virais que co-circularam nesse período. 
Durante a análise metagenômica destes pools acima citados, além dos vírus comensais já citados também observamos um alto número de leituras pertencentes a fagos de Pseudomonas spp. A diversidade de fagos pode ser um indicador indireto da presença de infecção bacteriana pronunciada nas amostras de plasma testadas. Também identificamos outros fagos que infectam bactérias Bacillus, como o vírus Bacillus G e vírus gigantes, incluindo o Orpheovirus. Em três pools (7, 8 e 10), também foram identificadas reads pertencentes ao Vírus iridescente de invertebrados 6 com 2966, 145 e 214 reads, respetivamente (Figura 17). O interessante é que este vírus infecta amplamente insetos e predominantemente mosquitos. Uma pesquisa adicional com o uso do software BLAST demonstrou que essas reads pertenciam ao gene 392R do genoma do vírus iridescente. 
A

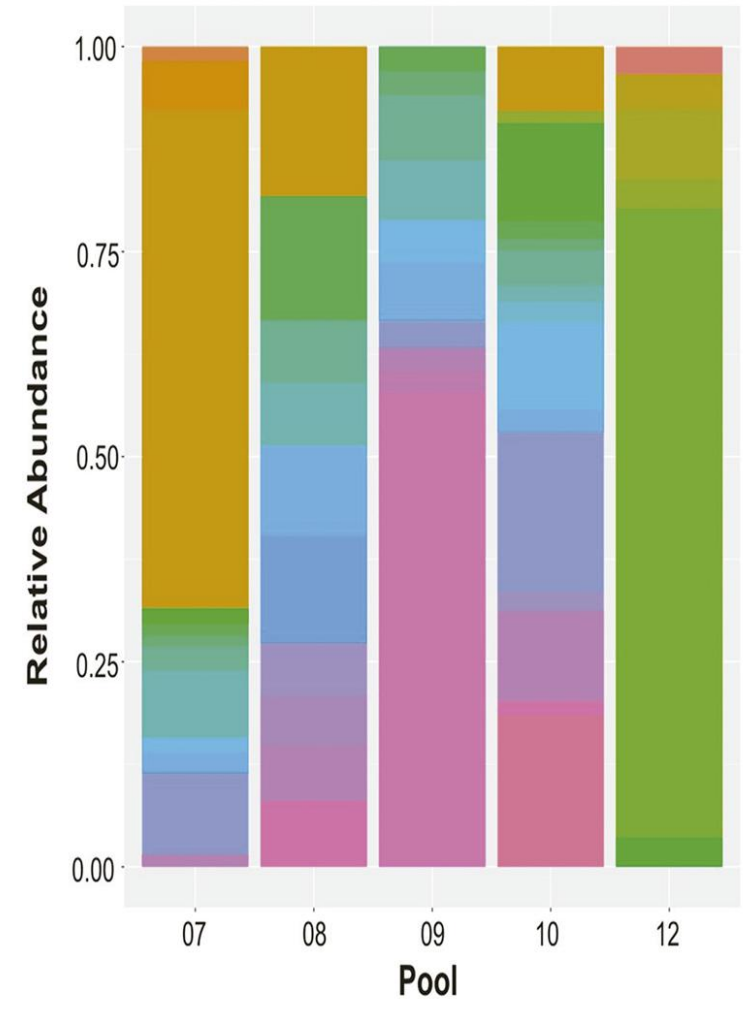

B

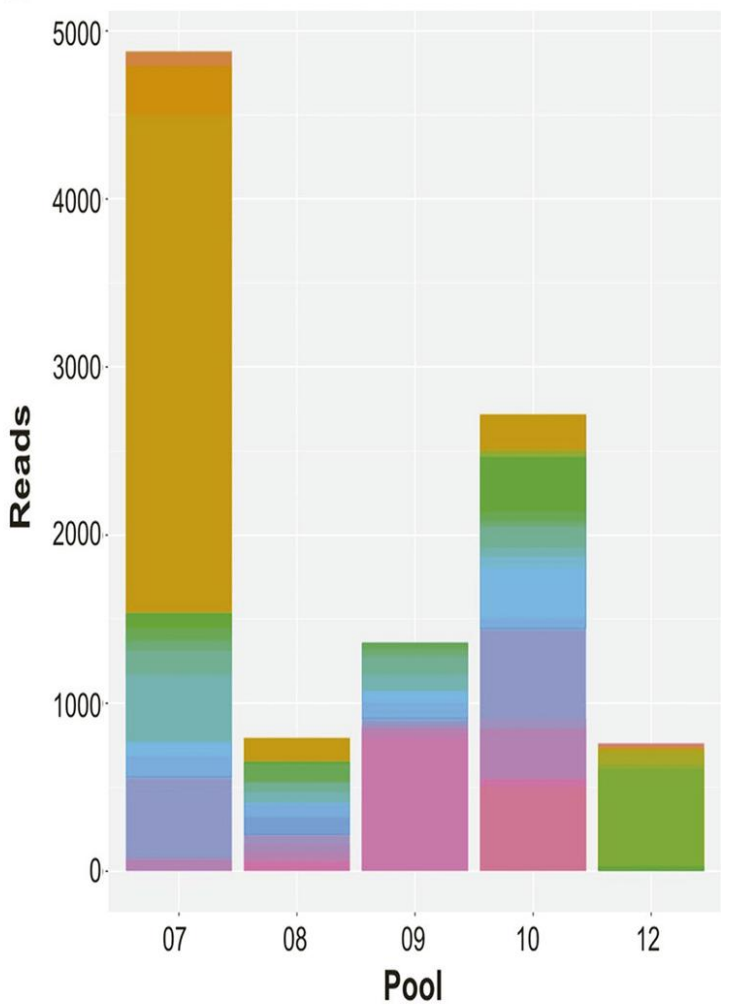

\begin{tabular}{|l|l|}
\hline Virus & \\
\hline Acanthamoeba polyphaga moumouvirus & Torque teno virus 15 \\
\hline Apocheima cinerarium nucleopolyhedrovirus & Torque teno virus 16 \\
\hline Bacillus virus $G$ & Torque teno virus 19 \\
\hline Invertebrate iridescent virus 6 & Torque teno virus 20 \\
\hline Megavirus chiliensis & Torque teno virus 24 \\
\hline TTV-like mini virus & Torque teno virus 27 \\
\hline Orpheovirus IHUMI-LCC2 & Torque teno virus 28 \\
\hline Torque teno mini virus 5 & Torque teno virus 29 \\
\hline Torque teno virus & Torque teno virus 3 \\
\hline Torque teno virus 10 & Torque teno virus 5 \\
\hline Torque teno virus 11 & Torque teno virus 8 \\
\hline Torque teno virus 12 & Pseudomonas virus TL \\
\hline Torque teno virus 13 & \\
\hline D
\end{tabular}

Figura

Figura 17. Gráfico de barras ilustrando a abundância relativa e absoluta de vírus encontrados nos pools testados de amostras de plasma. No eixo dos $\mathrm{X}$ é expresso o número de pools testados: A) Abundância relativa de vírus encontrados nos pools analisados; B) Abundância absoluta em relação ao número de leituras virais encontradas nos pools testados. A alta abundância do Vírus iridescente de invertebrados 6 pode ser 
observada no pool número 07 , ao qual pode ser atribuída uma transmissão passiva dos mosquitos vetores circulantes durante o surto de arbovírus testado. 


\section{DISCUSSÃO}

Os passos antecedentes a doação de sangue como a entrevista e exames diagnósticos de doenças infeciosas de cunho obrigatório garantem a segurança transfusional dos hemoderivados para os receptores de sangue. Porém sabemos que dentro deste processo pode haver alguns erros incluindo omissão de informações pelos doadores. Quando o doador voluntariamente volta a comunicar essa informação omitida no ato da doação é denominada informação pós-doação como IPD (WILKINSON et al., 2011). No entanto, alguns doadores desenvolvem sintomas adversos devido geralmente a alguma doença infectocontagiosa após a doação e quando esses eventos são comunicados também são referidos como doença pós-doação ou DPD (GOLDMAN et al., 2006). Neste sentido a informação pós-doação difere de DPD onde o doador não intencionalmente omitiu informações.

Muitas vezes DPD chega aos bancos de sangue dias após a doação, mas muitos casos de DPD não são notificados ou nem mesmo descobertos até que várias doações tenham ocorrido (OFFERGELD e HEIDEN, 2017). O nosso estudo tenta a verificar se ainformação obtida após a doação de sangue referente a doença infecciosa ou DPD pode ser relacionada com algum agente viral sendo que a bolsa com informação pósdoação é geralmente descartada. A nossa opinião é que DPD é importante porque nós detectamosagentes virais patogênicos que podem ser transmitidos via transfusão de sangue e causardoenças graves em receptores de produtos sanguíneos. Na nossa análise nós detectamos vírus de extrema importância como DENV-2, B19V e Influenza A. Neste contexto podemos discutir os nossos achados da DENV-2 pois trata-se de uma infeção bem definida na literatura como transmitida via transfusão de sangue. Estudos no Brasil, Honduras e Porto Rico demonstraram a presença assintomática da viremia da DENV-2 em doadores de sangue acima de 50\% 
(MOHAMMED et al., 2008; LINNEN et al., 2008; SABINO et al., 2012). O primeiro caso publicado de dengue transmitida pela transfusãoocorreu em Hong Kong em 2002. O doador tornou-se sintomático após um dia depois da doação e o paciente transfundido desenvolveu sintomas da doença 3 dias após a transfusão (CHUANG et al., 2008). Outro caso de grande repercussão na literatura trata de um casode DENV-2 transfusional em Singapura. Onde um doador de sangue, assintomático com 52 anos de idade, doou sangue em 15 de julho de 2007. O receptor da bolsa teve febre e mialgia 2 dias após a transfusão, que posteriormente por PCR foi confirmada a presençade DENV-2 (TAMBYAH et al., 2008). Casos transfusionais de DENV estão sendo registrados também na nossa região () o que reforça os nossos achados e a importância desta infecção no Brasil.

Desta forma a possibilidade de transmissão de dengue em países endémicos se torna de extrema importância, sendo que pode acarretar graves consequências clínicas importantes a pessoa transfundida. Ao analisarmos bolsas com DPD conseguimos recuperar o genoma completo de uma cepa que se distância das já notificadas comparada com os bancos de dados biológicos. Isso demonstra a importância da vigilância genômica e das informações disponíveis em bancos de dados públicos para identificar mutações e possíveis caminhos de surtos epidemiológicos. Outro aspecto importante é que a amostra não provém de um surto epidemiológico da cidade de Ribeirão Preto, sendo que neste ano não houve surto na cidade, confirmando a participação das áreas adjacentes com surto de DENV no processo transfusional de áreas sem epidemias.

Ainda não menos preocupante para medicina transfusional é o B19V que pode ser transmitido via transfusão de sangue incluindo com consequências graves para o receptor (NAGAHARU et al., 2017). O B19V é o agente causador da quinta doença 
emcrianças, que é uma doença benigna (ANDERSON, JONES e FISHER-HOCH, 1983 ) e está associado a doenças reumatológicas em adultos (REID, et al., 1985). Em pacientes com anemia hemolítica, pode causar crise aplástica da medula óssea grave conhecida como TAC (transient aplastic crisis, crise aplástica transitória) (RAO, MILLER e COHEN, 1992), e em pacientes imunossuprimidos, causa aplasia eritrocitária persistente (KURTZMAN et al., 1989). Na gravidez sua infeção pode resultar em hidropisia fetal e aborto espontâneo (TSUJIMURA et al., 1985). Perante a grande variedade de doenças ligadas ao B19V e aos danos que pode causar ao paciente transfundido torna se importante a avaliação da presença desse vírus em bolsas de sangue. Como nós conseguimos recuperar o genoma completo do vírus acreditamos que se trata de uma carga viral alta $(\mathrm{Ct}=20$, após confirmação com PCR em tempo real) que pode resultar em sintomas clínicos no receptor. Transmissão transfusional do B19V já foi descrita e relacionada a severa trombocitemia e, portanto, medidas para diminuir o risco transfusional desse agente viral são essenciais (NAGAHARU et al., 2014). Infelizmente no Brasil esta infecção não é triada rotineiramente, apesar de alguns países europeus aplicam a testagem molecular para DNA do B19V em fatores de coagulação derivados de plasma humano. Na nossa análise filogenética detectamos que nossa amostra se agrupou no clado pertencente ao subgenótipo 1A. Como é bem sabido e destacado em alguns estudos este genótipo pode ser encontrado mundialmente e não é específico da Américado Sul sendo o mais prevalente do Brasil (GALLINELLA et al., 2003, SLAVOV et al., 2012; SLAVOV et al., 2019 ).

Outro achado de extrema importância foi a presença de RNA do vírus da influenza A embolsas de sangue com DPD de Ribeirão Preto. A questão de transfusional da influenza foi sempre muito polemica. Por um lado, como o vírus causa uma fase 
viremica curta em conjunto de pandemias mundiais é de esperar que ele pode ser transmitido via transfusão de sangue. Que o vírus pode ser transmitido via transfusão foi relatado em um estudo feito em furões onde o inoculo de plasma viremico causou a morte dos animais (WANG et al., 2014). Por outro lado, não foi possível detecção de RNA do influenza A durante a pandemia da influenza H1N1 (gripe suína) em amostras pós-dação em doadores de sangue que tiveram infecção confirmada molecularmente após a doação, o que mostra que a viremia provavelmente é de carga extremamente baixa. Isso por um lado corrobora com os nossos dados, onde nós conseguimos achar apenas alguns fragmentos do genoma viral indicando que o vírus presente no sangue se encontra provavelmente em título muito baixo. Por outro lado, em comparação com o estudo supra citado, nós conseguimos identificar através da metageômica viral o vírus da influenza A em bolsa doada. Portanto, faz-se necessária uma investigação minuciosa para verificar a presença direta deste vírus e o risco de transmissão transfusional. Devido ao fato de ser uma zoonose e as altas taxas mutacionais em seu genoma, os vírus da influenza podem gerar novas cepas mutantes com características imprevisíveis (HILLEMAN, 2002; WIKRAMARATNA e GUPTA, 2009). Vários relatos descrevem a possível ameaça transfusional que o vírus da influenza A pode apresentar (ZOU, 2006). Portanto, essas características do Influenza A e caso a transmissão transfusional do vírus da influenza A sejam confirmados, demonstram que precisa deplanejamento rigoroso nos bancos de sangue durante épocas epidémicas como também demonstram os nossos resultados. Isso é agravado devido ao fato que a maioria dos pacientes transfundidos apresentam estado de imunosupressão e portanto uma possivel infecção com o vírus da influenza pode ter consequencias críticas. Porém interessantemente podemos descrever que nosso achado difere de outros estudos por não ser proveniente de uma pandemia ocorrendo no 
Brasil. Isso pode indicar que mesmo fora de grandes pandemias o vírus ainda pode se disseminar e ainda ser um possível risco para segurança transfusional.

Nós conseguimos detectar viroses emergentes com pouca informação na literatura da região amazónica no Brasil. Ao analisarmos amostras provenientes de doadores infectados com agentes virais parenterais (HIV, HBV, HCV, HTLV, sífilis e Chagas) nós conseguimos detectar vírus emergentes, dentre eles o HuGvK2. Os gemycircularvírus apresentam um grupo de vírus de DNA de fita simples, sem envelope sendo identificados pela primeira vez em fungos por volta de 2010 (YU et al., 2010). O genoma tem tamanho consideravelmente pequeno de 2,1 a 2,3 pb. Vírus geneticamente próximos já foram identificados nos mais diversos ambientes e materiais como em sangue e fezes de animais, esgoto bruto e tratado e matéria vegetal bem como animais diferentes (UCH et al., 2015). Porém apenas recentemente há relatos de sua presença em humanos. Diante de investigações de doenças com causas desconhecidas o vírus foi encontrado em amostras de sangue humano, tecido cerebral, líquido cefalorraquidiano e matéria fecal (LAMBERTO et al., 2014; PHAN et al., 2015). Curiosamente, estes vírus na literatura se encontram ligados a casos de doenças com causas desconhecidas. Há relatos recentes sobre $\mathrm{GcV}$ encontrado em amostras de sangue de um paciente com esclerose múltipla (LAMBERTO et al., 2014) e no líquido cefalorraquidiano (LCR) de pacientes com encefalite (PHAN et al., 2015), também há relatos do vírus no LCR de uma criança com encefalite na China (ZHOU et al., 2015). Outro caso interessante descrito na literatura contribui o $\mathrm{HuGvK} 2$, para desenvolvimento de doença respiratória aguda no trato inferior de uma mulher idosa (WANG et al., 2019). A identificação do DNA de HuGkV-2 em doadores de sangue sugere um risco hipotético de transmissão transfusional. No entanto, para ocorrer uma transmissão por transfusão de $H u G k V-2$, é necessária a confirmação do vírus infeccioso capaz de causar condição clínica no 
receptor, bem como uma cadeia de transmissão "doador-receptor" documentada. Nesse sentido, são necessários mais estudos para entender a biologia e o potencial transfusional do HuGkV-2.

Por outro lado, o DNA do HuGkV-2 foi identificado juntamente com infecções como HIV, HBV e que são transmitidas principalmente por contato sexual. Isso é semelhante aos dados obtidos para os vírus gemicirculares que foram detectados em pacientes infectados pelo HIV (MACERA et al., 2019) e uma doação de sangue positiva para HIV (UCH et al., 2015) que pode ser sugestivo para uma via de transmissão sexual do HuGkV-2. Dois dos doadores positivos de sangue revelaram comportamento de alto risco (foram classificados como buscadores de testes diagnósticos para HIV), o que também fornece evidências de que o HuGkV-2 pode ser transmitido parenteralmente. Além disso, a detecção de HuGvK-2 como uma coinfecção com HIV, HBV e sífilis pode sugerir que esse vírus possa atuar como um agente oportunista semelhante aos vírus gemicirculares (MACERA et al., 2019).

Neste estudo, obtemos também o genoma completo de MCPyV a partir de plasma pertencente a doadores de sangue de alto risco da Amazônia brasileira, com infecções comuns transmitidas por sangue como HBV, HCV, HIV, HTLV, doença de Chagas e sífilis. Desde a atribuição de propriedades tumorigênicas ao MCPyV como agente etiológico do carcinoma de Merkel, muitos estudos foram realizados em relação à sua patogênese e rotas de transmissão. Já foi detectada uma prevalência de DNA do MCPyVde 22\% no sangue de doadores de sangue saudáveis (PANCALDI et al., 2016; JIN et al., 2019) a baixas cargas virais, o que sugere que o vírus pode permanecer latente em um subconjunto de células sanguíneas (PANCALDI et al., 2016). No entanto, no nosso caso,o vírus foi detectado com alta cobertura (altas leituras virais no plasma), que é um indicador indireto de uma carga viral elevada e uma fase 
virêmica (isso foi também confirmado nas amostras individuais através de PCR). Um estudo metagenômico, avaliando o viroma do plasma preparado para aplicação hemoterapeutica, sugere que a presença de MCPyV era resultado da contaminação da pele (LAU et al., 2017) sendo que este agente viral é um dermatotrópico. No entanto, no nosso caso, o número de leituras virais foi muito alto e o DNA viral foi confirmado no plasma, o que sugere que o vírus estava com alta carga viral e provavelmente não era originário da pele. É mais provável que este seja um vírus reativado impulsionado pela condição imunológica do doador (infecção crônica por HBV). Se supusermos que houve um estado virêmico assintomático do $\mathrm{MCPyV}$, podemos sugerir que o vírus possa ser transmitido via transfusão de sangue.

Digno de nota, também fomos capazes de identificar a presença de diversas reads de sequências pertencentes ao vírus iridescente que infectam insetos naturalmente, incluindo mosquitos vetores de diversas doenças que podem causar DPD, como as febres arbovirais como a da Dengue, Zika, Febre Amarela, e Chikungunya entre outras. Não podemos excluir a possibilidade deste achado ser uma contaminação obtida durante o uso de reagentes de SNG em nossos experimentos, conforme discutido por outros estudos (ASPLUND et al., 2019). No entanto, não usamos nenhum reagente de laboratório que pudesse conter elementos genéticos ou partículas virais de origem de inseto. Outra possível explicação para a presença dessas sequências em nossas amostras é que, durante o surto, a população de mosquitos era muito abundante, permitindo a transmissão passiva de vírus de insetos para humanos. Além disso, algumas infecções por vírus iridescentes em humanos já foram descritas (WILLIAMS 2008) e também foi demonstrado que o vírus iridescente de invertebrados 6 pode induzir resposta imune antiviral dependente de interferon em células de mamíferos (AHLERS el al., 2016). No entanto, estudos mais específicos e aprofundados são necessários para investigar as possíveis interações entre 
vírus hospedeiros de mamíferos e invertebrados se essas interações realmente existirem.

Não sendo o foco deste estudo atual, porém também é valido destacar a presença abundante de diversos vírus considerados comensais nas amostras. Há centenas de estudos descrevendo como bactérias comensais influenciam na saúde e na doença do hospedeiro, porém o papel dos vírus comensais é pouco estudado e entendido. Alguns estudos desvendaram através da metagenômica viral em fezes que vírus comensais existentes no intestino em estado de disbiose podem causar doenças inflamatórias (LOPETUSO et al., 2016), entretanto falta ainda ligações fisiológicas suficientes para comprovar este fato. Porem um estudo publicado por Liu, L., e colegas (2019) demonstra que os vírus comensais são essenciais para a homeostase dos linfócitos intraepiteliais intestinais assim regulando de forma direta a imunidade. Porém o papel destes vírus em outras sistemas anatômicos como o plasma permanece obscuro e pouco estudado. Em nosso estudo encontramos uma gama diversidade desses vírus não patogênicos dentre eles podemos citar o pegivírus humano -1 ( $\mathrm{HPgV}-1$, anteriormente GBV-C) (SIMONS et al., 1995), um vírus comum que foi controversamente ligado ao atraso na progressão da AIDS no cenário de co-infecção pelo HIV-1 (SAHNI et al., 2014). Outro vírus constantemente achado e com abundância similar ao pegivírus humano são os vírus da família Anelloviridae. Muitos estudos associaram os anellovírus a algumas doenças, incluindo hepatite, esclerose múltipla, carcinomas hepatocelulares, infecções respiratórias, doenças do sangue e doenças autoimunes, mas nenhum deles foram capazes de confirmar que os anellovírus são o agente etiológico dessas doenças (GARCIA- ALVAREZ et al., 2013; MANCUSO et al., 2013; MASOURIDI-LEVRAT et al., 2016; SPANDOLE et al., 2015; TYSCHIK et al., 2017). Por outro lado, os anellovírus estão presentes em indivíduos saudáveis e são comumente detectados com alta prevalência emvários 
tipos de amostras, principalmente sangue (DE SOUZA et al., 2018). Estes dois vírus foram encontrados de forma frequente em nossas amostras, e podem ser inclusive utilizados como marcadores genéticos porém mais estudos são necessários para entender como sua interação com o hospedeiro pode influenciar em mecanismos mais complexos. 


\section{CONCLUSÃO}

Nossos resultados demonstram a importância da DPD e de investigar os possíveis agentes infeciosos que podem contaminar hemoderivadose que não são triados rotineiramente nos bancos de sangue. Também podemos salientar que essa investigação é de suma importância além de épocas de surtos, pois casos isolados ou importados podem prejudicar a segurança do processo transfusional. Achados como o vírus da dengue e influenza A fora da estação epidemiológica demonstram que estas doenças nãosão estritamente ligadas as épocas de surto e ocasionalmente podem afetar a transfusão de sangue. O nosso estudo é importante para possíveis notificações epidemiológicas e vigilância metagenômica podendo descrever o vasto panorama dos possíveis agente virais que podem comprometer a segurança transfusional. É importante ressaltar que atualmente não há possibilidade dos bancos de sangue para triar todos os agentes virais que possam ameaçar a segurança transfusional e, portanto, políticas públicas como educação dos doadores de sangue para relatar DPD devem ser reforçadas e são de suma importância para prevenção de viroses emergentes que podem ameaçar a segurança transfusional. De qualquer modo, o nosso estudo demonstra a alta capacidade do SNG eos métodos bioinformáticos para identificação de agentes virais com importância na medicina transfusional e aplicação na hemoterapia. 


\section{Referências}

ALKAN, C.; SAJJADIAN, S.; EICHLER, E. E. Limitations of next-generation genome sequence assembly. Nature methods, v. 8, n. 1, p. 61, 2011. https://doi.org/10.1038/nmeth.1527

ALTSCHUL, S. F. et al. Basic local alignment search tool. Journal of molecularbiology, v. 215, n. 3, p. 403-410, 1990. https://doi.org/10.1016/S00222836(05)80360-2

ANDERSON, M. J. et al. Human parvo virus, the cause of erythema infectiosum (fifth disease)?. Human parvo virus, the cause of erythema infectiosum (fifth disease)?, v.1, 1983.

ANDREWS, S. et al. FastQC: a quality control tool for high throughput sequence data. 2010. Disponível em: $<$ http://www.bioinformatics.babraham.ac.uk/projects/fastqc $>$

APPLEMAN, M. D. et al. Use of a questionnaire to identify potential blood donors at risk for infection with Trypanosoma cruzi. Transfusion, v. 33, n. 1, p. 61-64, 1993. https://doi.org/10.1046/j.1537-2995.1993.33193142312.x

ASPLUND, Maria et al. Contaminating viral sequences in high-throughput sequencing viromics: a linkage study of 700 sequencing libraries. Clinical Microbiology and Infection, v. 25, n. 10, p. 1277-1285, 2019. https://doi.org/10.1016/j.cmi.2019.04.028

BANKEVICH, A. et al. SPAdes: a new genome assembly algorithm and its applicationsto single-cell sequencing. Journal of computational biology, v. 19, n. 5, p. 455-477, 2012. https://doi.org/10.1089/cmb.2012.0021

BREITBART, M. et al. Genomic analysis of uncultured marine viral communities. Proceedings of the National Academy of Sciences, v. 99, n. 22, p. 14250-14255, 2002.https://doi.org/10.1073/pnas.202488399

BREITBART, M. et al. Metagenomic analyses of an uncultured viral community from human feces. Journal of bacteriology, v. 185, n. 20, p. 6220-6223, 2003.DOI: $10.1128 /$ JB.185.20.6220-6223.2003 
BOLGER, A. M.; LOHSE, M.; USADEL, B. Trimmomatic: a flexible trimmer for Illumina sequence data. Bioinformatics, v. 30, n. 15, p. 2114-2120, 2014. https://doi.org/10.1093/bioinformatics/btu170

BUCHFINK, B.; XIE, C.; HUSON, D. H. Fast and sensitive protein alignment using DIAMOND. Nature methods, v. 12, n. 1, p. 59-60, 2015. https://doi.org/10.1038/nmeth.3176

CHEN, S. et al. AfterQC: automatic filtering, trimming, error removing and quality control for fastq data. BMC bioinformatics, v. 18, n. 3, p. 91-100, 2017. https://doi.org/10.1186/s12859-017-1469-3

CHENG, V. C. C. et al. Japanese encephalitis virus transmitted via blood transfusion, Hong Kong, China. Emerging infectious diseases, v. 24, n. 1, p. 49, 2018. DOI: $10.3201 /$ eid2401.171297

CHIAL, H. DNA sequencing technologies key to the Human Genome Project. NatureEducation, v. 1, n. 1, p. 219, 2008.

CHUANG, V. W. M. et al. Review of dengue fever cases in Hong Kong during 1998 to2005. Hong Kong Medical Journal, v. 14, n. 3, p. 170, 2008.

CRICK, F. H. C. The origin of the genetic code. Journal of molecular biology, v. 38, n.3, p. 367-379, 1968. https://doi.org/10.1016/0022-2836(68)90392-6

DAYHOFF, M. O.; LEDLEY, R. S. Comprotein: a computer program to aid primary protein structure determination. In: Proceedings of the December 4-6, 1962, fall $\begin{array}{lllll}\text { joint computer } & \text { conference. } & 1962 . & \text { p. } & \text { 262-274. }\end{array}$ https://doi.org/10.1145/1461518.1461546

DRUMMOND, A. J.; RAMBAUT, A. BEAST: Bayesian evolutionary analysis by sampling trees. BMC evolutionary biology, v. 7, n. 1, p. 1-8, 2007. https://doi.org/10.1186/1471-2148-7-214

DE SOUZA, W. M. et al. Discovery of novel anelloviruses in small mammals expands the host range and diversity of the Anelloviridae. Virology, v. 514, p. 9-17, 2018. https://doi.org/10.1016/j.virol.2017.11.001 
EDMAN, P. et al. A method for the determination of the amino acid sequence in peptides. Arch. Biochem., v. 22, p. 475-476, 1949.

EID, J. et al. Real-time DNA sequencing from single polymerase molecules.

Science, v.323, n. 5910, p. 133-138, 2009. DOI: $10.1126 /$ science.1162986

SANTOS, Flávia LS et al. Vaso-occlusive crisis in a sickle cell patient after transfusiontransmitted dengue infection. Transfusion, v. 60, n. 9, p. 2139-2143, 2020.

https://doi.org/10.1111/trf.15968

FENG, H. et al. Clonal integration of a polyomavirus in human Merkel cell carcinoma.

Science, v. 319, n. 5866, p. 1096-1100, 2008. DOI: 10.1126/science.1152586

FLEISCHMANN, R. D. et al. Whole-genome random sequencing and assembly of Haemophilus influenzae Rd. Science, v. 269, n. 5223, p. 496-512, 1995. DOI: $\underline{10.1126 / \text { science. } 7542800}$

GALLINELLA, G. et al. B19 virus genome diversity: epidemiological and clinical correlations. Journal of clinical virology, v. 28, n. 1, p. 1-13, 2003. https://doi.org/10.1016/S1386-6532(03)00120-3

GARCIA-ALVAREZ, M. et al. Association of torque teno virus (TTV) and torque tenomini virus (TTMV) with liver disease among patients coinfected with human immunodeficiency virus and hepatitis $C$ virus. European journal of clinical microbiology \& infectious diseases, v. 32, n. 2, p. 289-297, 2013. https://doi.org/10.1007/s10096-012-1744-1

GAUTHIER, J. et al. A brief history of bioinformatics. Briefings in bioinformatics, v.20, n. 6, p. 1981-1996, 2019. https://doi.org/10.1093/bib/bby063

GHISALBERTI, G.; MASSEROLI, M.; TETTAMANTI, L. Quality controls in integrative approaches to detect errors and inconsistencies in biological databases. Journal of integrative bioinformatics, v. 7, n. 3, p. 52-64, 2010. https://doi.org/10.1515/jib-2010-119

GILL, S. R. et al. Metagenomic analysis of the human distal gut microbiome. science, v.312, n. 5778, p. 1355-1359, 2006. DOI: $10.1126 /$ science.1124234 
GOLDMAN, M. et al. The Canadian donor health assessment questionnaire: can it be improved?. Transfusion, v. 46, n. 12, p. 2169-2175, 2006. https://doi.org/10.1111/j.1537-2995.2006.01048.x

GORDON, D.; ABAJIAN, C.; GREEN, P. Consed: a graphical tool for sequencefinishing. Genome research, v. 8, n. 3, p. 195-202, 1998. DOI:

$\underline{10.1101 / \text { gr.8.3.195 }}$

HANDELSMAN, J. et al. Molecular biological access to the chemistry of unknown soilmicrobes: a new frontier for natural products. Chemistry \& biology, v. 5, n. 10, p. R245- R249, 1998. https://doi.org/10.1016/S1074-5521(98)90108-9

HILLEMAN, M. R. Realities and enigmas of human viral influenza: pathogenesis, epidemiology and control. Vaccine, v. 20, n. 25-26, p. 3068-3087, 2002. https://doi.org/10.1016/S0264-410X(02)00254-2

HOFFMANN, E. et al. Universal primer set for the full-length amplification of all influenza A viruses. Archives of virology, v. 146, n. 12, p. 2275-2289, 2001. https://doi.org/10.1007/s007050170002

JASKOLSKI, M.; DAUTER, Z.; WLODAWER, A. A brief history of macromolecular crystallography, illustrated by a family tree and its Nobel fruits. The FEBS journal, v. 281, n. 18, p. 3985-4009, 2014. https://doi.org/10.1111/febs.12796

JIN, H.T. et al. The frequency of Merkel cell polyomavirus in whole blood from immunocompetent and immunosuppressed patients with kidney disease and healthy donors. Microbial pathogenesis, v. 131, p. 75-80, 2019.

https://doi.org/10.1016/j.micpath.2019.03.020

KATOH, K. et al. MAFFT: a novel method for rapid multiple sequence alignment basedon fast Fourier transform. Nucleic acids research, v. 30, n. 14, p. 3059-3066, 2002. https://doi.org/10.1093/nar/gkf436

KURTZMAN, G. et al. Pure red-cell aplasia of 10 years' duration due to persistent parvovirus B19 infection and its cure with immunoglobulin therapy. New England Journal of Medicine, v. 321, n. 8, p. 519-523, $1989 . \quad$ DOI: $\underline{\text { 10.1056/NEJM198908243210807 }}$ 
LAMBERTO, I. et al. Mycovirus-like DNA virus sequences from cattle serum and human brain and serum samples from multiple sclerosis patients. Genome announcements, v. 2, n. 4, 2014. DOI: $10.1128 /$ genomeA.00848-14

LANDER, E. S. et al. Initial sequencing and analysis of the human genome. 2001. DOI: $\underline{10.1038 / 35057062}$

LAU, P. et al. Metagenomics analysis of red blood cell and fresh-frozen plasma units. Transfusion, v. 57, n. 7, p. 1787-1800, 2017. https://doi.org/10.1111/trf.14148

LEAMON, J. H. \& ROTHBERG, J. M. Cramming more sequencing reactions onto microreactor chips. Chemical Reviews, v. 107, n. 8, p. 3367-3376, 2007. https://doi.org/10.1021/cr068297s

LI, K. B.. ClustalW-MPI: ClustalW analysis using distributed and parallel computing. Bioinformatics, v. $19, \quad$ n. $12, \quad$ p. 1585-1586, 2003.https://doi.org/10.1093/bioinformatics/btg192

LI, J. Z. et al. Comparison of illumina and 454 deep sequencing in participants failing raltegravir-based antiretroviral therapy. PLoS One, v. 9, n. 3, p. e90485, 2014. https://doi.org/10.1371/journal.pone.0090485

LINNEN, J. M. et al. Dengue viremia in blood donors from Honduras, Brazil, and

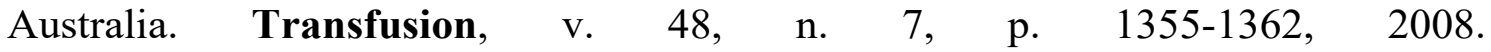
https://doi.org/10.1111/j.1537- 2995.2008.01772.x

LIPOWSKI, D. et al. A cluster of fatal tick-borne encephalitis virus infection in organ transplant setting. The Journal of infectious diseases, v. 215, n. 6, p. 896-901, 2017. https://doi.org/10.1093/infdis/jix040

LIU, K.; LINDER, C. R.; WARNOW, T. RAxML and FastTree: comparing two methods for large-scale maximum likelihood phylogeny estimation. PloS one, v. 6, n. 11, p. e27731, 2011. https://doi.org/10.1371/journal.pone.0027731

LIU, L. et al. Comparison of next-generation sequencing systems. BioMed researchinternational, v. 2012, 2012. DOI:10.1155/2012/251364 
LIU, L. et al. Commensal viruses maintain intestinal intraepithelial lymphocytes via noncanonical RIG-I signaling. Nature immunology, v. 20, n. 12, p. 1681-1691, 2019. https://doi.org/10.1038/s41590-019-0513-z

LOPETUSO, L. R. et al. Gut virome and inflammatory bowel disease.

Inflammatorybowel diseases, $\quad$ v. $22, \quad$ n. $7, \quad$ p. $1708-1712,2016$.

https://doi.org/10.1097/MIB.0000000000000807

MACERA, L. et al. Low prevalence of Gemycircularvirus DNA in immunocompetent and immunocompromised subjects. New Microbiol, v. 42, n. 2, p. 118-20, 2019.

MANCUSO, R. et al. Torque teno virus (TTV) in multiple sclerosis patients with different patterns of disease. Journal of medical virology, v. 85, n. 12, p. 2176-2183, 2013. https://doi.org/10.1002/jmv.23707

MANDE, S. S.; MOHAMMED, M. H.; GHOSH, T. Classification of metagenomic sequences: methods and challenges. Briefings in bioinformatics, v. 13, n. 6, p. 669-681, 2012. https://doi.org/10.1093/bib/bbs054

MARDIS, E. R. The impact of next-generation sequencing technology on genetics. $\begin{array}{llllllll}\text { Trends in } & \text { genetics, } & \text { v. 24, n. 3, p. 133-141, }\end{array}$ https://doi.org/10.1016/j.tig.2007.12.007

MARGULIES, M. et al. Genome sequencing in microfabricated high-density picolitrereactors. Nature, v. 437, n. 7057, p. 376-380, 2005.

https://doi.org/10.1038/nature03959

MARTIN, M. Cutadapt removes adapter sequences from high-throughput sequencingreads. EMBnet. journal, v. 17, n. 1, p. 10-12, 2011.

https://doi.org/10.14806/ej.17.1.200

MASOURIDI-LEVRAT, S. et al. Torque teno virus in patients undergoing allogeneic hematopoietic stem cell transplantation for hematological malignancies. Bone marrow transplantation, v. 51, n. 3, p. 440-442, 2016. https://doi.org/10.1038/bmt.2015.262 
MEDVEDEV, P. \& BRUDNO, M. Ab initio whole genome shotgun assembly with mated short reads. In: Annual International Conference on Research in Computational Molecular Biology. Springer, Berlin, Heidelberg, 2008. p. 50-64. https://doi.org/10.1007/978-3-540-78839-3_5

MERKEL, D. Docker: lightweight linux containers for consistent development and deployment. Linux journal, v. 2014, n. 239, p. 2, 2014.

MERRIMAN, B.; R\&D TEAM, Ion Torrent; ROTHBERG, J. M. Progress in ion torrentsemiconductor chip based sequencing. Electrophoresis, v. 33, n. 23, p. 33973417, 2012. https://doi.org/10.1002/elps.201200424

MOHAMMED, H. et al. Dengue virus in blood donations, Puerto Rico, 2005. Transfusion, v. 48, n. 7, p. 1348-1354, 2008. https://doi.org/10.1111/j.15372995.2008.01771.x

MOUSTAFA, A. et al. The blood DNA virome in 8,000 humans. PLoS pathogens, v.13, n. 3, p. e1006292, 2017.

https://doi.org/10.1371/journal.ppat.1006292

MYERS, E. W. et al. A whole-genome assembly of Drosophila. Science, v. 287, n. 5461,p. 2196-2204, 2000. DOI: 10.1126/science.287.5461.2196

NAGAHARU, K. et al. Persistent symptomatic parvovirus B19 infection with severe thrombocytopenia transmitted by red blood cell transfusion containing low parvovirus B19 DNA levels. Transfusion, v. 57, n. 6, p. 1414-1418, 2017. https://doi.org/10.1111/trf.14088

NIELSEN, H. B. et al. Identification and assembly of genomes and genetic elements in complex metagenomic samples without using reference genomes. Nature biotechnology, v. 32, n. 8, p. 822-828, 2014. https://doi.org/10.1038/nbt.2939

NGUYEN, L.T. et al. IQ-TREE: a fast and effective stochastic algorithm for estimatingmaximum-likelihood phylogenies. Molecular biology and evolution, v. 32, n. 1, p. 268- 274, 2015. https://doi.org/10.1093/molbev/msu300 
NOTREDAME, C.; HIGGINS, D. G.; HERINGA, J. T-Coffee: A novel method for fastand accurate multiple sequence alignment. Journal of molecular biology, v. 302, n. 1, p. 205-217, 2000. https://doi.org/10.1006/jmbi.2000.4042

OFFERGELD, R. \& HEIDEN, M. Selecting the right donors-still a challenge: development of a uniform donor questionnaire in Germany. Transfusion Medicine andHemotherapy, v. 44, n. 4, p. 255-262, 2017. https://doi.org/10.1159/000479193

PANCALDI, C. et al. Merkel cell polyomavirus DNA sequences in the buffy coats of healthy blood donors. Blood, The Journal of the American Society of Hematology, v.117, n. 26, p. 7099-7101, 2011. https://doi.org/10.1182/blood-2010$\underline{09-310557}$

PEALER, L. N. et al. Transmission of West Nile virus through blood transfusion in the United States in 2002. New England Journal of Medicine, v. 349, n. 13, p. 12361245,2003. DOI: $\underline{10.1056 / \text { NEJMoa030969 }}$

PHAN, T.G. et al. Small circular single stranded DNA viral genomes in unexplained cases of human encephalitis, diarrhea, and in untreated sewage. Virology, v. 482, p. 98104, 2015. https://doi.org/10.1016/j.virol.2015.03.011

PHAN, T. G. et al. The fecal virome of South and Central American children with diarrhea includes small circular DNA viral genomes of unknown origin. Archives of virology, v. 161, n. 4, p. 959-966, 2016. DOI: $10.1007 / \mathrm{s} 00705-016-2756-4$

QUEIROZ, R. B.; RODRIGUES, A. G.; GÓMEZ, A. T. Estudo comparativo entre as técnicas máxima verossimilhança gaussiana e redes neurais na classificação de imagensIR-MSS CBERS 1. I WorkComp Sul, v. 1, 2004.

RAMBAUT, A.; DRUMMOND, A. Molecular evolution, phylogenetics and epidemiology. FigTree v1, v. 3, 2007.

RAMBAUT, A. et al. Exploring the temporal structure of heterochronous sequences using TempEst (formerly Path-O-Gen). Virus evolution, v. 2, n. 1, p. vew007, 2016. https://doi.org/10.1093/ve/vew007

RAO, S. P.; MILLER, S. T.; COHEN, B. J. Transient aplastic crisis in patients with sickle cell disease: B19 parvovirus studies during a 7-year period. American Journal of 
$\begin{array}{llllllll}\text { Diseases of Children, } & \text { v. 146, n. 11, p. 1328-1330, }\end{array}$ DOI:10.1001/archpedi.1992.02160230086025

REID, D. M. et al. Human parvovirus-associated arthritis: a clinical and laboratory description. The Lancet, v. 325, n. 8426, p. 422-425, 1985. https://doi.org/10.1016/S0140-6736(85)91146-8

REUTER, J. A.; SPACEK, D. V.; SNYDER, M. P. High-throughput sequencing technologies. Molecular cell, v. 58, n. 4, p. 586-597, 2015. https://doi.org/10.1016/j.molcel.2015.05.004

RIBEIRO, G. O. et al. Detection and Characterization of Enterovirus B73 from a Childin Brazil. Viruses, v. 11, n. 1, p. 16, 2019. https://doi.org/10.3390/v11010016

ROSE, R. Challenges in the analysis of viral metagenomes. Virus Evolution, v. 2, n. 2,p. vew022, 2016. https://doi.org/10.1093/ve/vew022

SABINO, E. C. et al. Transfusion-transmitted dengue and associated clinical symptomsduring the 2012 epidemic in Brazil. The Journal of infectious diseases, v. 213, n. 5, p.694-702, 2016. https://doi.org/10.1093/infdis/jiv326

SAHNI, H. et al. GBV-C viremia and clinical events in advanced HIV infection.

Journalof Medical Virology, v. 86, n. 3, p. 426-432, 2014.

https://doi.org/10.1002/jmv.23845

SANGER, F. et al. Nucleotide sequence of bacteriophage $\varphi$ X174 DNA. Nature, v. 265,n. 5596, p. 687-695, 1977.

SANGER, F. \& THOMPSON, E. O. P. The amino-acid sequence in the glycyl chain of insulin. 1. The identification of lower peptides from partial hydrolysates. Biochemical Journal, v. 53, n. 3, p. 353-366, 1953.

SAUVAGE, V. et al. Viral metagenomics applied to blood donors and recipients at high risk for blood-borne infections. Blood Transfusion, v. 14, n. 5, p. 400, 2016. DOI: $\underline{10.2450 / 2016.0160-15}$ 
SAUVAGE, V. \& ELOIT, M. Viral metagenomics and blood safety. Transfusion Clinique et Biologique, v. 23, n. 1, p. 28-38, 2016. https://doi.org/10.1016/j.tracli.2015.12.002

SCHMIDT, H. A. et al. TREE-PUZZLE: maximum likelihood phylogenetic analysis using quartets and parallel computing. Bioinformatics, v. 18, n. 3, p. 502-504, 2002. https://doi.org/10.1093/bioinformatics/18.3.502

SCHMIEDER, R. \& EDWARDS, R. Fast identification and removal of sequence contamination from genomic and metagenomic datasets. PloS one, v. 6, n. 3, p. e17288,2011a. https://doi.org/10.1371/journal.pone.0017288

SCHMIEDER, R. \& EDWARDS, R. Quality control and preprocessing of metagenomic datasets. Bioinformatics, v. 27, n. 6, p. 863-864, $2011 \mathrm{~b}$. https://doi.org/10.1093/bioinformatics/btr026

SCHOW ALTER, R. M. et al. Merkel cell polyomavirus and two previously unknown polyomaviruses are chronically shed from human skin. Cell host \& microbe, v. 7, n. 6,p. 509-515, 2010. https://doi.org/10.1016/j.chom.2010.05.006

SHUDA, M. et al. T antigen mutations are a human tumor-specific signature for Merkelcell polyomavirus. Proceedings of the National Academy of Sciences, v. 105, n. 42, p.16272-16277, 2008. https://doi.org/10.1073/pnas.0806526105

SIMONS, J. N. et al. Isolation of novel virus-like sequences associated with humanhepatitis. Nature medicine, v. 1, n. 6, p. 564-569, 1995.

https://doi.org/10.1038/nm0695-

$\underline{564}$

SIQUEIRA, J. D. et al. Complex virome in feces from Amerindian children in isolated Amazonian villages. Nature communications, v. 9, n. 1, p. 1-11, 2018. https://doi.org/10.1038/s41467-018-06502-9

SPANDOLE, S. et al. Human anelloviruses: an update of molecular, epidemiological and clinical aspects. Archives of virology, v. 160, n. 4, p. 893-908, 2015. DOI $\underline{10.1007 / \mathrm{s} 00705-015-2363-9}$ 
ŠROLLER, V. et al. Seroprevalence rates of HPyV6, HPyV7, TSPyV, HPyV9, MWPyV and KIPyV polyomaviruses among the healthy blood donors. Journal of Medical Virology, v. 88, n. 7, p. 1254-1261, 2016. https://doi.org/10.1002/jmv.24440

STRAMER, S. L. et al. Emerging infectious disease agents and their potential threat to transfusion safety. Transfusion, v. 49, p. 1S-29S, 2009. https://doi.org/10.1111/j.1537- 2995.2009.02279.x

SUTTON, G. G. et al. TIGR Assembler: A new tool for assembling large shotgun sequencing projects. Genome Science and Technology, v. 1, n. 1, p. 9-19, 1995. https://doi.org/10.1089/gst.1995.1.9

SLAVOV, Svetoslav Nanev et al. Molecular and phylogenetic analyses of human Parvovirus B19 isolated from Brazilian patients with sickle cell disease and $\beta$-thalassemia major and healthy blood donors. Journal of medical virology, v. 84, n. 10, p. 1652-1665, 2012. https://doi.org/10.1002/jmv.23358

SLAVOV, Svetoslav N. et al. Parvovirus B19 seroprevalence, viral load, and genotype characterization in volunteer blood donors from southern Brazil. Journal of medical virology, v. 91, n. 7, p. 1224-1231, 2019. https://doi.org/10.1002/jmv.25453

TAMBYAH, P. A. et al. Dengue hemorrhagic fever transmitted by blood transfusion. New England Journal of Medicine, v. 359, n. 14, p. 1526-1527, 2008. DOI: $\underline{10.1056 / \mathrm{NEJMc0708673}}$

TATUSOVA, T. et al. NCBI prokaryotic genome annotation pipeline. Nucleic acidsresearch, v. 44, n. 14, p. 6614-6624, 2016. https://doi.org/10.1093/nar/gkw569

TSUJIMURA, M. et al. Human parvovirus B19 infection in blood donors. Vox sanguinis,v. 69 , n. 3, p. 206-212, 1995. https://doi.org/10.1111/j.14230410.1995.tb02595.x

TYSCHIK, E. A. et al. Transplacental transmission of torque teno virus. Virologyjournal, v. 14, n. 1, p. 92, 2017. https://doi.org/10.1186/s12985-017-0762$\underline{0}$

$\mathrm{UCH}$, R. et al. Divergent gemycircularvirus in HIV-positive blood, France.

Emerginginfectious diseases, v. 21, n. 11, p. 2096, 2015. DOI:

$\underline{10.3201 / \text { eid2111.150486 }}$ 
VUK, T. et al. Post-donation information management-contribution to the safety of transfusion treatment. Transfusion clinique et biologique: journal de la Societe francaise de transfusion sanguine, v. 26, n. 4, p. 353, 2019. DOI: 10.1016/j.tracli.2019.07.004

$\mathrm{XU}, \mathrm{M}$. et al. Metagenomics in pooled plasma, with identification of potential emerging infectious pathogens. Transfusion, v. 58, n. 3, p. 633-637, 2018. https://doi.org/10.1111/trf.14455

WALDVOGEL-ABRAMOWSKI, S. et al. Viral Metagenomics of Blood Donors and Blood-Derived Products Using Next-Generation Sequencing. Transfusion Medicine and Hemotherapy, v. 46, n. 2, p. 87-93, 2019. https://doi.org/10.1159/000499088

WANG, Z.; GERSTEIN, M.; SNYDER, M. RNA-Seq: a revolutionary tool for transcriptomics. Nature reviews genetics, v. 10, n. 1, p. 57-63, 2009. https://doi.org/10.1038/nrg2484

WANG, X. et al. Highly pathogenic avian influenza A virus (H5N1) can be transmittedin ferrets by transfusion. BMC infectious diseases, v. 14, n. 1, p. 192, 2014. https://doi.org/10.1186/1471-2334-14-192

WANG, J. et al. Gemykibivirus genome in lower respiratory tract of elderly woman with unexplained acute respiratory distress syndrome. Clinical Infectious Diseases, v. 69, n.5, p. 861-864, 2019. https://doi.org/10.1093/cid/ciz072

WIKRAMARATNA, P. S.; GUPTA, Sunetra. Influenza outbreaks. Cellular microbiology, v. 11, n. 7, p. 1016-1024, 2009. https://doi.org/10.1111/j.1462$\underline{5822.2009 .01320 . x}$

WILLIAMS, Trevor. Natural invertebrate hosts of iridoviruses (Iridoviridae). Neotropical entomology, v. 37, n. 6, p. 615-632, 2008. https://doi.org/10.1590/S1519566X2008000600001

WILKINSON, S. L. et al. Characteristics of post donation information donors and comparison with appropriately deferred donors. Transfusion, v. 51, n. 7, p. 15031510,2011. https://doi.org/10.1111/j.1537-2995.2010.03043.x 
WILLNER, D. et al. Metagenomic analysis of respiratory tract DNA viral communitiesin cystic fibrosis and non-cystic fibrosis individuals. PloS one, v. 4, n. 10, p. e7370, 2009. https://doi.org/10.1371/journal.pone.0007370

WOLD, B. \& MYERS, R. M. Sequence census methods for functional genomics.

Naturemethods, v. 5, n. 1, p. 19-21, 2008. https://doi.org/10.1038/nmeth1157

WOOD, D. E. \& SALZBERG, S. L. Kraken: ultrafast metagenomic sequence classification using exact alignments. Genome biology, v. 15, n. 3, p. 1-12, 2014. https://doi.org/10.1186/gb-2014-15-3-r46

YU, X. et al. A geminivirus-related DNA mycovirus that confers hypovirulence to a plant pathogenic fungus. Proceedings of the National Academy of Sciences, v. 107, n. 18, p.8387-8392, 2010. https://doi.org/10.1073/pnas.0913535107

ZHOU, C. et al. A novel gemycircularvirus in an unexplained case of child encephalitis. Virology journal, v. 12, n. 1, p. 1-4, 2015. https://doi.org/10.1186/s12985-015-0431-0

ZOU, S. Potential impact of pandemic influenza on blood safety and availability. Transfusion Medicine Reviews, v. 20, n. 3, p. 181-189, 2006. https://doi.org/10.1016/j.tmrv.2006.03.001 


\section{ARTIGOS PUBLICADOS}

DOS SANTOS BEZERRA, Rafael et al. Virome comparison of deferred blood donations obtained from different geographic regions in the Sao Paulo State, Brazil. Transfusion and Apheresis Science, p. 103106, 2021.

ADELINO, Talita Émile Ribeiro et al. Field and classroom initiatives for portable sequencebased monitoring of dengue virus in Brazil. Nature Communications, v. 12, n. 1, p. 1-12, 2021.

DOS SANTOS, Bezerra R. et al. Detection of Influenza A (H3N2) Virus RNA in Donated Blood. Emerging infectious diseases, v. 26, n. 7, 2020.

DOS SANTOS BEZERRA, Rafael et al. The novel coronavirus SARS-CoV-2: From a zoonotic infection to coronavirus disease 2019. Journal of medical virology, v. 92, n. 11, p. 2607-2615, 2020 .

BEZERRA, Rafael dos Santos et al. Viral metagenomics performed in patients with acute febrile syndrome during Toxoplasma gondii outbreak in south Brazil. Brazilian Journal of Infectious Diseases, v. 24, n. 3, p. 250-255, 2020.

BEZERRA, Rafael S. et al. Metagenomic identification of human Gemykibivirus-2 (HuGkV-2) in parenterally infected blood donors from the Brazilian Amazon. International Journal of Infectious Diseases, v. 98, p. 249-251, 2020.

SANTOS, Flávia LS et al. Vaso-occlusive crisis in a sickle cell patient after transfusiontransmitted dengue infection. Transfusion, v. 60, n. 9, p. 2139-2143, 2020.

DOS SANTOS BEZERRA, Rafael et al. Viral metagenomics in blood donations with postdonation illness reports from Brazil. Blood Transfusion, v. 19, n. 2, p. 93, 2021.

DOS SANTOS BEZERRA, Rafael et al. Molecular evolution pattern of Merkel cell polyomavirus identified by viral metagenomics in plasma of high-risk blood donors from the Brazilian Amazon. Infection, Genetics and Evolution, v. 85, p. 104563, 2020.

BEZERRA, Rafael dos Santos et al. Viral metagenomics in blood donors with post-donation diseases and negative tests for dengue and Zika viruses RNA detection during a major outbreak of arboviruses in Sao Paulo State in 2016. Revista do Instituto de Medicina Tropical de São Paulo, v. 62, 2020.

DOS SANTOS BEZERRA, Rafael et al. Molecular prevalence and genotypes of human pegivirus-1 (HPgV-1) and SENV-like viruses among multiply transfused patients with betathalassemia. Transfusion and Apheresis Science, v. 59, n. 2, p. 102697, 2020. 